\title{
The Ancient Egyptian Hieroglyphic Language Was Created by Sumerian Turks
}

\author{
Metin Gündüz \\ Retired Physician, Diplomate ABEM (American Board of Emergency Medicine), Izmir, Turkey \\ Email: metingunduz@sprintmail.com
}

How to cite this paper: Gündüz, M. (2017). The Ancient Egyptian Hieroglyphic Language Was Created by Sumerian Turks. Advances in Anthropology, 7, 197-250. https://doi.org/10.4236/aa.2017.74013

Received: August 2, 2017

Accepted: October 13, 2017

Published: October 16, 2017

Copyright (C) 2017 by author and Scientific Research Publishing Inc. This work is licensed under the Creative Commons Attribution International License (CC BY 4.0).

http://creativecommons.org/licenses/by/4.0/

\begin{abstract}
The "phonetic sound value of each and every hieroglyphic picture's expressed and intended meaning as a verb or as a noun by the creators of the ancient Egyptian hieroglyphic picture symbols, 'exactly matches', the same meaning" as well as the "first letter of the corresponding meaning of the Turkish word's first syllable" with the currently spoken dialects of the Turkish language. The exact intended sound value as well as the meaning of hieroglyphic pictures as nouns or verbs is individually and clearly expressed in the original hieroglyphic pictures. This includes the 30 hieroglyphic pictures of well-known consonants as well as some vowel sounds-of the language of the ancient Egyptians. There is no exception to this rule. Statistical and probabilistic certainty beyond any reasonable doubt proves the Turkish language connection. The hieroglyphic pictures match with 2 variables (the phonetic value and intended meaning). 1) Each hieroglyphic picture's known "phonetic value" through the Coptic language was proven by Champollion in 1822 (Champollion (1836), Robinson (2013)) who had well-known and unchallenged expertise in the Coptic language. 2) The phonetic value of each and every hieroglyphic picture matches with the corresponding meaning of the Turkish word's "first letter" or even entire letters of the "first syllable" in certain cases, consonant or vowel. The exact "intended meaning" of the hieroglyphic picture as a noun or as a verb matches with the Turkish dialects. This is the case for all 30 hieroglyphic pictures. No other spoken language can approach this match.
\end{abstract}

\section{Keywords}

The Origin of Sumerians, Pre-Dynastic Egypt, Archeologist Sir Flinders Petrie Excavations, Bio-Geography, DNA Evidence, Hieroglyphic Language Creation, Phonetic Values of Hieroglyphic Pictures, Coptic Language, Champollion, Current Turkish Dialects 


\section{Introduction}

When I wrote "The Origin of Sumerians" in November 2012 (Gunduz, 2012), I mentioned in the introduction that Dr. Anatole A. Klyosov had published many solid fundamental bio-geographic studies one after another (Klyosov, 2012) that are destined to be guiding foundations for further revelations regarding our common ancient human history. Those familiar with biogeography are likely aware of the significance of the findings and origin of the Y-haplogroup R1b mutation that arose 16,000 years ago. He called the offspring of the ancestors who originated this mutation as the Arbins bearers of R1b. The R1b Haplogroup is presumed to originate in south Siberia/Central Asia. There were approximately $8000-10,000$ years of migration, shuffling and regrouping since the original mutation of the R1b haplogroup of "Arbins" and their subclades. The Sumerians obviously belonged to the R1b haplogroup. Following the emergence of Neolithic agricultural societies resulting in permanent settlements and prolonged interactions and specializations throughout central Asia, "the original Sumerian homeland" became one of the Arbins regroupings throughout this period of history. Climate change forced them to make the maiden migration and resettle in the fertile lands of the Middle East between the Tigris and Euphrates Rivers around 4000 BC (Paleoclimatology, 2012; Houghton, et al., 1990) and they eventually moved further south on the banks of the Nile River in north-east Africa (Gunduz, 2012).

At the time of my writing, I knew more about Sumerian settlement in northeast Africa, but my subject matter was not Egypt, so I did not go into further detail.

Archeologist Sir Flinders Petrie excavated items from Pre-dynastic era Naqada II-Gerzian period, which spanned 3500 - 3200 BC. This culture was represented throughout Egypt and made the first marl pottery and metal-work seen in this period (Petrie, 1895).

What interested me the most about the Naqada II period was the existence of lapis lazuli stone at the burials of these migrants that Petrie had excavated and that are currently displayed at the Petrie Museum in London. These easily breakable and scratchable blue stones were considered "sacred" by the ancient Sumerians who took them to the grave. Underlying "faith value" and the strong religious belief of the ancient Sumerians were closely connected with these stones they believed in their protection throughout their lives. Lapis lazuli was highly valued and imported thousands of miles from the Hindu-Kush Mountains of present-day Afghanistan.

As mentioned in my original paper (Gunduz, 2012), the Sumerians were obsessed with their sacred blue metamorphic stone, the "lapis lazuli". To understand the scientific concepts behind the answer to the question of where the Sumerians originated 100 pages of excellent research by (Allessandro, 2011) is available at www.infn.it/thesis/PDF/getfile.php?filename=6327-Re-dottorato.pdf and required reading. To understand where the Sumerians originated, it is es- 
sential to know where they obtained lapis lazuli. This blue metamorphic stone has a "unique fingerprint" of trace elements that reflects its origin of creation on our planet, every mine has a different fingerprint of trace element ratios. In other words if one argues, that the lapis lazuli of Sumerians originated somewhere other than the Sar-i Sang mines of the Hindu Kush Mountains east of Turkmenistan, where Gonur Tepe and other Neolithic and Bronze Age settlements are located, it can easily be proven that the famous Standard of Ur found at the British Museum's lapis lazuli collection was actually mined from the Sar-i Sang lapis mines in Badakhshan, Afghanistan, (Moorey, 1999). The metamorphic blue stone has a "unique fingerprint" that is "analogous to mDNA or Y-DNA in the human genome" (Gunduz, 2012).

So what does it mean is the excavation of-lapis lazuli-as well as the archeological evidence collected by Petrie from Egypt's Pre-dynastic period specifically during the Naqada II era, was "indirect evidence" of the presence of Sumerians on the banks of the Nile River (Petrie, 1895).

The most significant, supporting evidence was revealed in 2010, when the Discovery Channel sponsored paternity testing of Tutankhamen and his father Akhenaton. Their DNA was found to be the R1b haplotype of the Y chromosome. The specific details of the results were inadvertently released but the data was later censured, presumably because of discussions involving Asian-African origin, but the truth was eventually revealed in scientific detail (Supplement Picture 1).

My recent interest in this issue re-surfaced in July 2017 due to a friend's Facebook post about ancient Egyptian linguistics and suspected a linguistic Turkish connection and posted a picture from the book Pharaohs and Kings: A Biblical Quest by David Rohl (1995). The subject was the ancient name Sh-a-l-m, that according to the author was the bygone name of the city of Jerusalem described in ancient hieroglyphs. His observation was correct that the "sh" sound in the first "hieroglyph" of the word had the same phonetic value as the Turkish syllable for "IŞ" in other words, the first syllable of the Turkish word "IŞIK" means light and the "sun" and "Sun God" concept of the ancient Egyptians.

Of course I had more scientific reasons than simple linguistic evidences surfacing here and there over the years, I have always believed the DNA evidence from 2010 and the archeological facts of the Sumerians true existence in Egypt since Sir Flinders Petrie's excavations in the $1880 \mathrm{~s}$, and archeological facts indicate the presence of Sumerians in Egypt (Petrie, 1895).

To me the linguistics is the branch of social sciences and the professionals involved in linguistic studies hardly ever agree unanimously on any hypothesis and/or common ground, simply because I have always believed that language is basically a software programming of the human brain gained after birth and influenced by mutual interactions and verbal communications.

But on this occasion my attention was particularly directed to the hieroglyphic depiction of the "individual picture" (Supplement Picture 2) of the "sh" sound 
rather than the obvious linguistic connection to the Sun God, in other words I was particularly interested in the mythology underlying the meaning of the pictures and how the ancient Egyptian religious priests who first established and construed the hieroglyphic pictures that would eventually correspond to the specific characteristic sound (phonetic value) of that picture and the visualization of that hieroglyphic picture later by some other educated individual with the knowledge of the same language will immediately recall and associate the same picture with the first syllable's consonant sound after visualizing the hieroglyphic picture.

The picture of the "sh" ("ş") phonetic value is the same sound created when the Turkish word "1̧̧ı" (light) is pronounced. The lotus flowers in the rectangular pool comprise the hieroglyphic picture that the initial creators of the hieroglyphs chose 4600-4700 years ago to give the phonetic value of "sh" ("ş") of the word "işı" in Turkish, which means "the light of the sun". The lotus flower is completely dependent on sun-light for its function and is important to Egyptian mythology; ancient Egyptian art depicted the lotus flower as a symbol of the sun, creation and rebirth and it was also a symbol of Upper Egypt.

As a symbol of the sun, the lotus flower was closely associated with Atum-Ra, the Sun god, and later with Nefertum the lotus god of perfume. Lotus flowers, open in the morning and close at night, symbolizing rebirth and regeneration. The lotus flower also symbolized the deceased upon entering the underworld and the process of rebirth, regeneration, and reincarnation (Lotus Symbol, 2017).

There is a clear connection between the phonetic value of the hieroglyphic picture and the "first consonant and/or vowel letter" of the nouns or verbs of the corresponding same meaning of the Turkish language words. The hieroglyphic pictures "phonetic values" exactly match "the first letter" of the corresponding Turkish words that has the same intended meaning of the hieroglyphic picture.

A long supplement list below has a detailed explanation and references for each of the 30 hieroglyphic consonants and vowels pictures and their individual specific phonetic value as agreed upon by mainstream Egyptologists and linguists. The Supplement includes the corresponding Turkish meaning of the individual hieroglyphic pictures intended as a noun or as a verb and their well known and accepted phonetic values thanks to Champollion's Coptic language expertise and the corresponding same meaning of the Turkish noun's or verb's "first consonant or vowel letter". The corresponding Turkish nouns and verbs exactly matches the ancient Egyptian hieroglyphics intended meaning and the phonetic value completely (2 variables matching in each and every hieroglyphic sign, intended meaning and the phonetic value matches with the first letter or the entire first syllable of the corresponding Turkish word in certain hieroglyphic signs).

How is this possible?

First, and the obvious reason is, we are comparing the expressed meaning of the hieroglyphic pictures. The ancient "artists" created hieroglyphics for the 
purpose of communication, and to duplicate the initial visual impression of the creator for the later observers of the picture. In between people who had common language and communication with each other as well as same mythological belief system 5000 years ago.

Second, and most importantly the phonetic values of each and every hieroglyphic picture corresponding to the individual consonant or vowel value, were preserved-as it was-without change remarkably up to our time, thanks to the language expertise of Jean-François Champollion. There was a smooth transition of the phonetic values of each original hieroglyphic picture from demotic Egyptian and to the Coptic language. The vowel sound values were not pictured in between the consonant hieroglyph pictures but the necessary sound values of these presumed vowels appeared in people's minds as they read the familiar group of consonant hieroglyphic symbols.

Undoubtedly the spoken language was well known by educated speakers of ancient Egyptian language. I have to point out this fact as well, it is not the cuneiform language we are dealing here, that the Mesopotamian Sumerians adopted, obviously has no meaningful picture to interpret or closely associate with the phonetic value meaning. In addition it evolved to the Akkadian and later to Assyrian cuneiform languages but the sound values were lost long ago.

But for the ancient Egyptian hieroglyphs, the story is completely different and the explanation is very clear historically and linguistically. The scholar, philologist Jean-François Champollion with his expertise in Coptic language explained it correctly when he deciphered the hieroglyphs. The ancient scripts of the hieroglyphics were replaced with "Coptic", a script consisting of 24 letters from the Greek alphabet supplemented by 6 demotic characters used for original Egyptian sounds not expressed in Greek language. The ancient Egyptian language continued to be spoken and evolved into what became known as the "Coptic" language, but in due course both the Coptic language and script were displaced by the spread of Arabic in the eleventh century. The final linguistic link to Egypt's ancient kingdoms was broken, and the knowledge required to read the history of the pharaohs was lost. Although the Coptic language, a descendant of ancient Egyptian, had ceased to be living language, it still existed in a fossilized form in the liturgy of the Christian Coptic Church. Champollion had learned Coptic as a teenager (Champollion, 1822; The Decipherment of Rosetta Stone, 1822) and was so fluent that he used it to record entries in his journal. However, he had not previously considered that Coptic might also be the language of hieroglyphs, and discovered later to his surprise that it was indeed the language of the hieroglyphs. So we have the exact or near exact-phonetic values of original hieroglyphic pictures thanks to Champollion's linguistic expertise in Coptic (Champollion, 1822; The Decipherment of Rosetta Stone, 1822).

That is exactly the underlying reason why we can "directly" compare the original hieroglyphic picture-intentions, motivations, and communication methods and the true phonetic values of each hieroglyphic sign with the currently 
spoken Turkish dialects. We know the phonetic values of each original hieroglyphic picture' due to Coptic preservation of the original phonetic values of the hieroglyphic language supplementing Greek with 6 demotic characters used for original Egyptian sounds not expressed in the Greek language.

I propose making phonetic value corrections for the "ü" from "u" and "ö" from "o" for some of the original ancient Egyptian hieroglyphic signs, assuming the currently spoken Turkish dialects and first sound of the verb and noun have been same all along.

The 30 hieroglyphic pictures and their known "phonetic values" from the Coptic that "exactly match" the currently spoken dialects of Turkish nouns or verbs and exact meaning of the pictures as well as the "first letter of the first syllable" even "first 2 and 3 letters of the entire first syllable" of the corresponding Turkish nouns and verbs as originally intended by the creators of hieroglyphic language are individually self-explanatory. They are listed in the Supplement section.

Little linguistic knowledge of the Turkish language is needed in addition to common sense and logic.

\section{Discussion}

First, I am a firm believer in the fundamental principle, that any extraordinary scientific claim, requires extraordinary evidence. And that was the only reason at my original paper published in November 2012 (Gunduz, 2012) "The Origin of Sumerians", I have never argued one way or other about the identity of those called Sumerians who were forced by the climate change to migrate to the Euphrates, Tigris and Nile Rivers around 4000 BC. Although it was clear that their original homeland was the early Bronze Age settlements of Anau, Gonur and others around the Kopet Dag Mountains of Turkmenistan.

At the time I was very well aware of the firmly established archeological evidence by Petrie's excavations of the Naqada II (Gerzian) periods that spanned 3500 - 3200 BC and later periods of Naqada III, (Petrie, 1895) which was the last phase of the Naqada culture of ancient Egyptian prehistory from 3200 to 3000 BC. It is the period during which the state formation occurred (Naqada Culture (2017); Naqada III Culture (2017)).

I was also well aware of the Discovery Channel sponsored research "King Tut Unwrapped" on February 17, 2010, in which Pharaoh Tutankhamen's paternity was confirmed through DNA testing linking him to his father Akhenaten and grandfather Amenhotep III. The computer screen-shots were filmed revealing "short tandem repeat" (STR) values, which are the DNA codes of the paternal Y-chromosome haplotypes, fifteen of these STR values were readable and when the values were entered into Whit Athey's Haplogroup Predictor program (Whit Athey, 2017), they clearly established the Y-DNA score of 99.9\% R1b (Arbin), which is clearly Sumerian (Supplement Picture 1). After this rather unexpected information was released publicly by the Discovery Channel, African and Asian 
origin arguments surfaced and the Supreme Council of Antiquities (SCA) Department of the Egyptian Ministry of Culture censured the details of the data. Scientifically speaking, who ever argues against the claim that the Egyptian hieroglyphic language was created by the Sumerian Turks has to answer the question of "censoring" the Scientific data on the Sumerian origin of the Eighteenth Dynasty of Egypt after it was already public knowledge.

I knew all of this in 2012 when I wrote "The Origin of Sumerians" but at that time I did not have the "extraordinary" evidence to proceed until now, which I surely have without any reasonable doubt in my mind, with statistical probability of absolute certainty.

Absolute certainty is based on the hieroglyphic pictures created roughly 4600 years ago by ancient Egyptian priests, the phonetic values of each consonant and vowel sound were transmitted unaltered from the hieroglyphic pictures to demotic Egyptian and ultimately to the Coptic language in Greek letters with the supplementation of 6 additional demotic symbols corresponding to the original ancient hieroglyphic pictures. This smooth transmission of the phonetic values of the ancient Egyptian hieroglyphs is unique from a historical perspective.

Scholar, philologist Jean-François Champollion (Champollion, 1822; The Decipherment of Rosetta Stone, 1822; Budge, 1905; Sharp, 1871), had learned Coptic as a teenager, and was so fluent that he used it to record entries in his journal. This was the most remarkable and fortunate chain of events in the evolution and smooth unaltered transmission of the original hieroglyphic phonetic values to the present. There is no argument that currently spoken dialects of Turkish changed over time, but the phonetic values of the nouns and verbs and particularly the first syllable's initial sound value most probably maintained its value over time, although the rest of the syllables might have changed. I am not claiming that the dialect of spoken Turkish's phonetic values are similar to 4600 years ago, of course they have changed, but it is still recognizable with their similar phonetic values. As a matter of fact retrospectively I was so surprised to see, the " $\ddot{o}$ " and "i" and " $\ddot{\mathrm{u}}$ " Turkish sound values were very likely the same 4600 years ago, based on the specific and obvious number 2 and 3 based hieroglyphic picture designation and usage as the numbers for the same initial syllable' phonetic values, "iki" means "two", and "üç" means "three", (2 and 3), and the "i" and "ü" designation of phonetic values of the hieroglyphics as well as the "ö" designation reflect the perfect resourcefulness and imagination of the original creators of hieroglyphic Egyptian language.

Statistically speaking, this perfect match of the hieroglyphic pictures' phonetic values as confirmed through the Coptic language by Champollion (Champollion, 1822; The Decipherment of Rosetta Stone, 1822), as well as the Turkish meaning of each hieroglyphic picture with spoken dialects of the Turkish language, is unprecedented and in the range of absolute certainty.

For example, the hieroglyphic picture designated as "folded cloth" has the "Ss" consonant phonetic value of " $\mathrm{s}$ " in Turkish is "Sermek" meaning hanging the 
cloth (Supplement Picture 21). The "Bb" consonant phonetic value designation "leg" meaning "Bacak "in Turkish dialects (Supplement Picture 11). The "Aa" phonetic value designation vulture means "Akbaba" in Turkish (Supplement Picture 9). The "Dd" phonetic value designation is "open hand "picture extending to touch means "Değmek or Dokunmak" in Turkish dialects both verbs start with "D" sound (Supplement Picture 46). The "Ss" phonetic value designation hieroglyphic picture of "bolt" means "Sürgü" in Turkish dialects (Supplement Picture 25). The "Nn" phonetic value designation of "wavy river" hieroglyphic sign means "Nehir or Nahr" in Turkish dialects (Supplement Picture 20). The "Hh" phonetic value designation "wick" means "Halat" in Turkish (Supplement Picture 13). The "Jj" phonetic value designation "cobra snake" means "Jilan" in the Kazak Turkish dialect and "Jil" in the Kyrgyz Turkish dialect (Supplement Picture 17).

And the significant one is the ancient hieroglyphic picture that has the phonetic value of "Gg" and the archeologists and linguists thought that this picture was "jar holder", of course the picture has nothing to do with a "jar holder" in any shape or form at (Supplement Picture 3) I included ancient Egyptian "jar holders" as well as the pictures of the "original hieroglyphic carvings" of this sign that has "Gg" phonetic value. As you can imagine the jar holder "should have a flat stable base" not "curved" as clearly depicted at the original carvings and wall paintings. It is a "baby crib", a baby is put to sleep by rocking the crib, so the bottom is curved and the matching Turkish names are "Gundag (Azeri Turkish) or "Gundağ (Turkmenistan)" dialects, Turkmenistan where they originally migrated $4000 \mathrm{BC}$ as I had pointed out at "The Origin of Sumerians" (Gunduz, 2012).

Very interesting one is the scarab (dung beetle) which has phonetic value designated as "kheper", the Turkish pronunciation "kıpır kıpır "is the verb used for something "moving constantly in an unstoppable manner", which is the exact description of a "dung beetle"(scarab) in constant action (Supplement Picture 28).

The 30 ancient hieroglyphic signs are perfectly matched to the Turkish dialects for both the intended and expressed meaning and the first letter of the first syllable's phonetic value as a verb or noun. Some of the Hieroglyphic symbols phonetic values like "Ankh", "Neb", "Nefer", "Tuth" first two or first three letters of the first syllable of the corresponding meaning of the Turkish word perfectly matches (Supplement Picture 47, Picture 51, Picture 50, Picture 63).

I did not mathematically calculate the obvious and absolute certainty or put a significance value on this unprecedented perfect match. There are detailed pictured explanations for each hieroglyphic sign in the Supplement.

The correlation list goes on and on and the Supplement section's pictures and explanations will reveal the whole picture of this obvious linguistic close correlation and evidence.

Supplement section includes 80 different hieroglyphic signs, words, expres- 
sions and samples from Gardiner's sign list (Bill, 2013), Egyptian hieroglyphic book (Mark \& Bill, 1998), the difficult hieroglyphic words that experts at a convention in Egypt tried to decipher the "true meaning of the words" written at Louvre Stele or Irtysen Stele 2000 BC (Supplement Pictures 43-45), I suggested solutions to those problems they face through Turkish meaning of the ancient group of hieroglyphic picture words meaning according to the very close or similar pronunciations in Turkish, explained in detail as well as the phonetic meaning interpretation errors made in some of the readings of the hieroglyphic words based on the "phonetic values of the signs". At the Supplement section I also highlighted the importance of this revelation.

"Correct reading of the entire hieroglyphs in Egyptian history" will be possible experts and scholars will get the benefit of "full acceptance of Sumerian Turks creation of hieroglyphic language" by interpreting hieroglyphic words with the help of Turkish dialects of our time "rather than guessing". Champollion spoke so many languages 14 of them but unfortunately he did not know Turkish. If he did he would have figured it out on the spot (Champollion, 1822; The Decipherment of Rosetta Stone, 1822).

At the (Supplement Picture 79) experts did not specify what is in the jar beer or wine "in fact it was written already with three parallel lines which means 3 (and Ancient Egyptians used it as a phonetic value of "Ü" of "ÜÇ" means number three in Turkish", which corresponds to "Üzüm" meaning grape so the jar describes the Wine bottle.

At the (Supplement Picture 51, Pictures 78-80), I explained interesting hieroglyphic picture "the trachea and the heart" with phonetic value "nefer" and how 3 different words with 3 different meanings "Soldier-Breath-Beautiful" created from the same sign's phonetic value, by using 3 different "determinants"-determinants are additional pictures or signs with no phonetic value and used by ancient scribes to express their true intentions with the hieroglyphic pictures, what they mean-these are Turkish words Nefer-Nefes-Nefis (Soldier-Breath-Beautiful) all used by the ancient Egyptians, these words thought to be Arabic language origin but in reality Arabic language originated during early iron age around $1200 \mathrm{BC}$ and we have the archeological evidence of "nefer" hieroglyphic picture sign used for its phonetic value back in 2600 BC with the "determinants" in order to explain the intent of the ancient scribes, so the "root words" of these Nefer-Nefes-Nefis were Sumerian Turkish (Supplement Picture 51, Pictures 78-80).

The official Turkish Dialects web page from the Turkish Language Association (Türk Dil Kurumu was used as the reference for the Turkish dialects (Türk Dil Kurumu, 2017)).

\section{Summary and Conclusion}

It is a big revelation I am certainly well aware of that fact, it is a challenge for the people of Egyptology around the world who have believed otherwise or do not 
want the truth revealed for some reason or other and prefer to continue the current belief system and understanding as status quo but scientifically speaking this was the ultimate and the only outcome, as I had pointed out earlier well known and revealed paternity DNA evidence in detail as well as archeological evidences of Sumerian's long established existence by the Nile River since 3500 BC Naqada II period, it was just a matter of time and the future bio-geographic studies on DNA samples of the pharaohs throughout ancient Egypt might certainly clarify this matter once for all, if it is done freely and if we approach the issues scientifically rather than political or racial bias and without concealing the scientific evidence and being scientifically neutral in order to learn the truth for our common history and come to the terms with the reality that the human migration which has been quite natural and usual and it was absolutely necessary for the survival of our species in the past and present as well, as a matter of fact we are all migrants at one time in our ancient past that is for sure.

\section{References}

Allessandro, R. (2011). Ion and Electron Microscopy for the Characterization of Materials of Archaeological, Historical and Artistic Interest: Determination of the Provenance of lapis Lazuli Used for Glyptic Art. Ph.D. Thesis, Torino: Università Degli Studi di Torino. www.infn.it/thesis/PDF/getfile.php?filename=6327-Re-dottorato.pdf

Bill, P. (2013). Hieroglyphic Sign List Based on the Work of Alan Gardiner Museum. Littleton: Tours Press.

Budge, E. A. W. (1905). The Nile, Notes for Travelers in Egypt ( $9^{\text {th }}$ ed., pp. 199-211). London: Thos. http://www.sacred-texts.com/egy/trs/trs07.htm

Champollion, J. F. (1822).

https://en.wikipedia.org/wiki/Jean-Fran\%C3\%A7ois_Champollion

Champollion, J.-F. (1836). Grammaire Egyptienne ou Principes Generaux, Typographie De Firmin Didot Freres, Paris. https://archive.org/stream/Grammairegyptiennechampollion1836\#page/n0/mode/2up

Gunduz, M. (2012). The Origin of the Sumerians. http://www.scirp.org/Journal/PaperInformation.aspx?PaperID=24588

Klyosov, A. (2012). Ancient History of Arbins, Bearers of Haplogroup R1b, from CENTRAL Asia to Europe, 16,000 to 1500 Years before Present. Advances in Anthropology, 2, 49-56. https://doi.org/10.4236/aa.2012.22010

Lotus Symbol (2017). http://www.landofpyramids.org/lotus-symbol.htm

Mark, C., \& Bill, M. (1998). How to Read Egyptian Hieroglyphs. British Museum Press.

Moorey, P. R. (1999). Ancient Mesopotamian Materials and Industries: The Archaeological Evidence. Warsaw, IA: Eisenbrauns.

Naqada Culture (2017). https://en.wikipedia.org/wiki/Naqada_culture

Naqada III Culture (2017). https://en.wikipedia.org/wiki/Naqada_III

Paleoclimatology (2012). Study of Ancient Climates. http://www.lakepowell.net/sciencecenter/paleoclimate.htm

Petrie, F. (1895). Naqada and Ballas 1895 Excavations by Flinders Petrie, the Petrie Museum of Egyptian Archaeology Characters and Collections. UCL Press. http://brittlebooks.library.illinois.edu/brittlebooks_open/Books2009-08/petrwi0001naq 
bal/petrwi0001naqbal.pdf

http://discovery.ucl.ac.uk/1468795/4/The_Petrie_Museum_of_Egyptian_Archaeology.pdf

Robinson, A. (2013). Cracking the Egyptian Code: The Revolutionary Life of Jean-Francois Champollion, Thames \& Hudson.

Sharp, S. (1871). The Rosetta Stone in Hieroglyphics and Greek Translations.

http://www.info-quest.org/documents/PDF/Rosetta-Stone.pdf

The Decipherment of Rosetta Stone (1822).

https://circa71.wordpress.com/tag/hieroglyphs/

https://www.greathistorians.com/en/jean-francois-champollion

Türk Dil Kurumu (2017). Turkish Dialects Official Webpage.

http://www.tdk.gov.tr/index.php?option=com_lehceler\&arama=lehceler\&guid=TDK.L HC.59806e6fe90526.22133333

Whit Athey (2017). Y Haplogroup Prediction from Y-STR Values. http://www.hprg.com/hapest5/ 


\section{Supplement}

Over 80 detailed picture explanations and original hieroglyphic pictures and additional references, importance of this finding explained in detail with hieroglyphic word samples

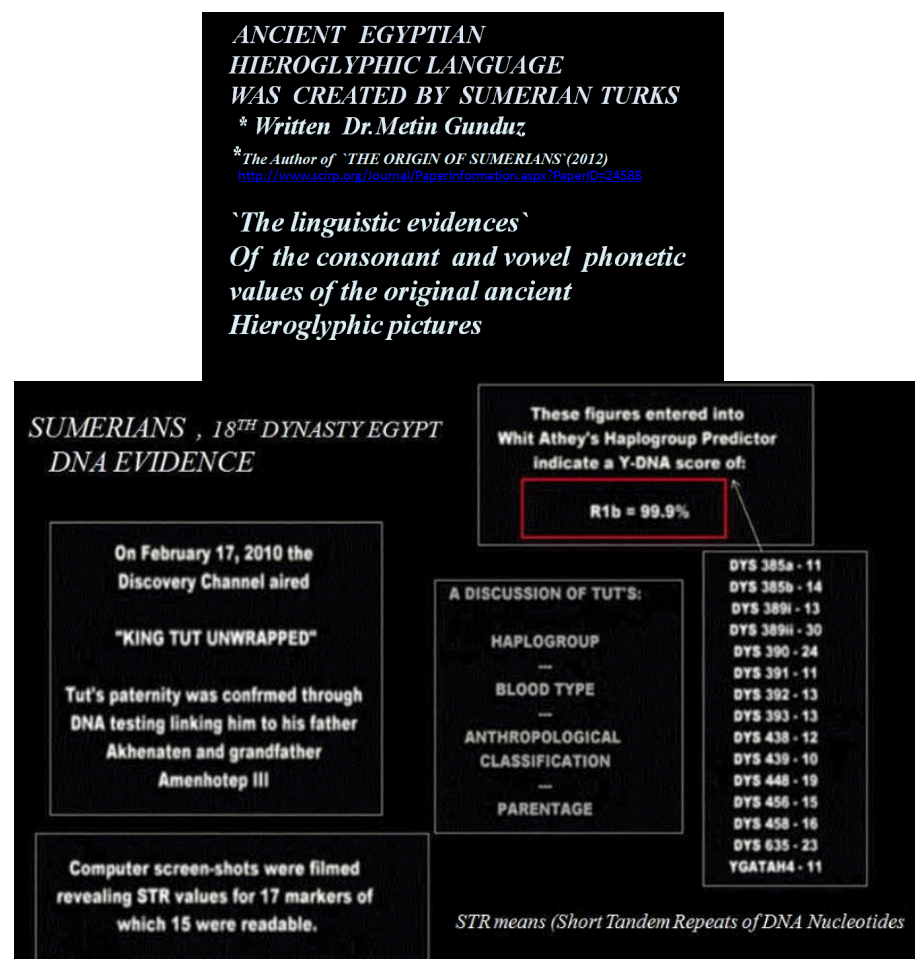

Picture 1. DNA Testing results of Pharaoh Tutankhamen, specific STR (Short Tandem Repeats) which reveal \% 99.9 R1b Y-DNA Haplogroup by Whit Athey's Haplogroup Predictor.

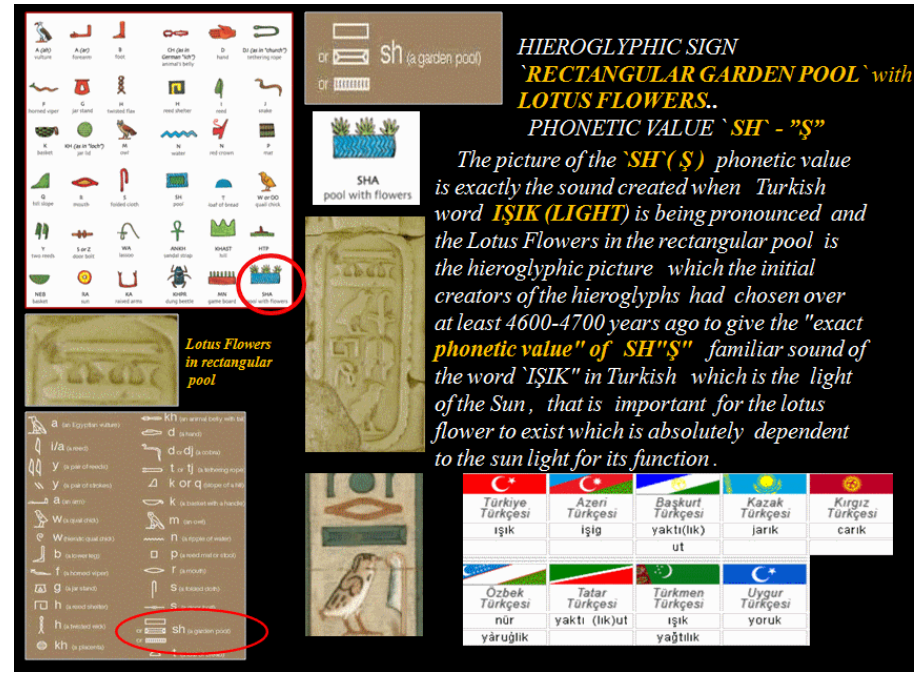

Picture 2. http://tureng.com/tr/turkce-ingilizce/\%C4\%B1\%C5\%9F\%C4\%B1k Işık Turkish Dialects official web page for TÜRK DİL KURUMU

http://www.tdk.gov.tr/index.php?option=com_lehceler\&arama=lehceler\&guid=TDK.LH C.59806e6fe90526.22133333. 


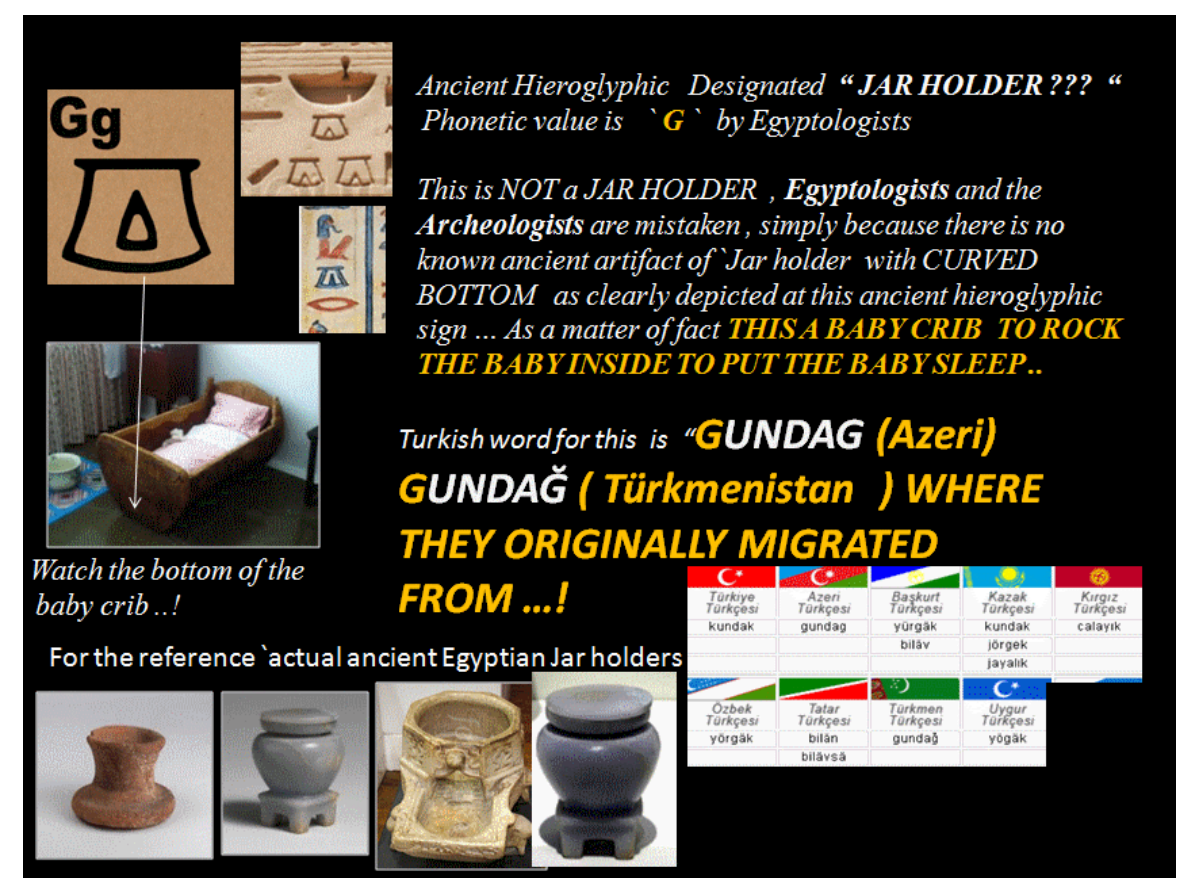

Picture 3. Turkish Dialects official web page for TÜRK DİL KURUMU

http://www.tdk.gov.tr/index.php?option=com_lehceler\&arama=lehceler\&guid=TDK.LH C.59806e6fe90526.22133333.

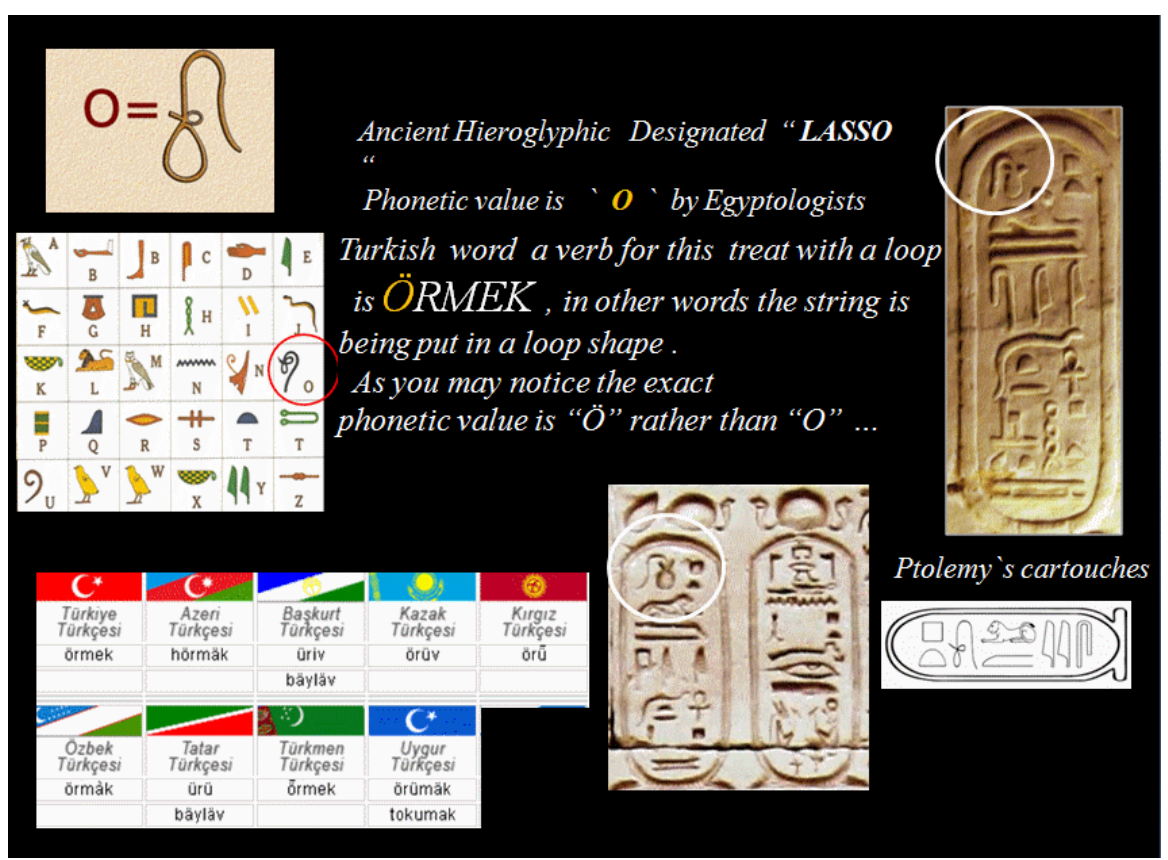

Picture 4. http://tureng.com/tr/turkce-ingilizce/\%C3\%B6rmek Örmek Turkish Dialects official web page for TÜRK DİL KURUMU

http://www.tdk.gov.tr/index.php?option=com_lehceler\&arama=lehceler\&guid=TDK.LH C.59806e6fe90526.22133333. 


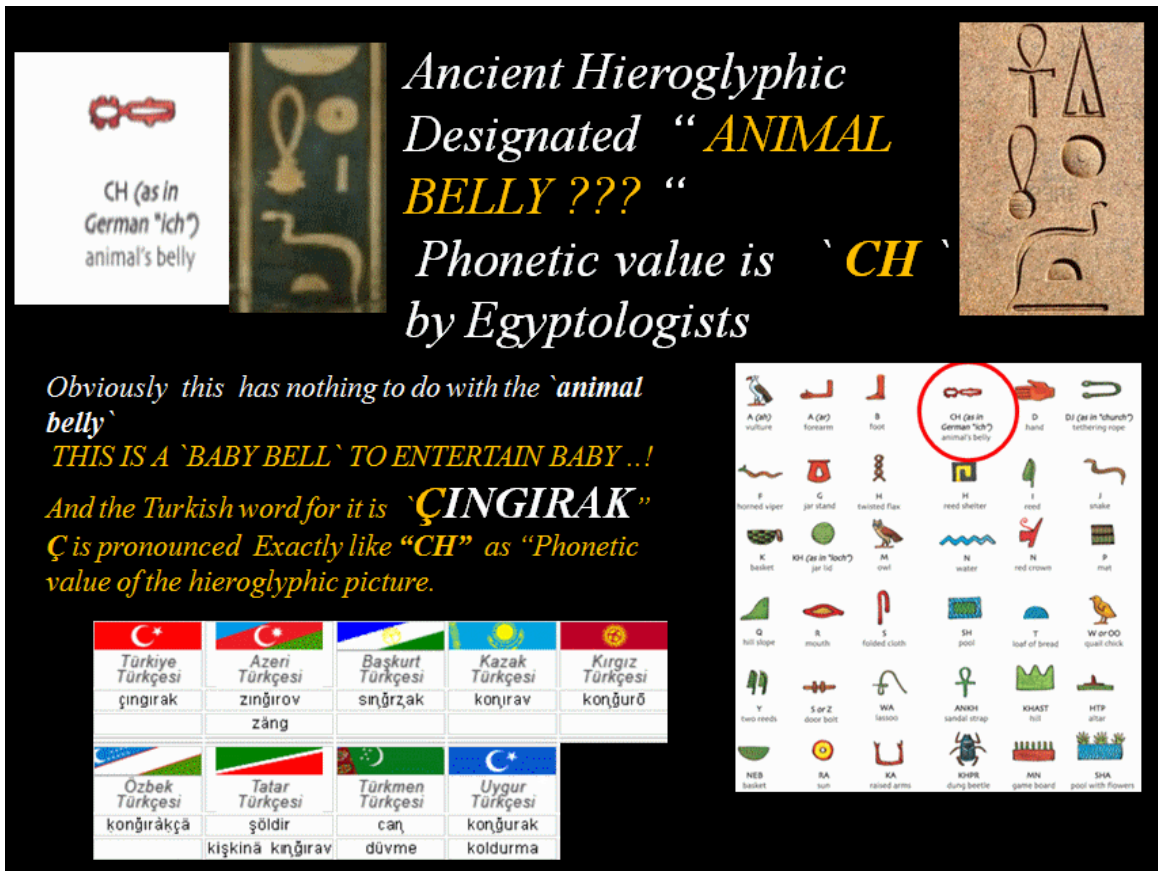

Picture 5. http://tureng.com/tr/turkce-ingilizce/\%C3\%A7\%C4\%B1ng\%C4\%B1rak Çıngırak. Turkish Dialects official web page for TÜRK DİL KURUMU

http://www.tdk.gov.tr/index.php?option=com_lehceler\&arama=lehceler\&guid=TDK.LH C.59806e6fe90526.22133333.

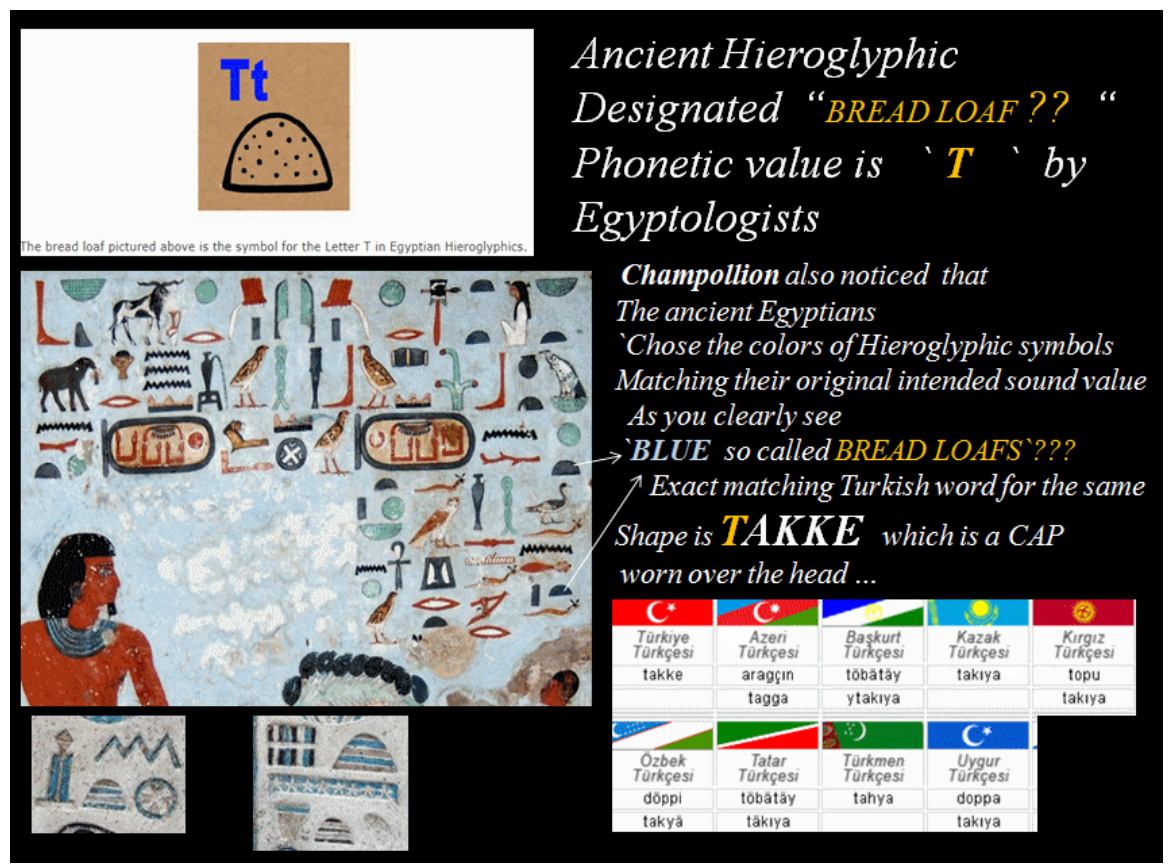

Picture 6. http://tureng.com/tr/turkce-ingilizce/takke Takke Turkish Dialects official web page for TÜRK DİL KURUMU http://www.tdk.gov.tr/index.php?option=com_lehceler\&arama=lehceler\&guid=TDK.LH C.59806e6fe90526.22133333. 


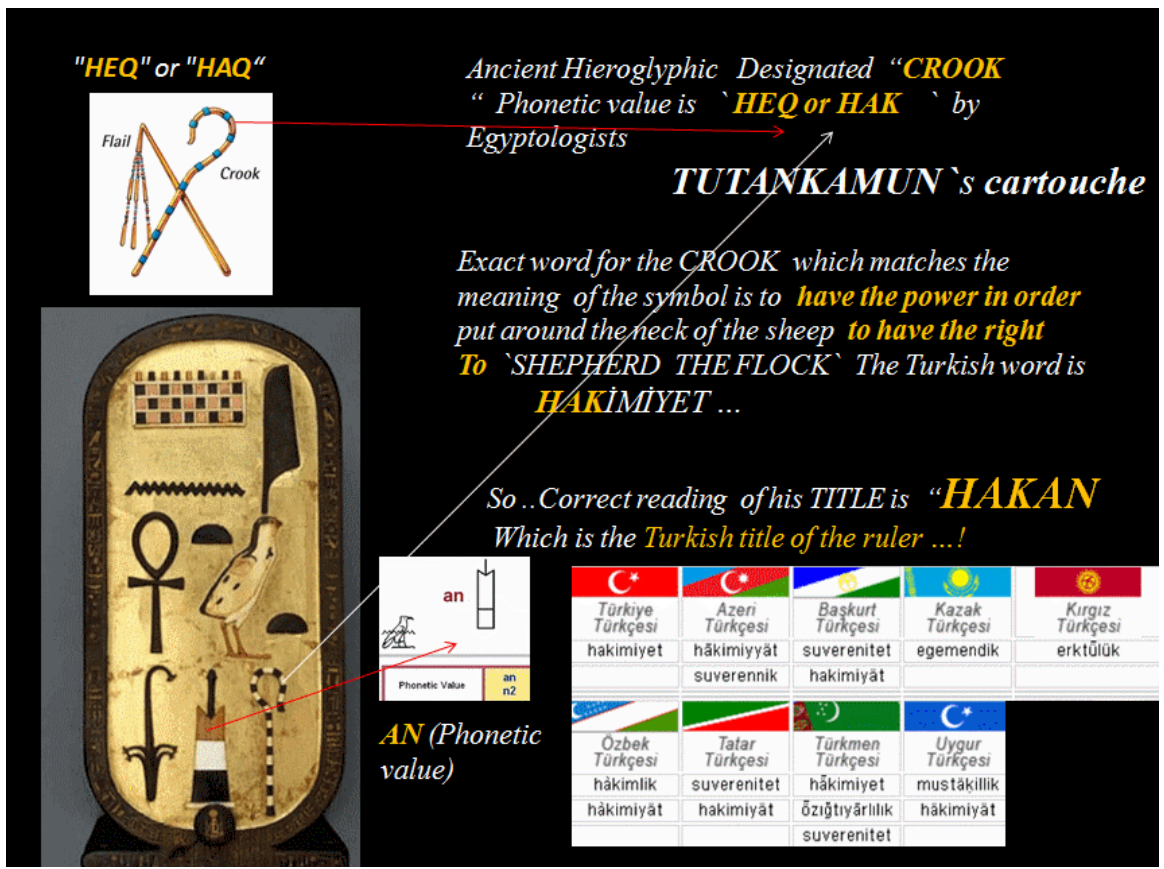

Picture 7. http://tureng.com/tr/turkce-ingilizce/hakimiyet Hakimiyet http://tureng.com/tr/turkce-ingilizce/hakan Hakan

Turkish Dialects official web page for TÜRK DİL KURUMU

http://www.tdk.gov.tr/index.php?option=com_lehceler\&arama=lehceler\&guid=TDK.LH C.59806e6fe90526.22133333.

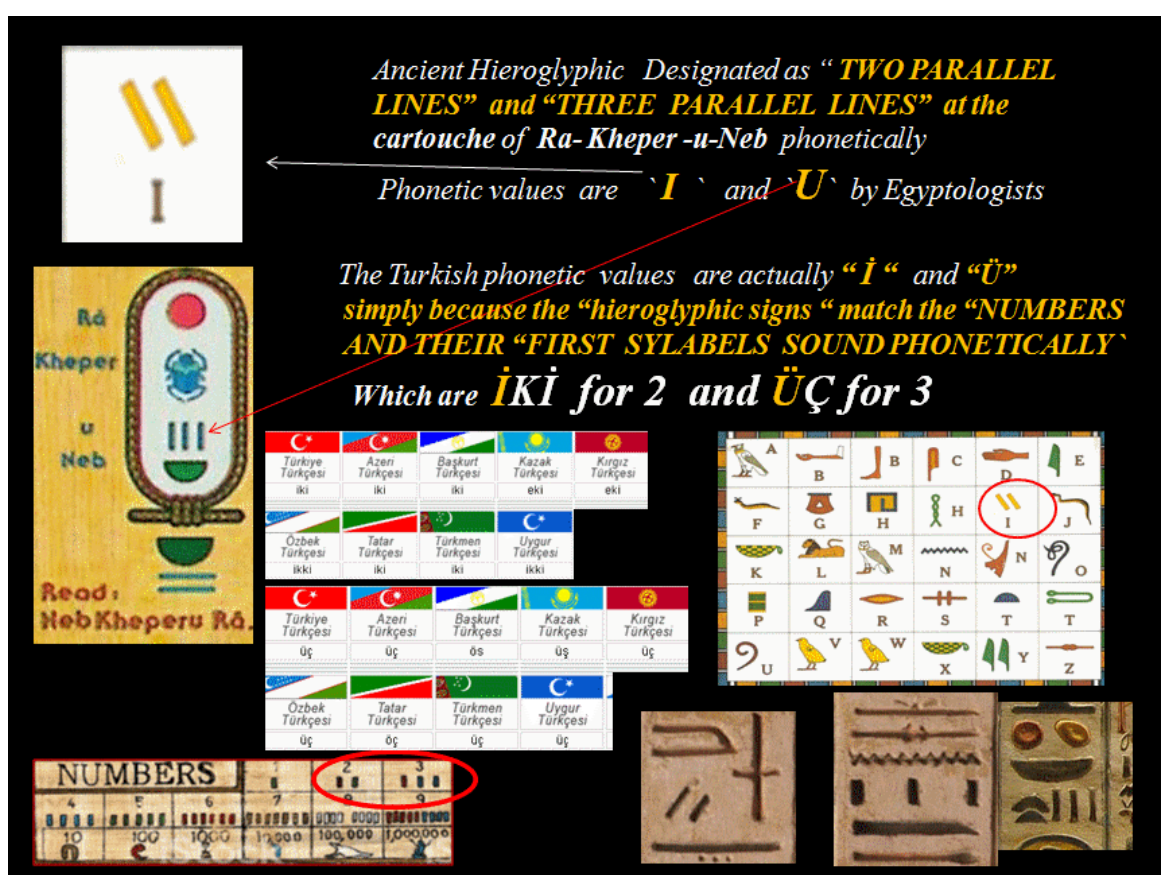

Picture 8. http://tureng.com/tr/turkce-ingilizce/iki İki http://tureng.com/tr/turkce-ingilizce/\%C3\%BC\%C3\%A7 Üç Turkish Dialects official web page for TÜRK DİL KURUMU http://www.tdk.gov.tr/index.php?option=com_lehceler\&arama=lehceler\&guid=TDK.LH C.59806e6fe90526.22133333. 


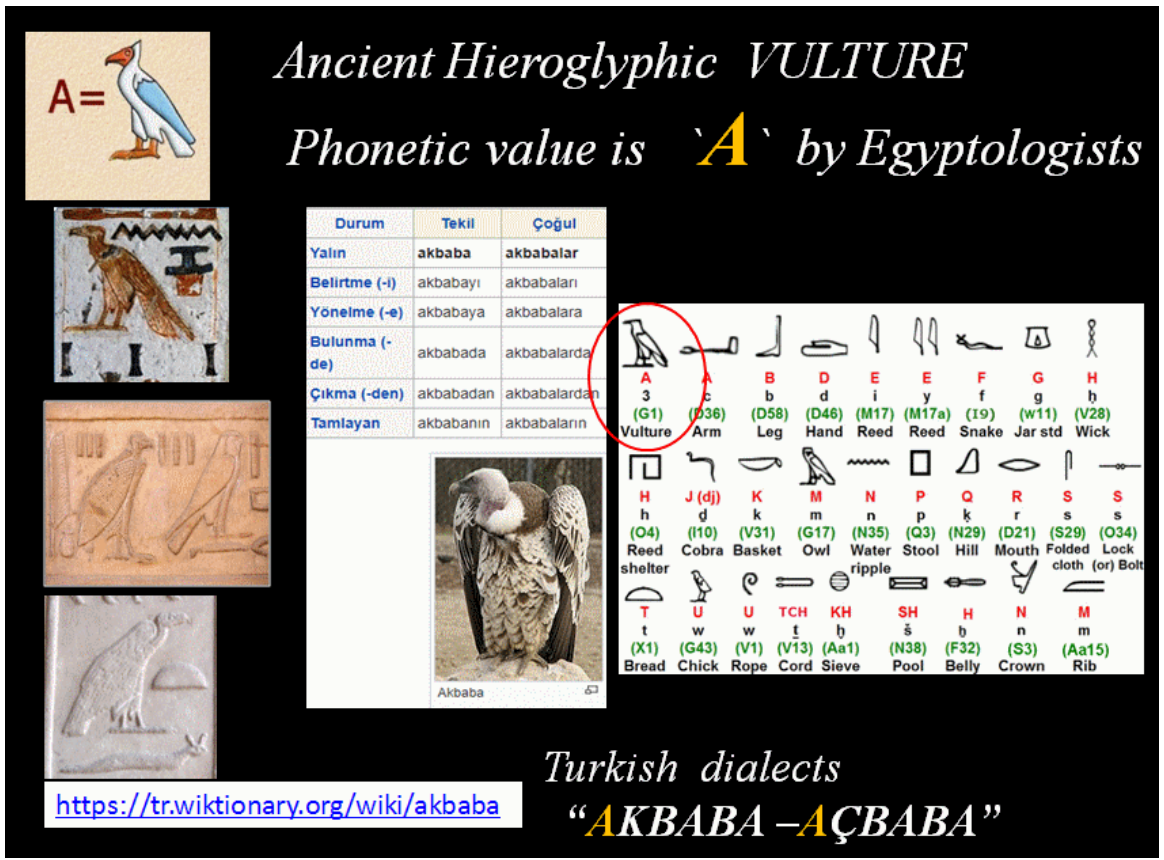

Picture 9. http://tureng.com/tr/turkce-ingilizce/akbaba Akbaba

Turkish Dialects official web page for TÜRK DİL KURUMU

http://www.tdk.gov.tr/index.php?option=com_lehceler\&arama=lehceler\&guid=TDK.LH C.59806e6fe90526.22133333.

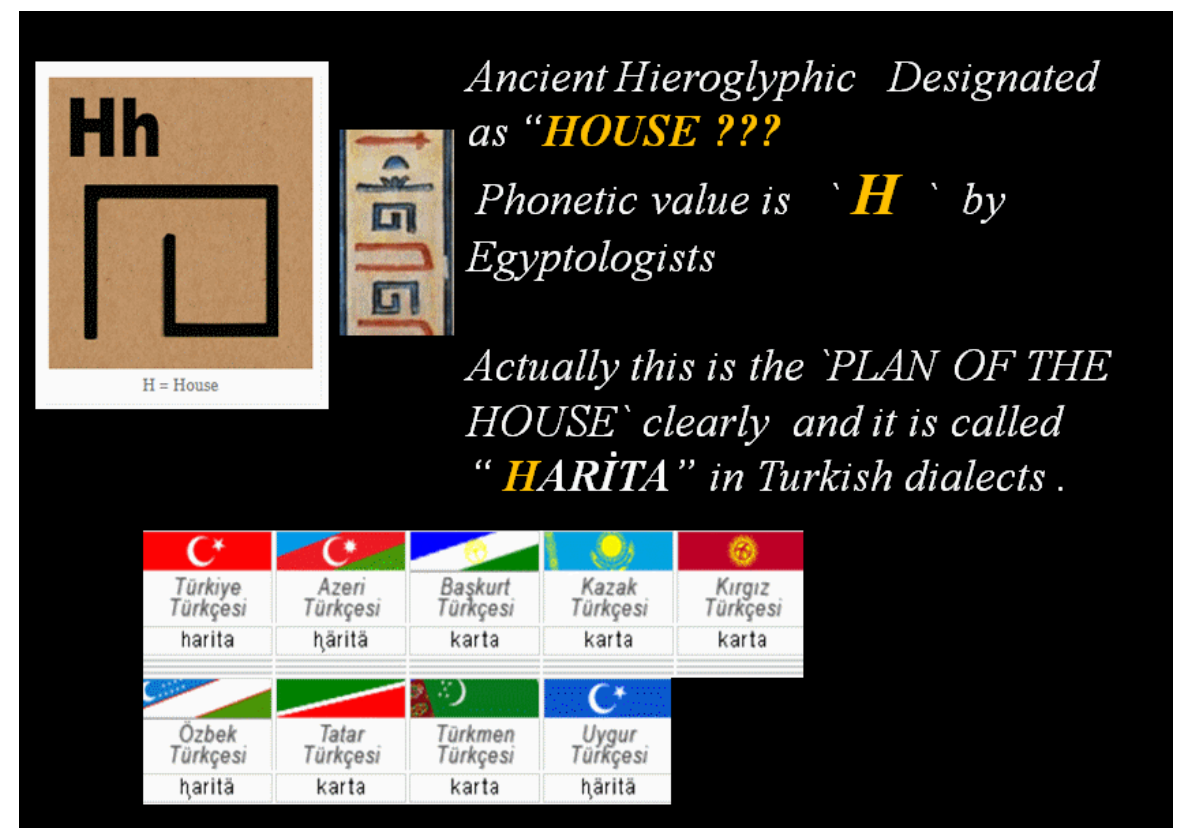

Picture 10. http://tureng.com/tr/turkce-ingilizce/harita Harita Turkish Dialects official web page for TÜRK DİL KURUMU

http://www.tdk.gov.tr/index.php?option=com_lehceler\&arama=lehceler\&guid=TDK.LH C.59806e6fe90526.22133333. 


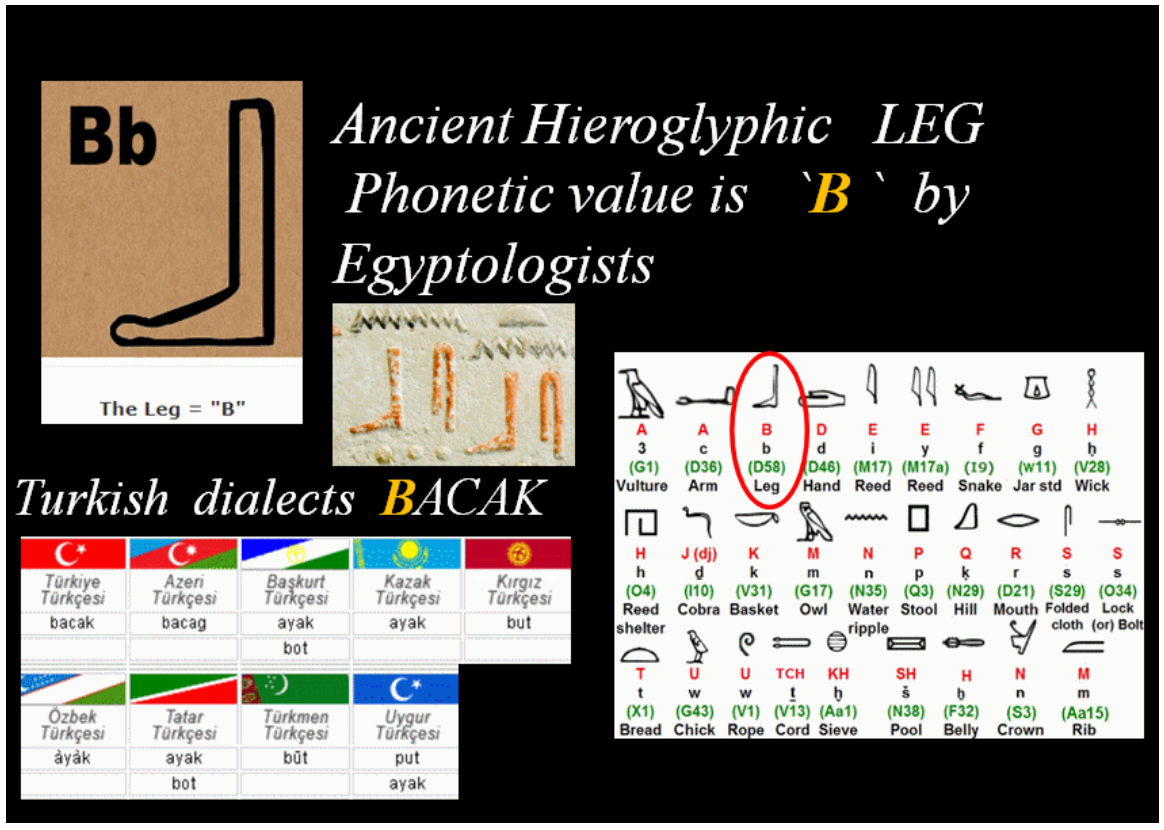

Picture 11. http://tureng.com/tr/turkce-ingilizce/bacak Bacak Turkish Dialects official web page for TÜRK DİL KURUMU http://www.tdk.gov.tr/index.php?option=com_lehceler\&arama=lehceler\&guid=TDK.LH C.59806e6fe90526.22133333.

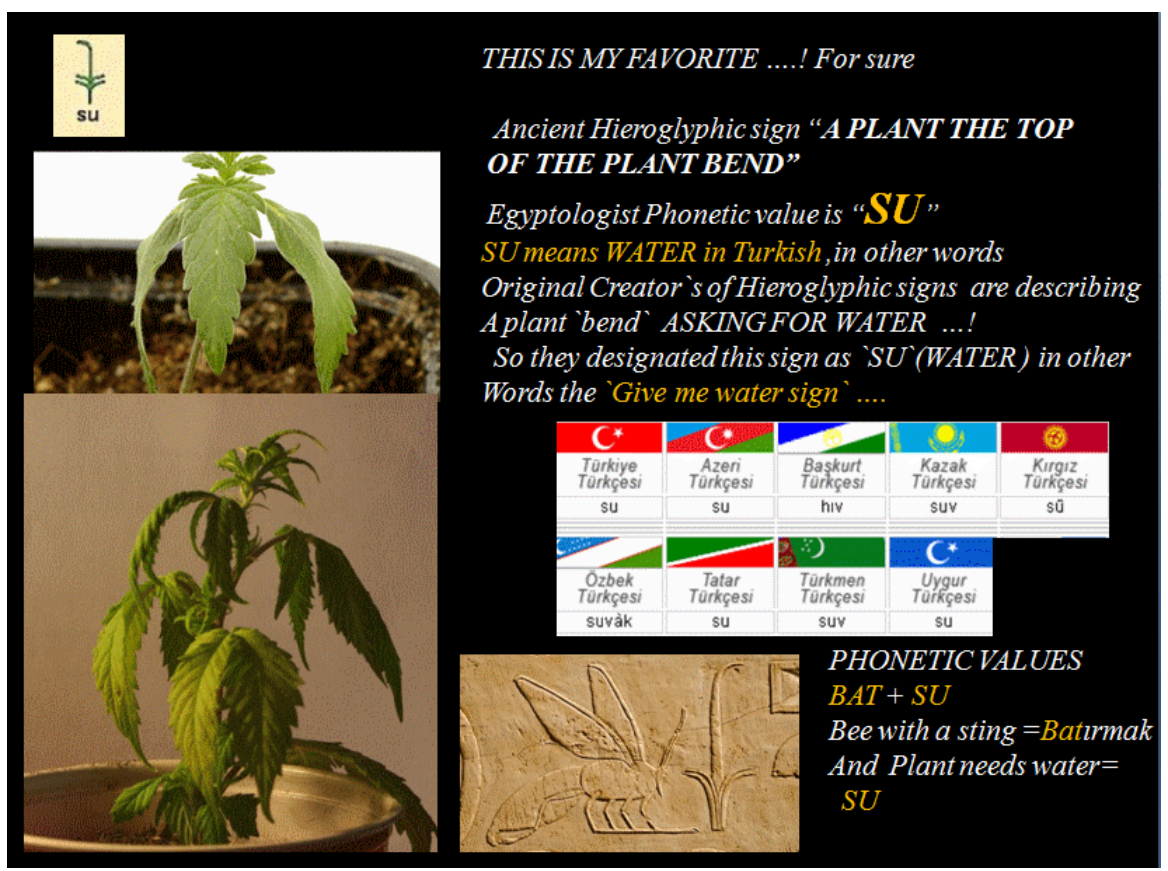

Picture 12. http://tureng.com/tr/turkce-ingilizce/su Su

Turkish Dialects official web page for TÜRK DİL KURUMU

http://www.tdk.gov.tr/index.php?option=com_lehceler\&arama=lehceler\&guid=TDK.LH C.59806e6fe90526.22133333

http://tureng.com/tr/turkce-ingilizce/bat\%C4\%B1rmak Batırmak http://www.achiq.org/pitikler/dlt---.pdf Divanı Lügati-t Türk (Batırmak). 


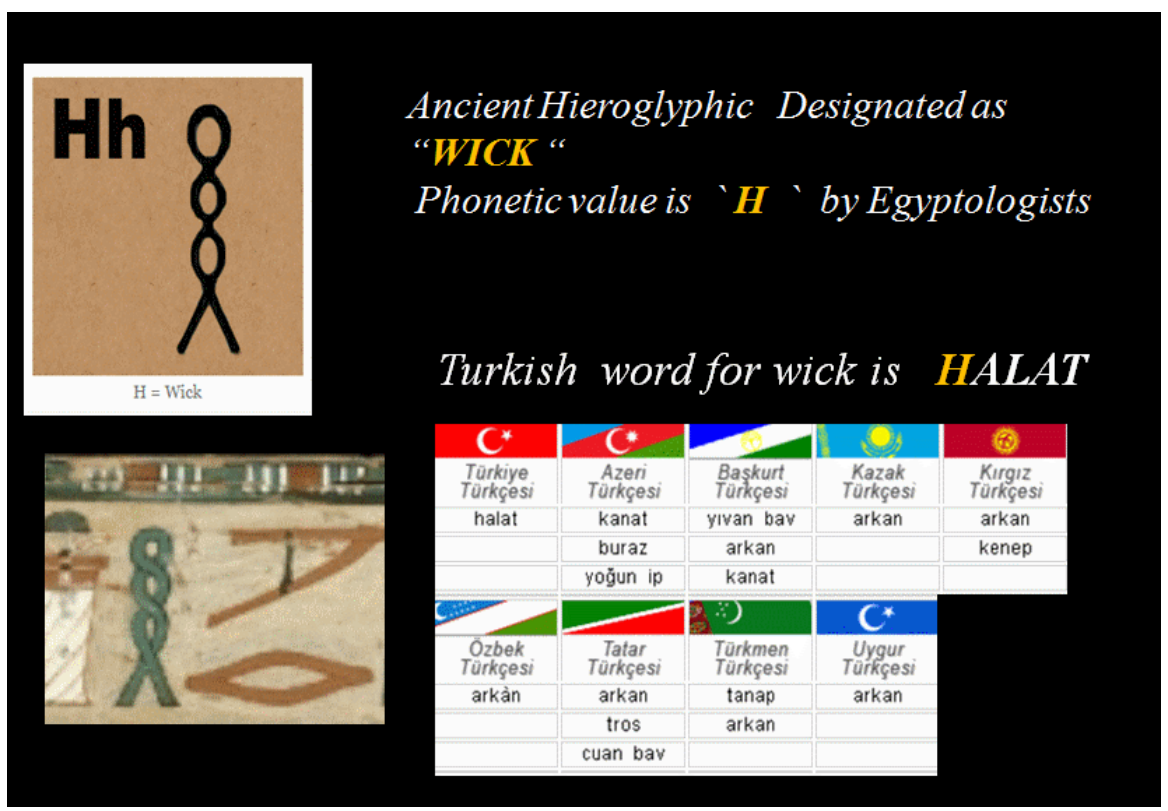

Picture 13. http://tureng.com/tr/turkce-ingilizce/halat Halat Turkish Dialects official web page for TÜRK DİL KURUMU http://www.tdk.gov.tr/index.php?option=com_lehceler\&arama=lehceler\&guid=TDK.LH C.59806e6fe90526.22133333.

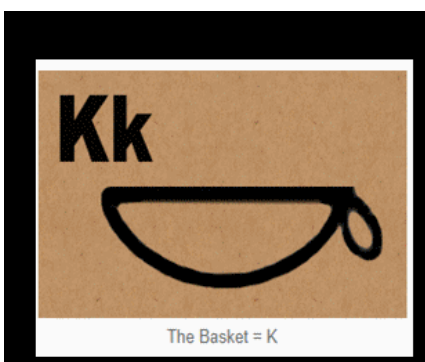

Ancient Hieroglyphic

Designated as "Basket"

Phonetic value is ' $K$ by Egyptologists

Turkish dialect name for the picture is 'KAP

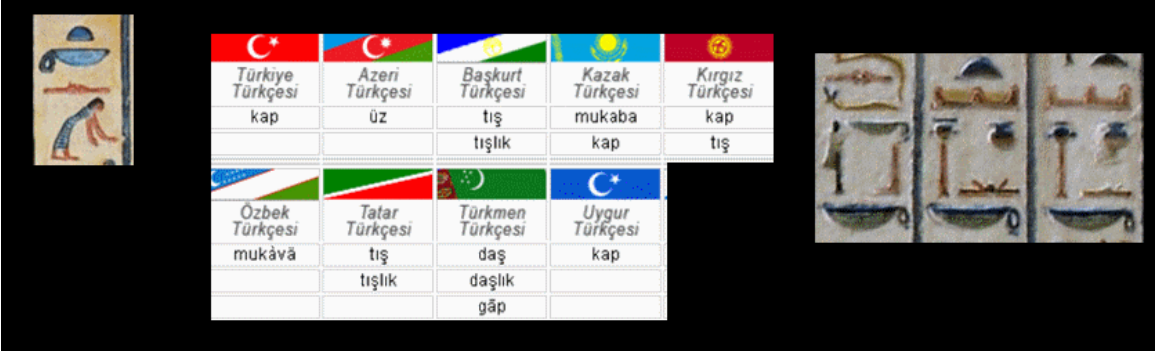

Picture 14. http://tureng.com/tr/turkce-ingilizce/kap Kap Turkish Dialects official web page for TÜRK DİL KURUMU

http://www.tdk.gov.tr/index.php?option=com_lehceler\&arama=lehceler\&guid=TDK.LH C.59806e6fe90526.22133333. 


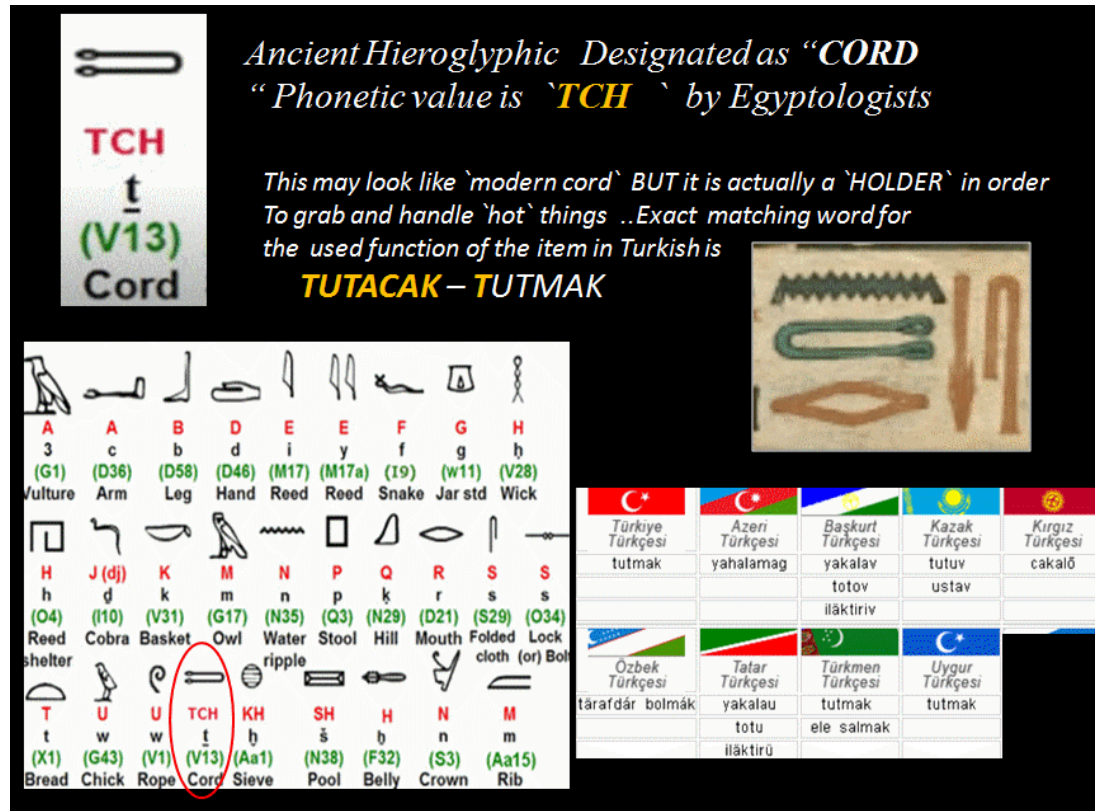

Picture 15. http://tureng.com/tr/turkce-ingilizce/tutmak Tutmak http://tureng.com/tr/turkce-ingilizce/tutacak Tutacak Turkish Dialects official web page for TÜRK DİL KURUMU http://www.tdk.gov.tr/index.php?option=com_lehceler\&arama=lehceler\&guid=TDK.LH C.59806e6fe90526.22133333.

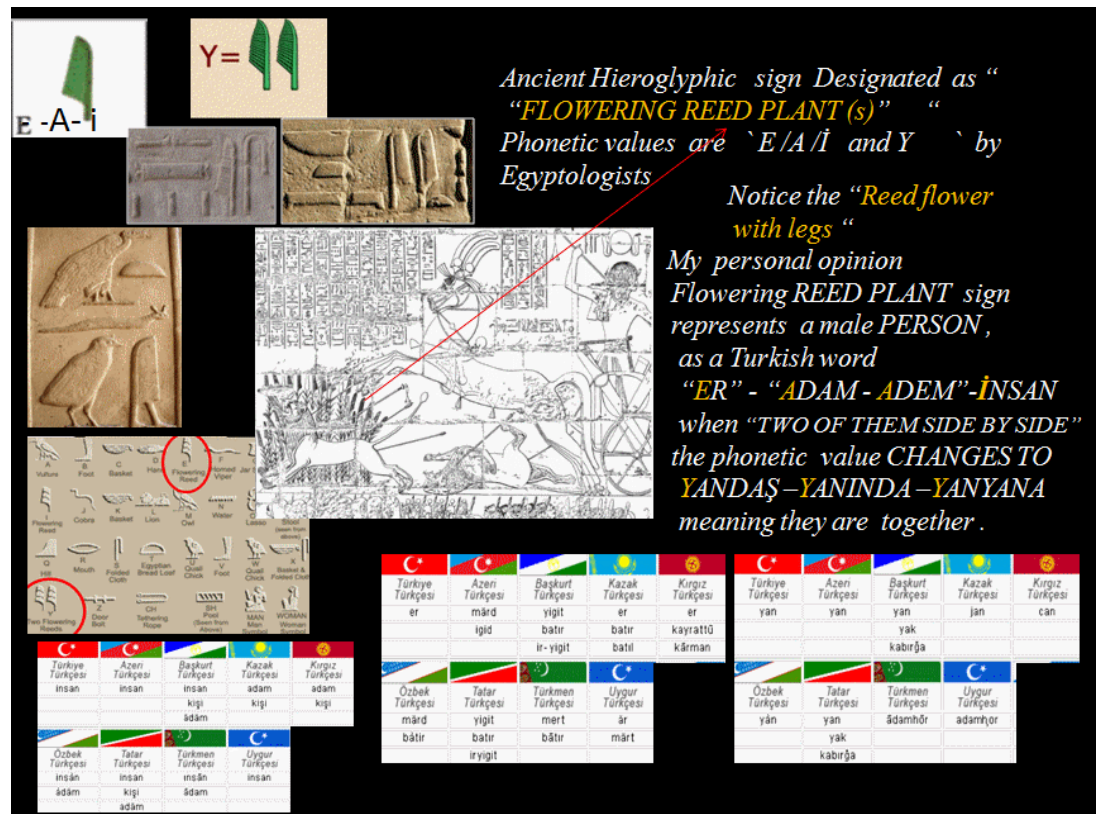

Picture 16. http://tureng.com/tr/turkce-ingilizce/adam Adam http://tureng.com/tr/turkce-ingilizce/insan İnsan http://tureng.com/tr/turkce-ingilizce/er\%20ki\%C5\%9Fi Er kişi http://tureng.com/tr/turkce-ingilizce/yan\%C4\%B1\%20ba\%C5\%9F\%C4\%B1nda Yanı başında Turkish Dialects official web page for TÜRK DİL KURUMU http://www.tdk.gov.tr/index.php?option=com_lehceler\&arama=lehceler\&guid=TDK.LH C.59806e6fe90526.22133333. 


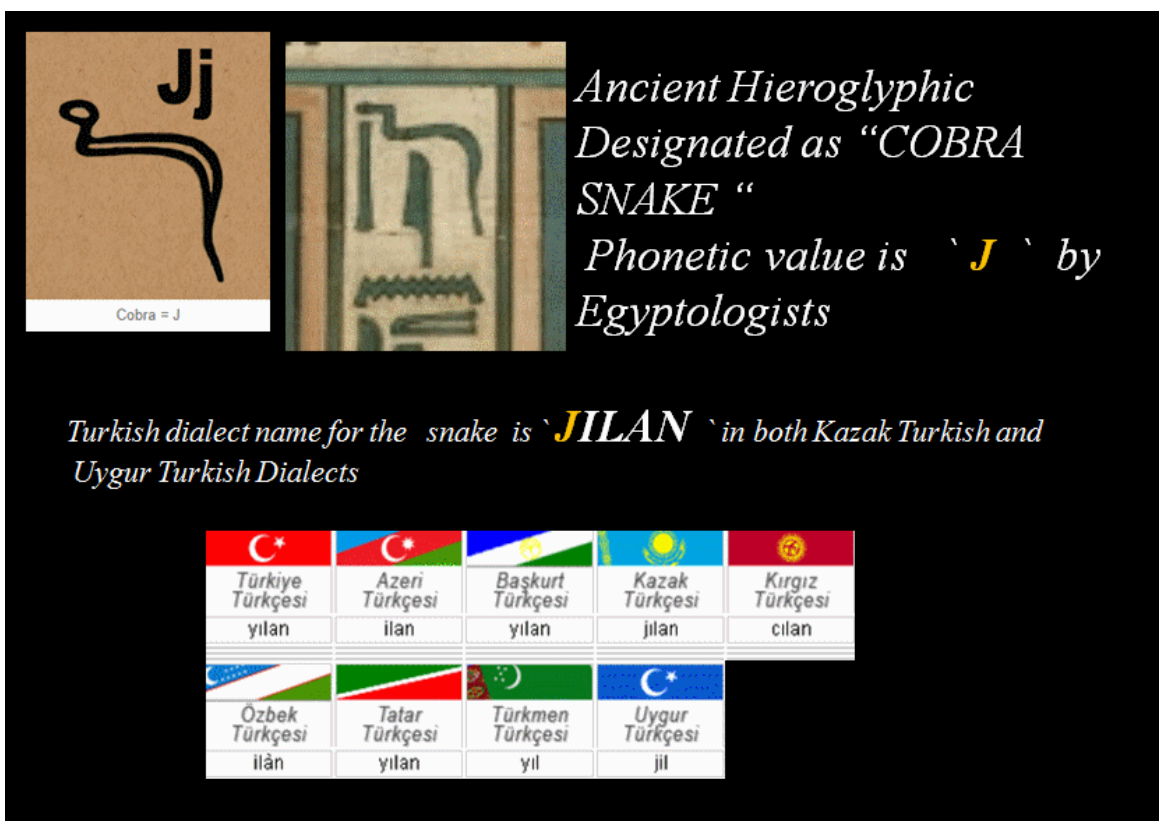

Picture 17. http://tureng.com/tr/turkce-ingilizce/y\%C4\%B1lan Yllan Turkish Dialects official web page for TÜRK DİL KURUMU

http://www.tdk.gov.tr/index.php?option=com_lehceler\&arama=lehceler\&guid=TDK.LH C.59806e6fe90526.22133333.

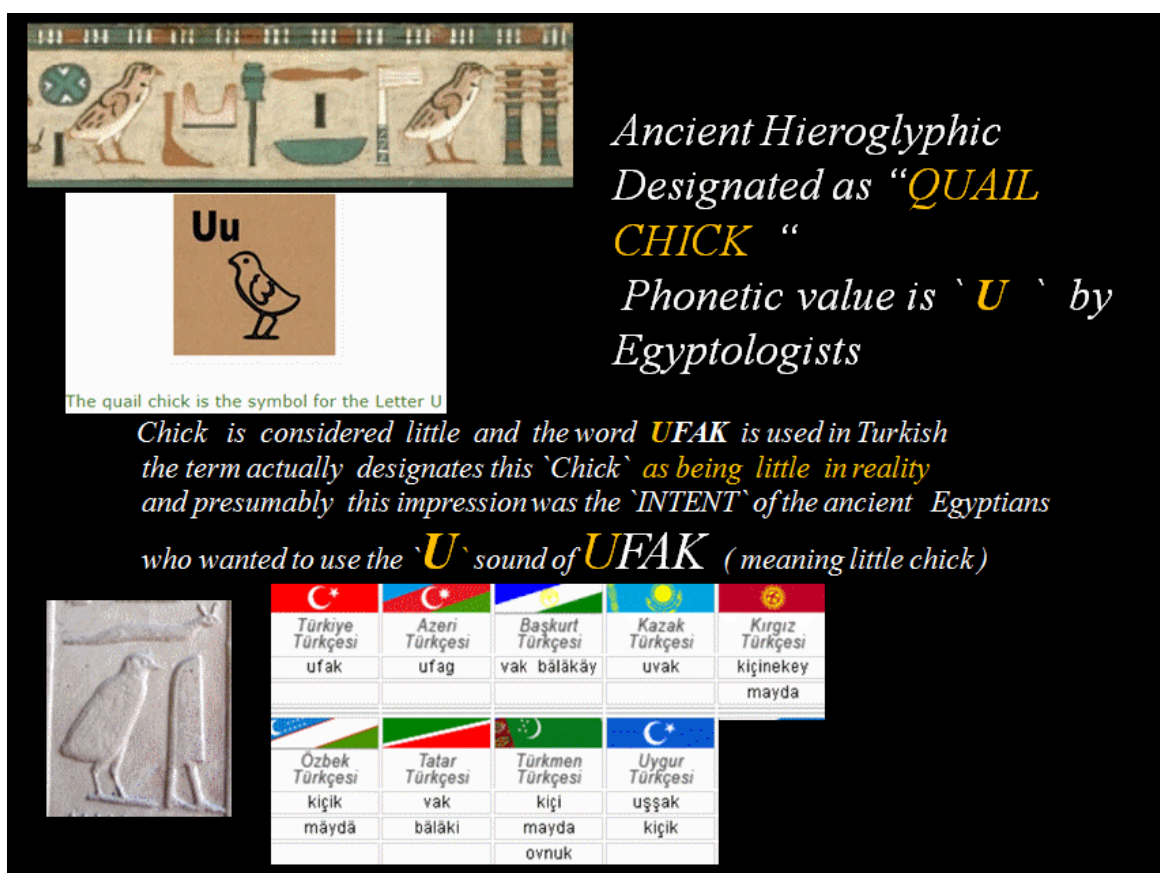

Picture 18. http://tureng.com/tr/turkce-ingilizce/ufak Ufak Turkish Dialects official web page for TÜRK DİL KURUMU http://www.tdk.gov.tr/index.php?option=com_lehceler\&arama=lehceler\&guid=TDK.LH C.59806e6fe90526.22133333. 


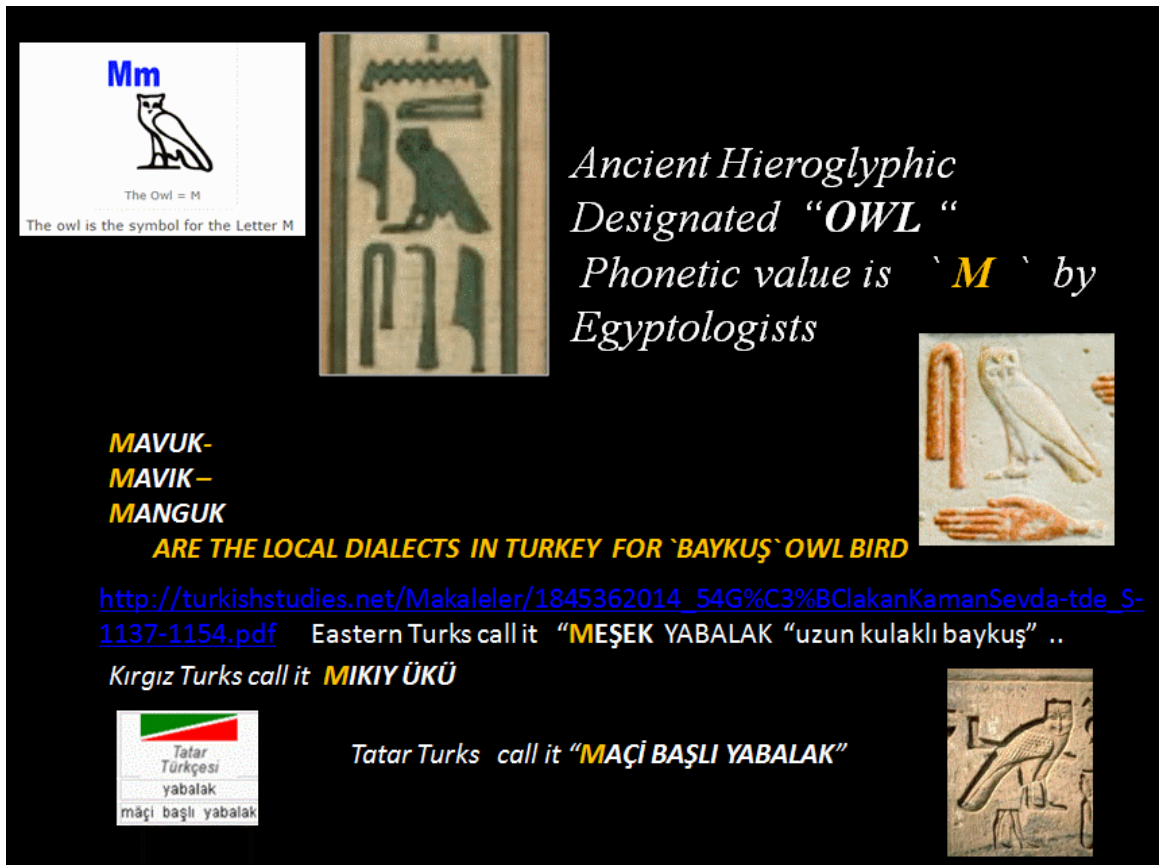

Picture 19.

http://turkishstudies.net/Makaleler/1845362014_54G\%C3\%BClakanKamanSevda-tde_S-1 137-1154.pdf

BAYKUŞ KELIMMESİ VE BAYKUŞLA İLGİLİ İNANÇLAR ÜZERİNE

http://www.tdk.gov.tr/index.php?option=com_lehceler\&arama=lehceler\&guid=TDK.LH C.59806e6fe90526.22133333 Turkish Dialects official web page for TÜRK DİL KURUMU http://www.kazimcapaci.com/FR_baykus.htm Gece yırtıcılar1-Baykuş.

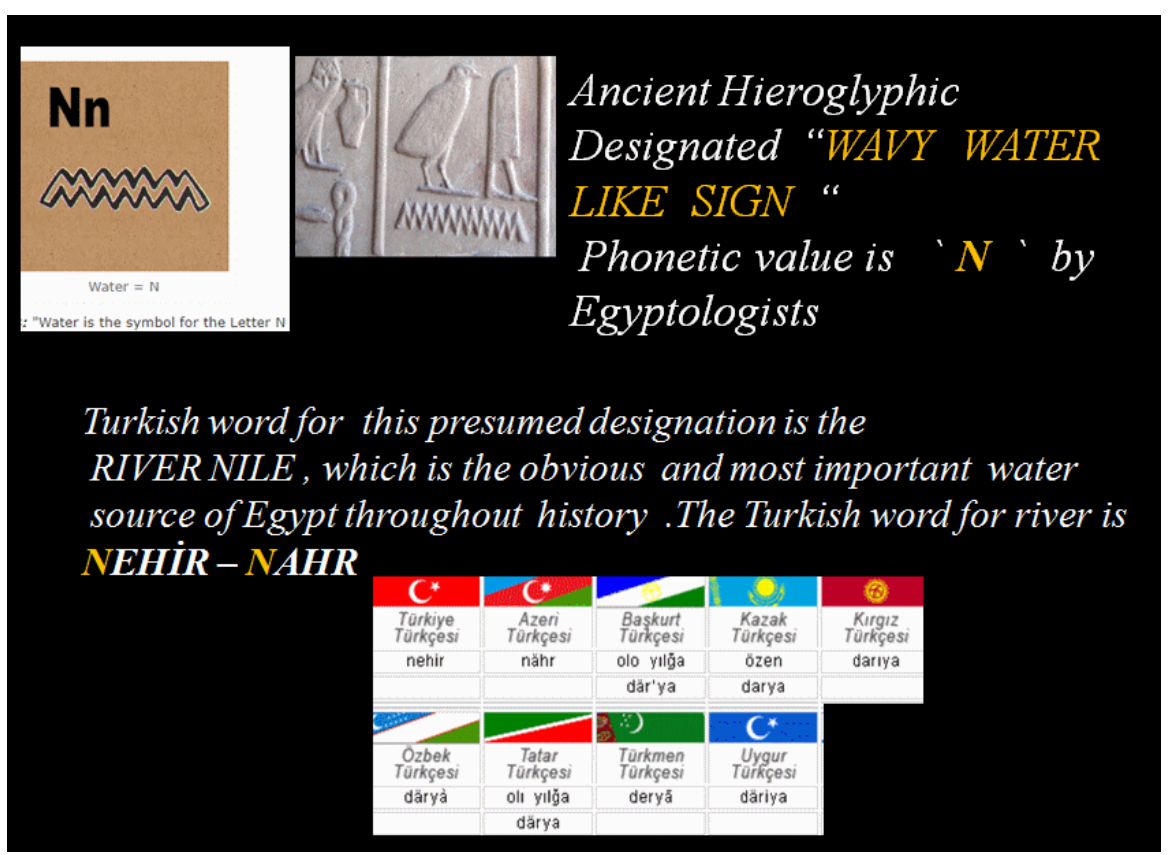

Picture 20. http://tureng.com/tr/turkce-ingilizce/nehir Nehir Turkish Dialects official web page for TÜRK DİL KURUMU

http://www.tdk.gov.tr/index.php?option=com_lehceler\&arama=lehceler\&guid=TDK.LH C.59806e6fe90526.22133333. 


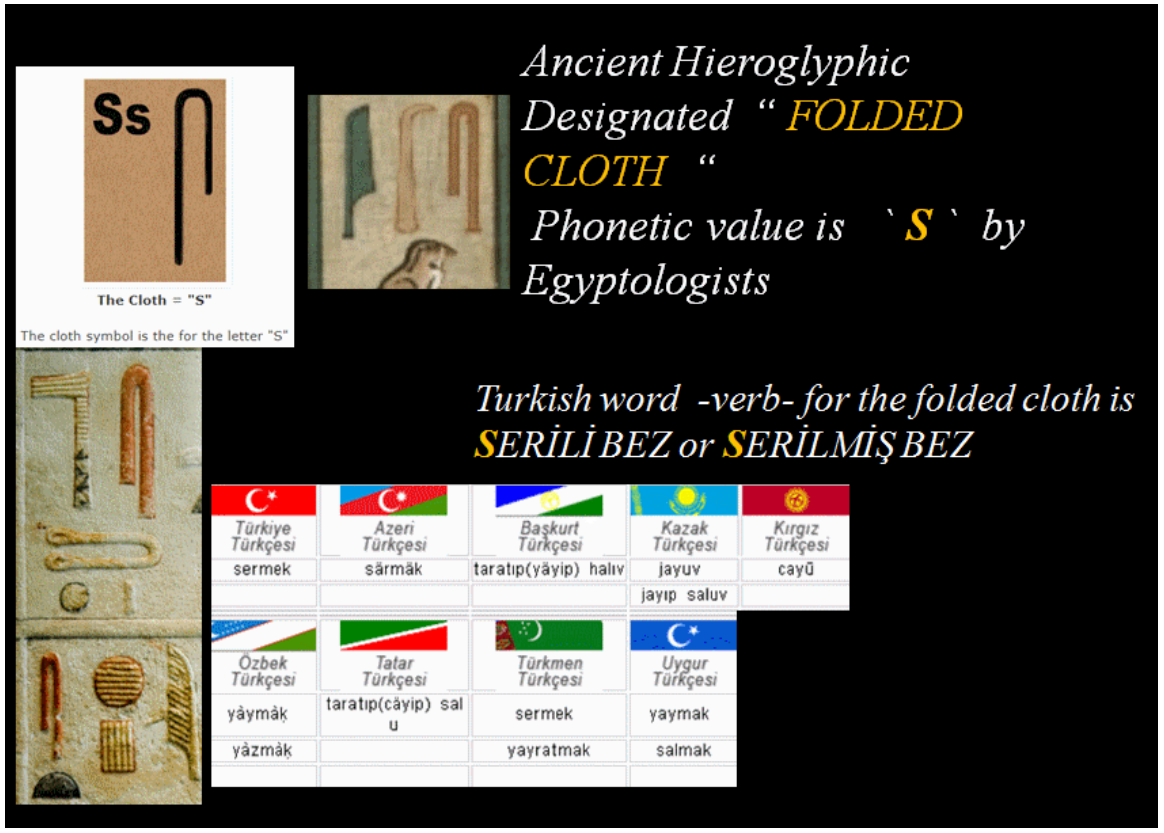

Picture 21. http://tureng.com/tr/turkce-ingilizce/sermek Sermek Turkish Dialects official web page for TÜRK DİL KURUMU

http://www.tdk.gov.tr/index.php?option=com_lehceler\&arama=lehceler\&guid=TDK.LH C.59806e6fe90526.22133333.

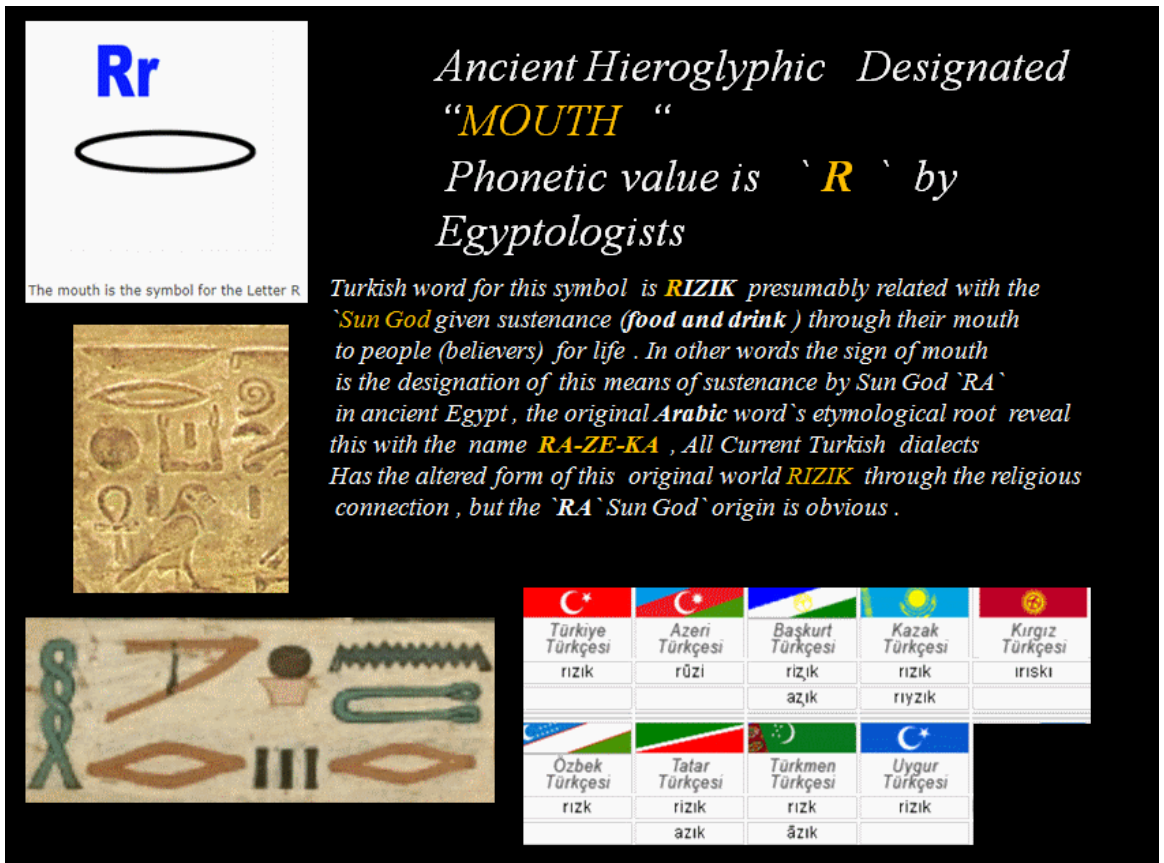

Picture 22. http://tureng.com/tr/turkce-ingilizce/r\%C4\%B1z\%C4\%B1k Rizık Turkish Dialects official web page for TÜRK DİL KURUMU

http://www.tdk.gov.tr/index.php?option=com_lehceler\&arama=lehceler\&guid=TDK.LH C.59806e6fe90526.22133333. 


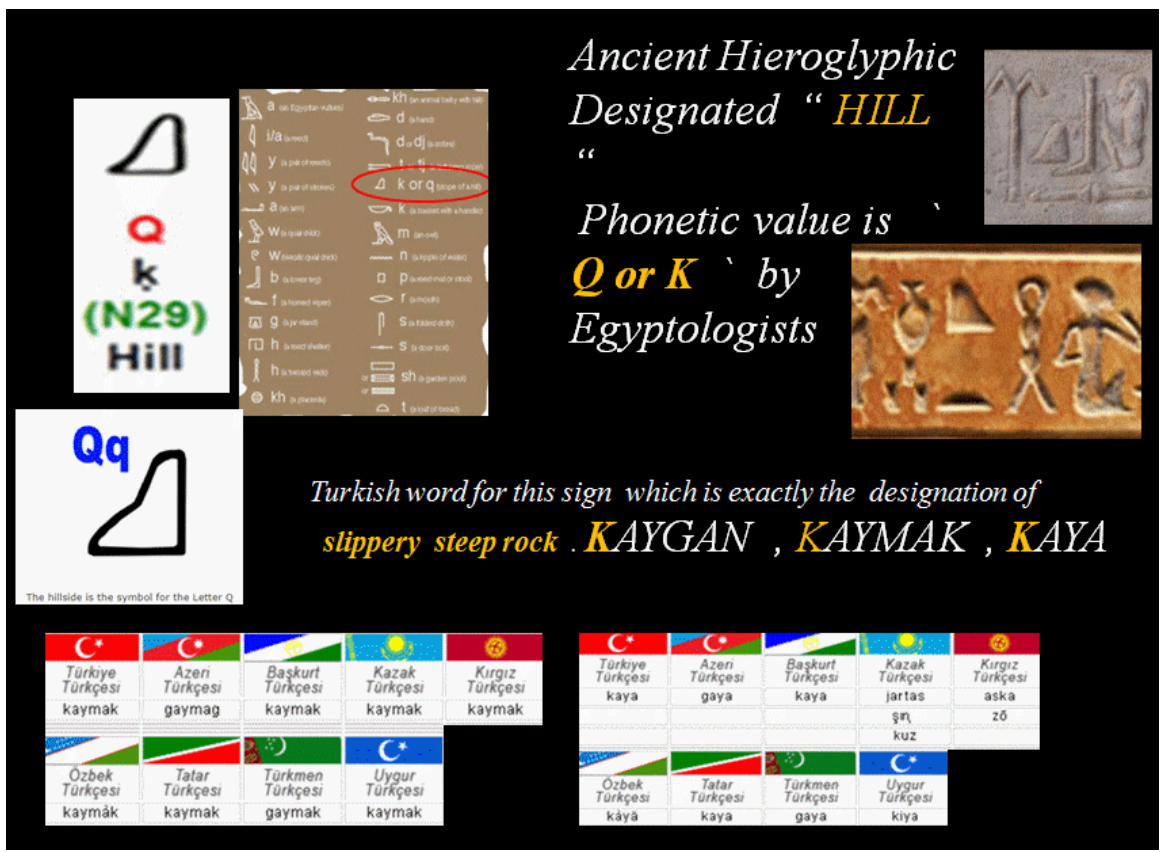

Picture 23. http://tureng.com/tr/turkce-ingilizce/kaya Kaya http://tureng.com/tr/turkce-ingilizce/kaygan Kaygan http://tureng.com/tr/turkce-ingilizce/kaymak Kaymak Turkish Dialects official web page for TÜRK DİL KURUMU http://www.tdk.gov.tr/index.php?option=com_lehceler\&arama=lehceler\&guid=TDK.LH C.59806e6fe90526.22133333.

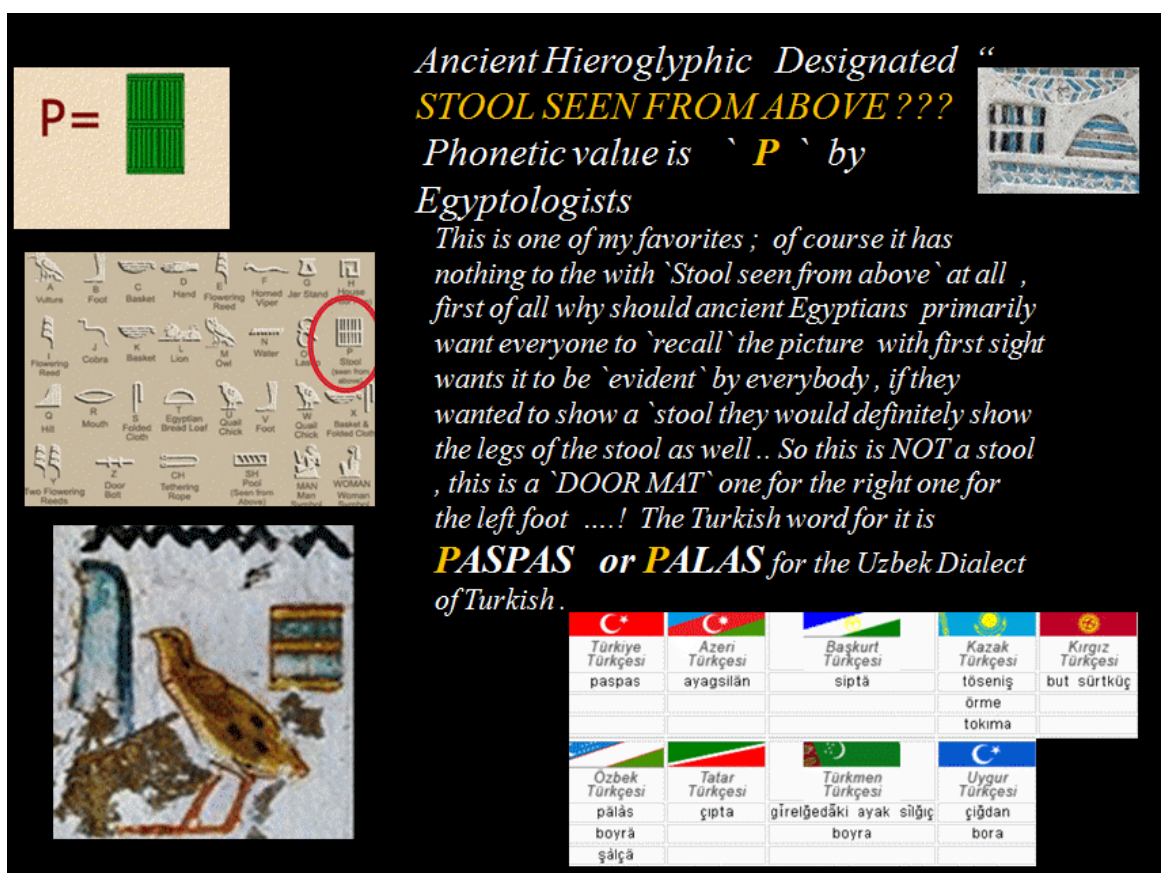

Picture 24. http://tureng.com/tr/turkce-ingilizce/paspas Paspas Turkish Dialects official web page for TÜRK DİL KURUMU http://www.tdk.gov.tr/index.php?option=com_lehceler\&arama=lehceler\&guid=TDK.LH C.59806e6fe90526.22133333. 


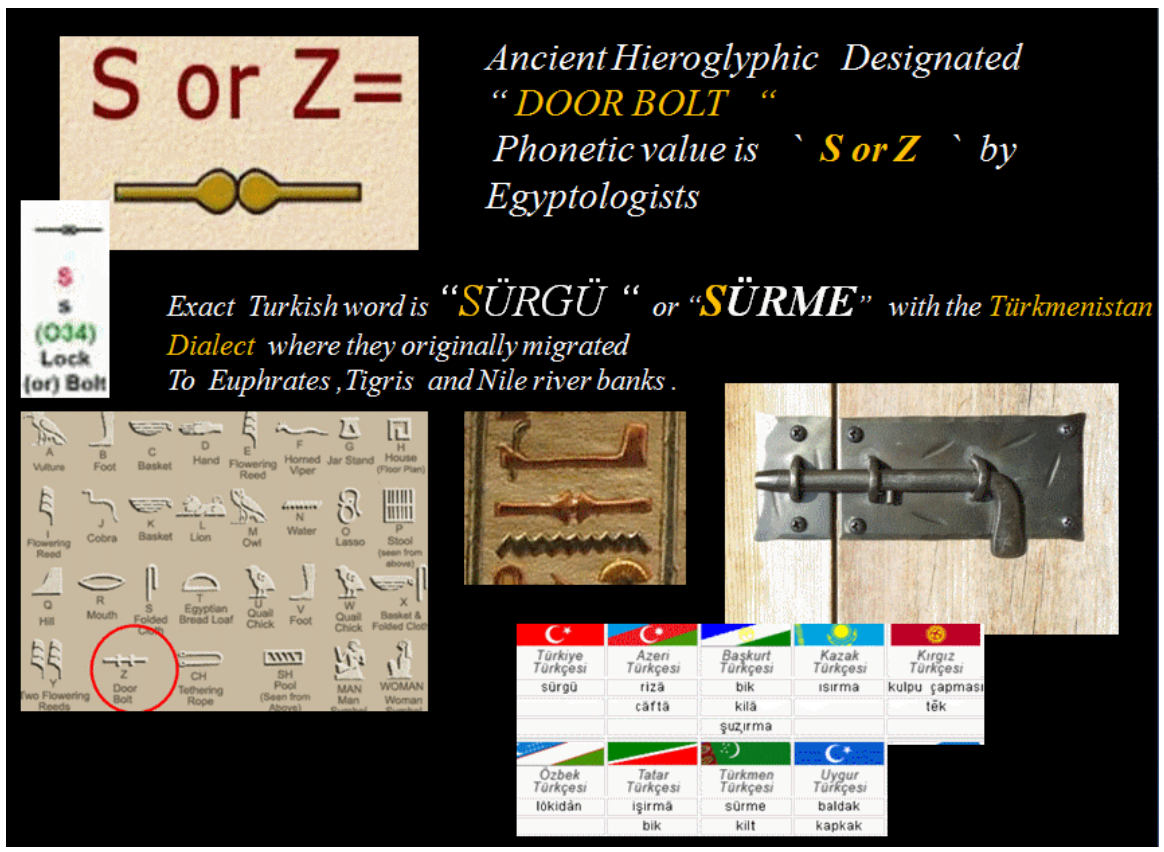

Picture 25. http://tureng.com/tr/turkce-ingilizce/s\%C3\%BCrg\%C3\%BC Sürgü http://www.tdk.gov.tr/index.php?option=com_lehceler\&arama=lehceler\&guid=TDK.LH C.59806e6fe90526.22133333

Turkish Dialects official web page for TÜRK DİL KURUMU.

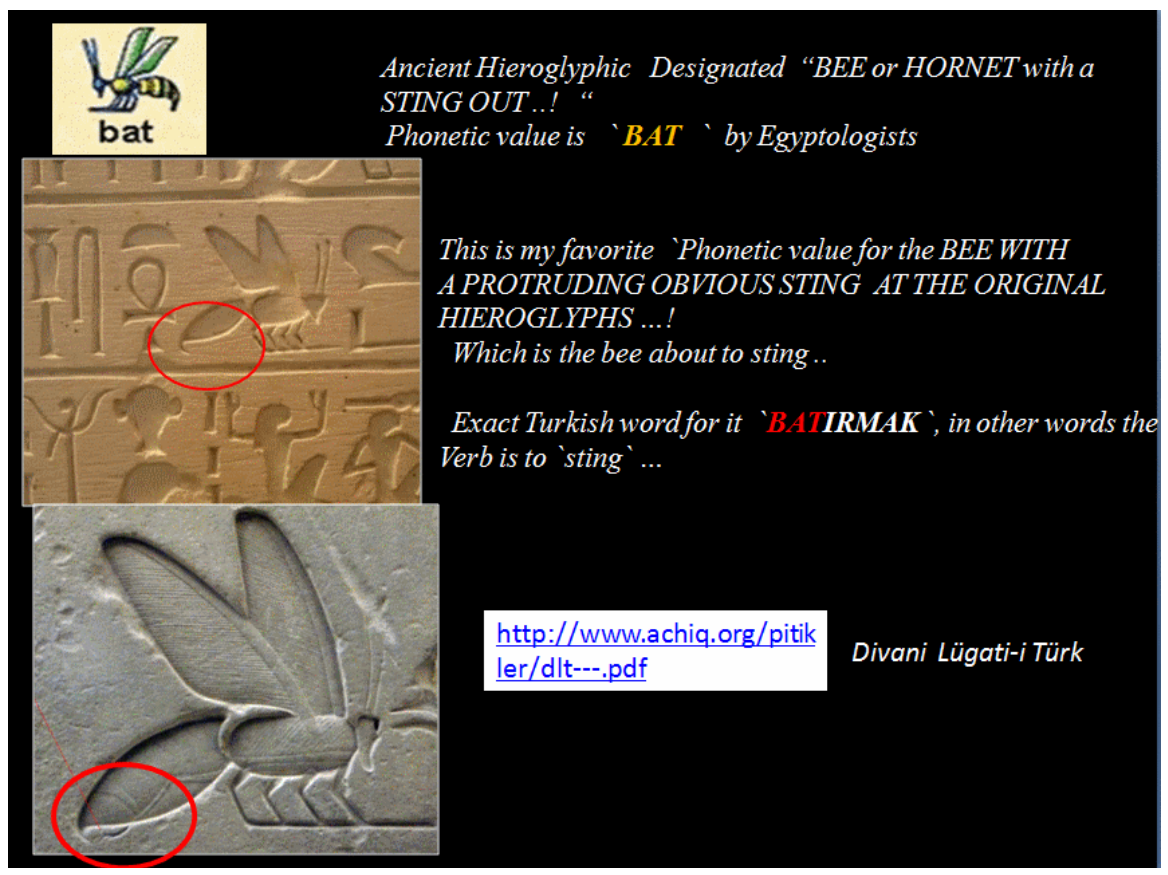

Picture 26. http://tureng.com/tr/turkce-ingilizce/bat\%C4\%B1rmak Batırmak http://www.achiq.org/pitikler/dlt---.pdf Divanı Lügati-t Türk (Batırmak). 


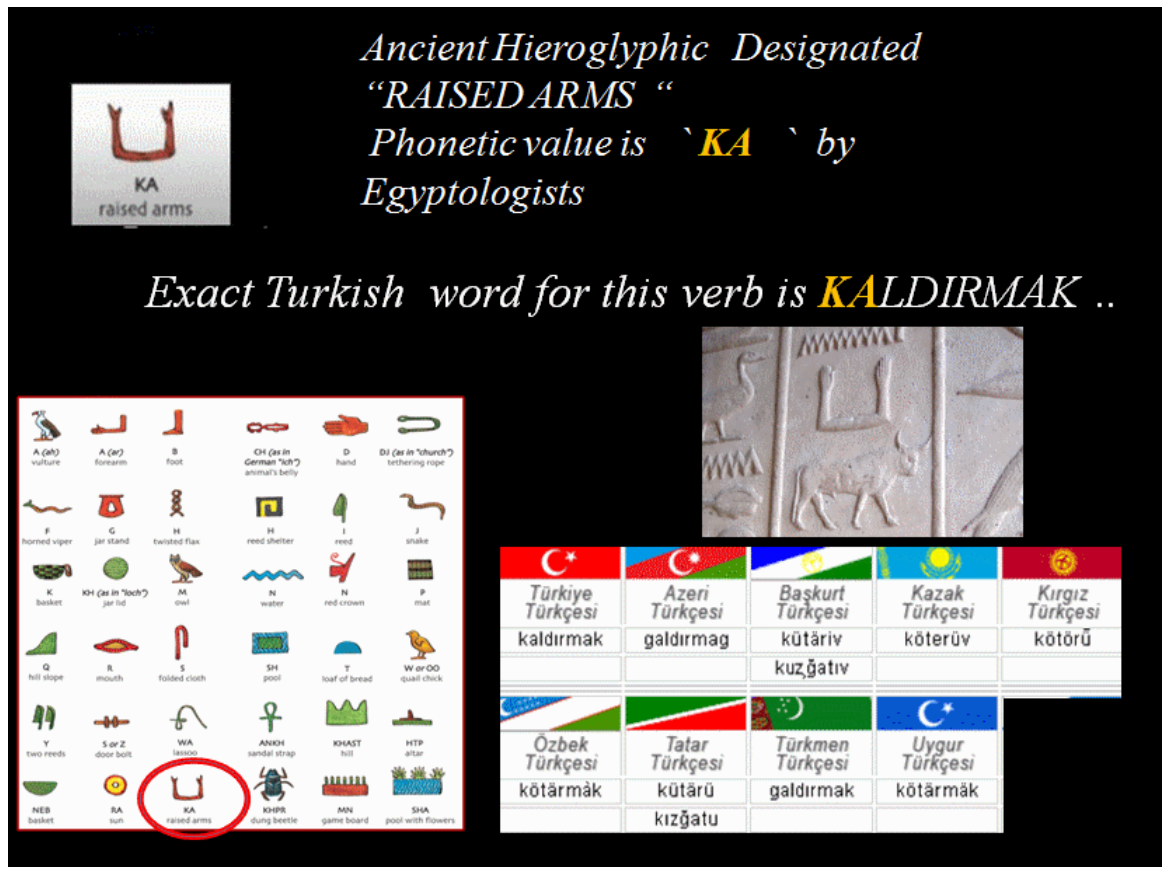

Picture 27. http://tureng.com/tr/turkce-ingilizce/kald\%C4\%B1rmak Kaldırmak Turkish Dialects official web page for TÜRK DİL KURUMU

http://www.tdk.gov.tr/index.php?option=com_lehceler\&arama=lehceler\&guid=TDK.LH C.59806e6fe90526.22133333.

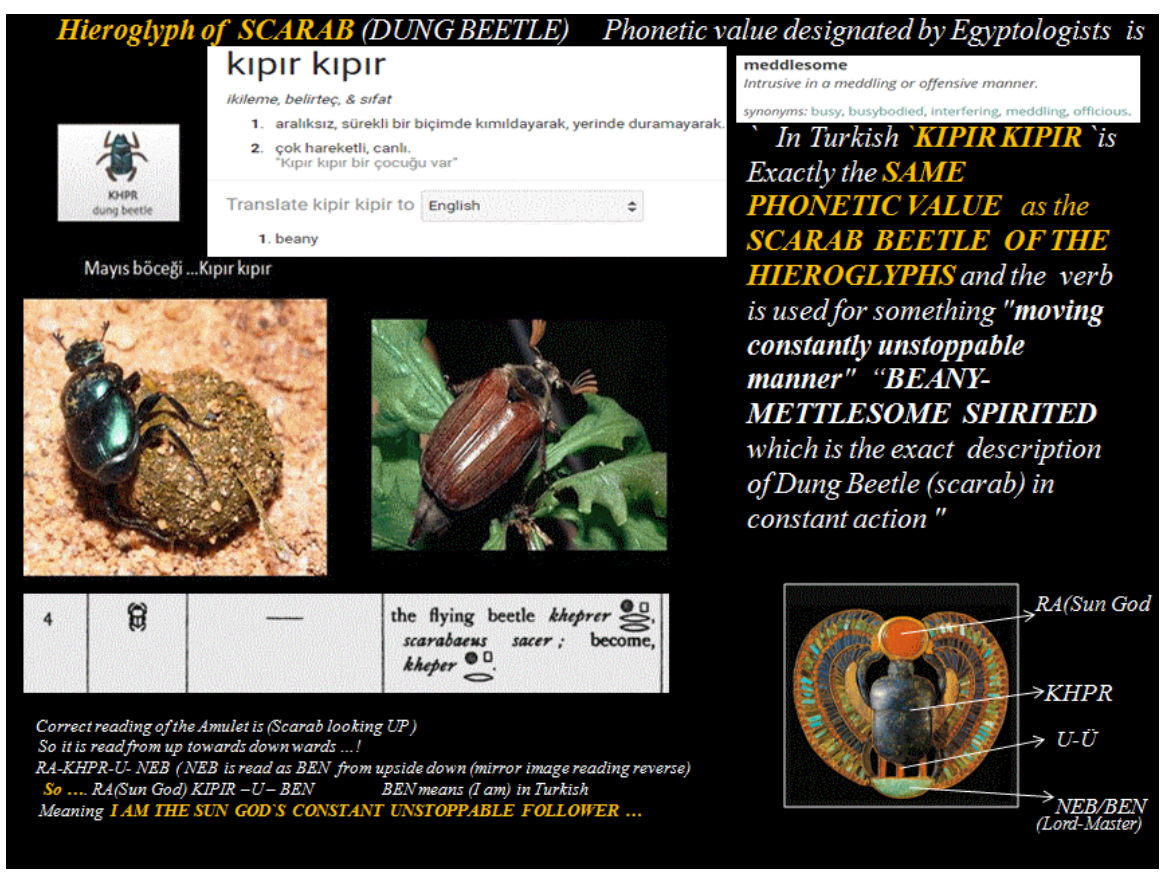

Picture 28.

http://tureng.com/tr/turkce-ingilizce/k\%C4\%B1p\%C4\%B1r\%20k\%C4\%B1p\%C4\%B1r Kipir Kipir

http://www.tdk.gov.tr/index.php?option=com_lehceler\&arama=lehceler\&guid=TDK.LH C.59806e6fe90526.22133333

Turkish Dialects official web page for TÜRK DİL KURUMU. 


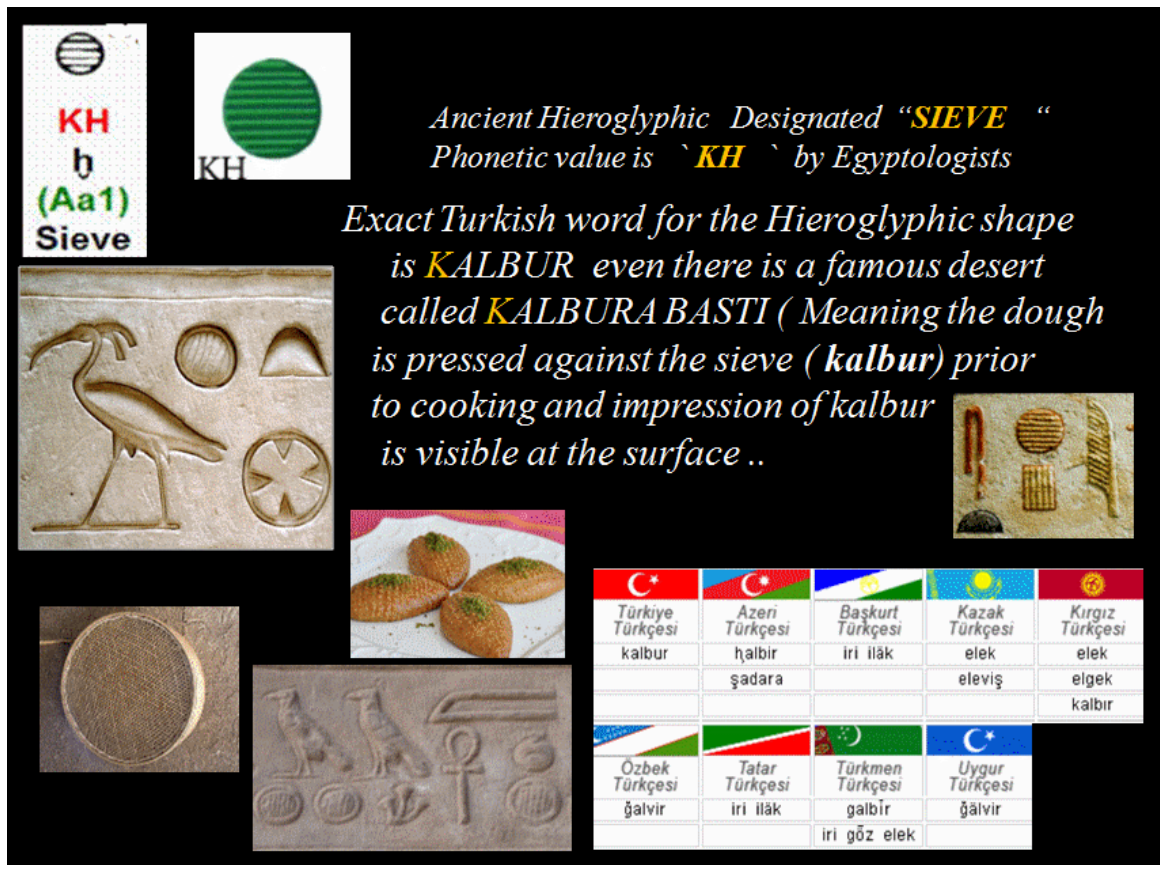

Picture 29. http://tureng.com/tr/turkce-ingilizce/kalbur Kalbur Turkish Dialects official web page for TÜRK DİL KURUMU http://www.tdk.gov.tr/index.php?option=com_lehceler\&arama=lehceler\&guid=TDK.LH C.59806e6fe90526.22133333.

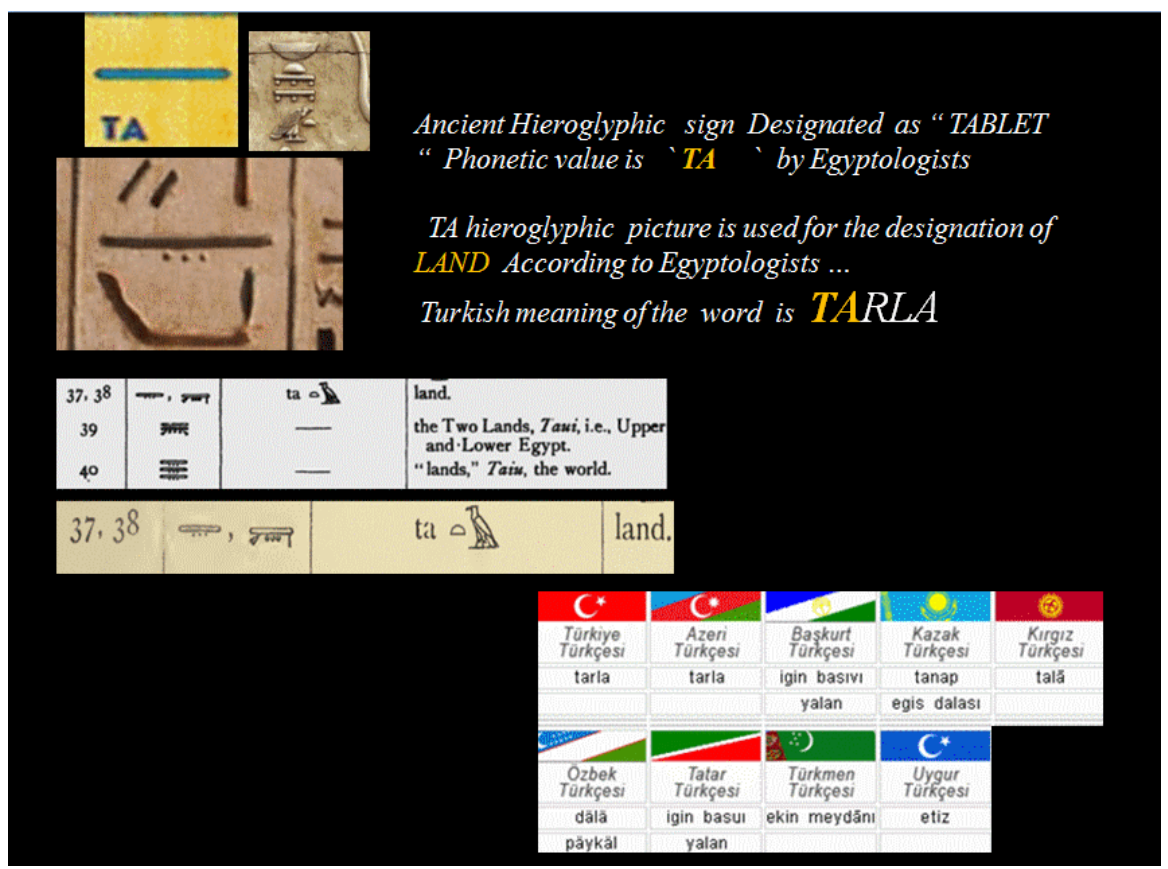

Picture 30. http://tureng.com/tr/turkce-ingilizce/tarla Tarla

http://www.tdk.gov.tr/index.php?option=com_lehceler\&arama=lehceler\&guid=TDK.LH C.59806e6fe90526.22133333

Turkish Dialects official web page for TÜRK DİL KURUMU. 


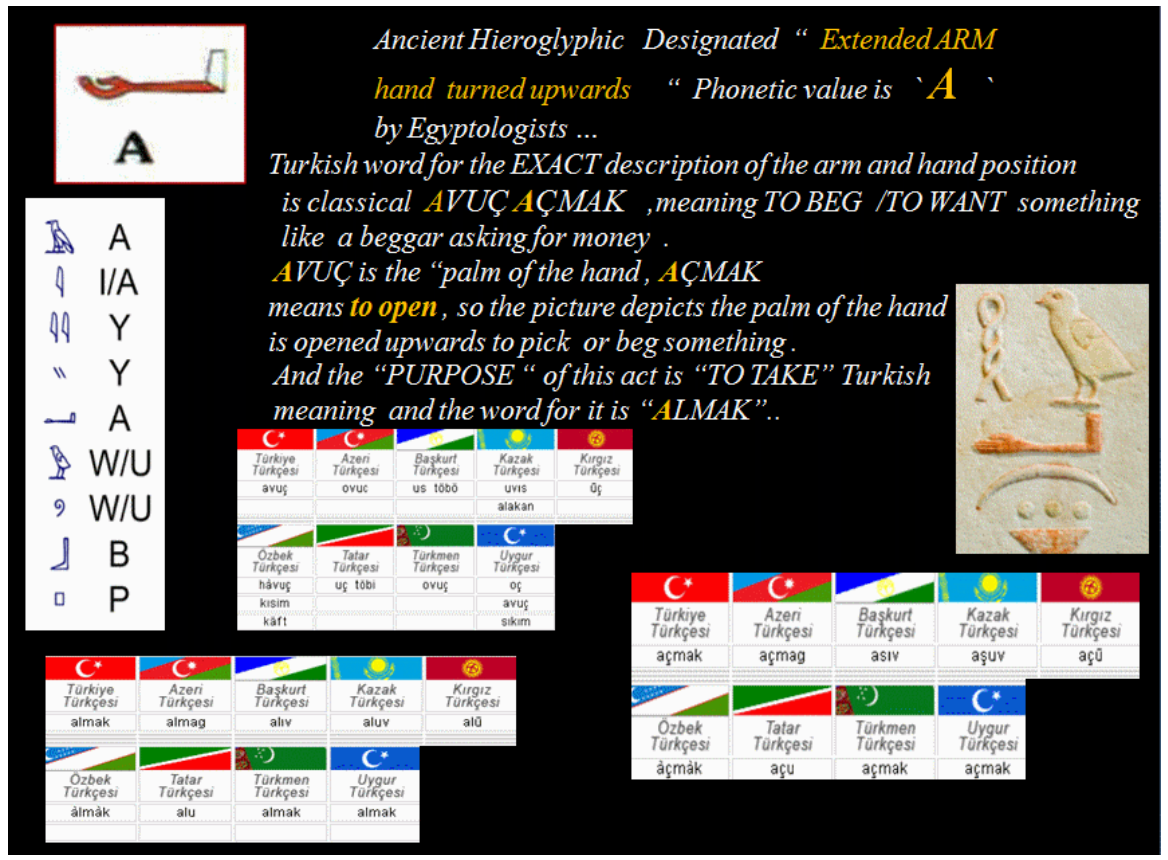

Picture 31. http://tureng.com/tr/turkce-ingilizce/r\%C4\%B1z\%C4\%B1k Açmak http://tureng.com/tr/turkce-ingilizce/avu\%C3\%A7 Avuç http://tureng.com/tr/turkce-ingilizce/a\%C3\%A7mak Almak http://www.tdk.gov.tr/index.php?option=com_lehceler\&arama=lehceler\&guid=TDK.LH C.59806e6fe90526.22133333

Turkish Dialects official web page for TÜRK DİL KURUMU.

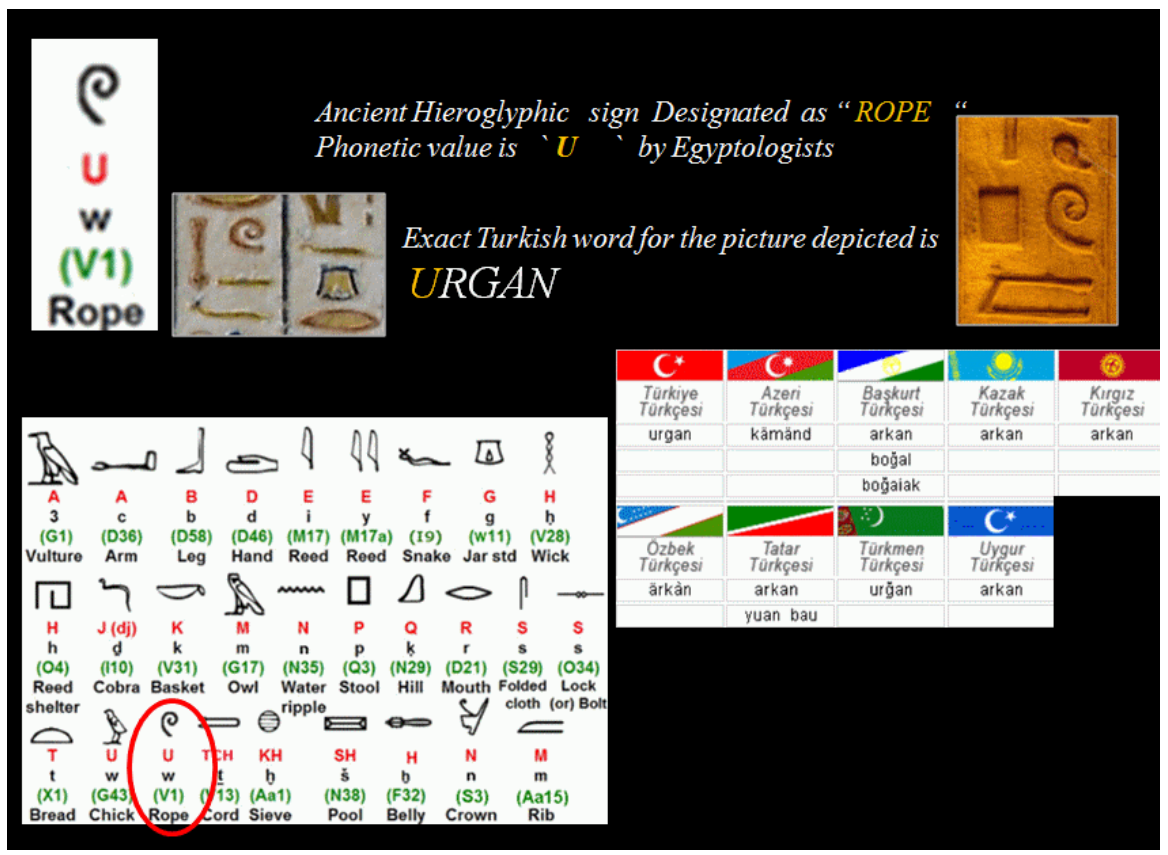

Picture 32. http://tureng.com/tr/turkce-ingilizce/urgan Urgan

http://www.tdk.gov.tr/index.php?option=com_lehceler\&arama=lehceler\&guid=TDK.LH C.59806e6fe90526.22133333

Turkish Dialects official web page for TÜRK DİL KURUMU. 


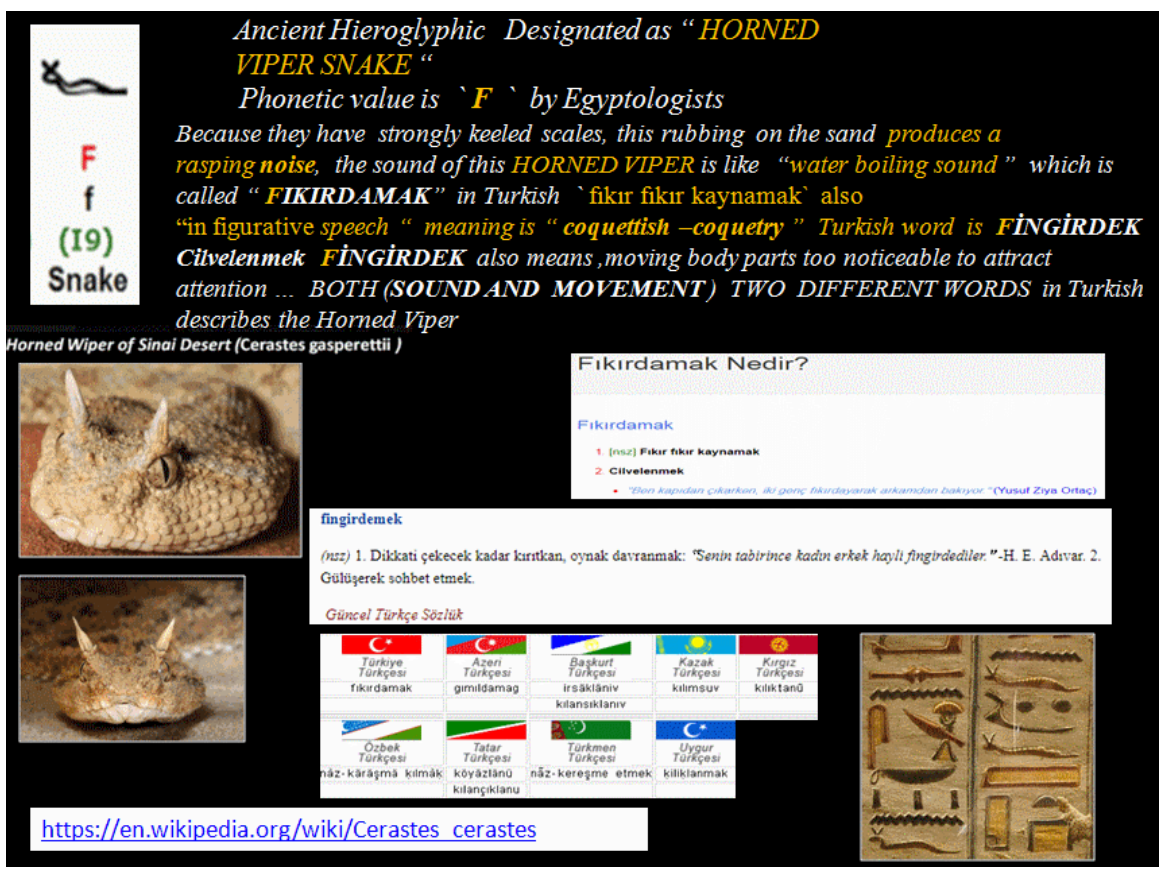

Picture 33. (https://www.youtube.com/watch?v=P70QzuEQ9hs Video "rasping noise of Horned Viper" Turkish sound like Water boiling sound called "FIKIRDAMAK". http://tureng.com/tr/turkce-ingilizce/f\%C4\%B1k\%C4\%B1rdamak Fikırdamak http://tureng.com/tr/turkce-ingilizce/fingirdemek Fingirdemek http://www.tdk.gov.tr/index.php?option=com_lehceler\&arama=lehceler\&guid=TDK.LH C.59806e6fe90526.22133333

Turkish Dialects official web page for TÜRK DİL KURUMU.
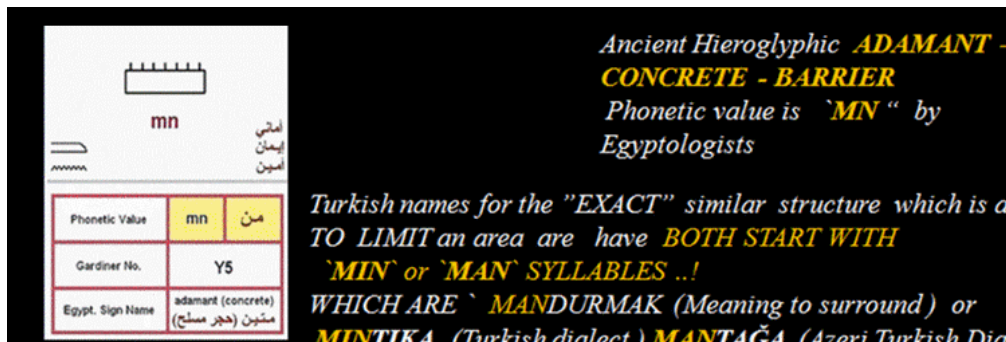

Turkish names for the "EXACT" similar structure which is a BARRIER TO LIMIT an area are have BOTH START WITH 'MIN' or 'MAN' SYLLABLES ...! WHICH ARE ' MANDURMAK (Meaning to surround) or MINTIKA (Turkish dialect) MANTA ĞA (Azeri Turkish Dialect)

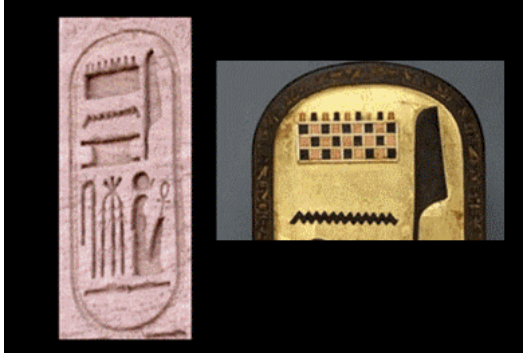

Amun Ramesses cartouche

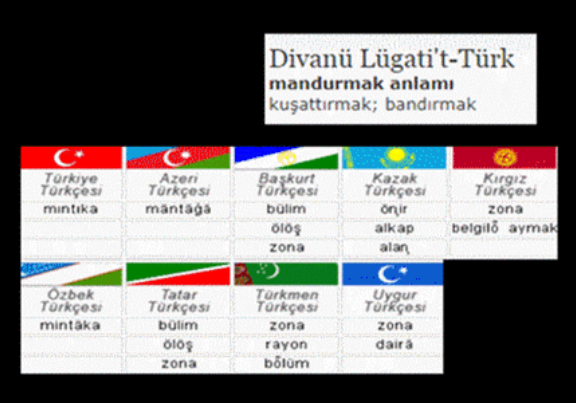

Picture 34. http://www.achiq.org/pitikler/dlt---.pdf Divanı Lügati’t Türk (Mandurmak) http://tureng.com/tr/turkce-ingilizce/m\%C4\%B1nt\%C4\%B1ka Mintıka http://www.tdk.gov.tr/index.php?option=com_lehceler\&arama=lehceler\&guid=TDK.LH C.59806e6fe90526.22133333

Turkish Dialects official web page for TÜRK DİL KURUMU. 


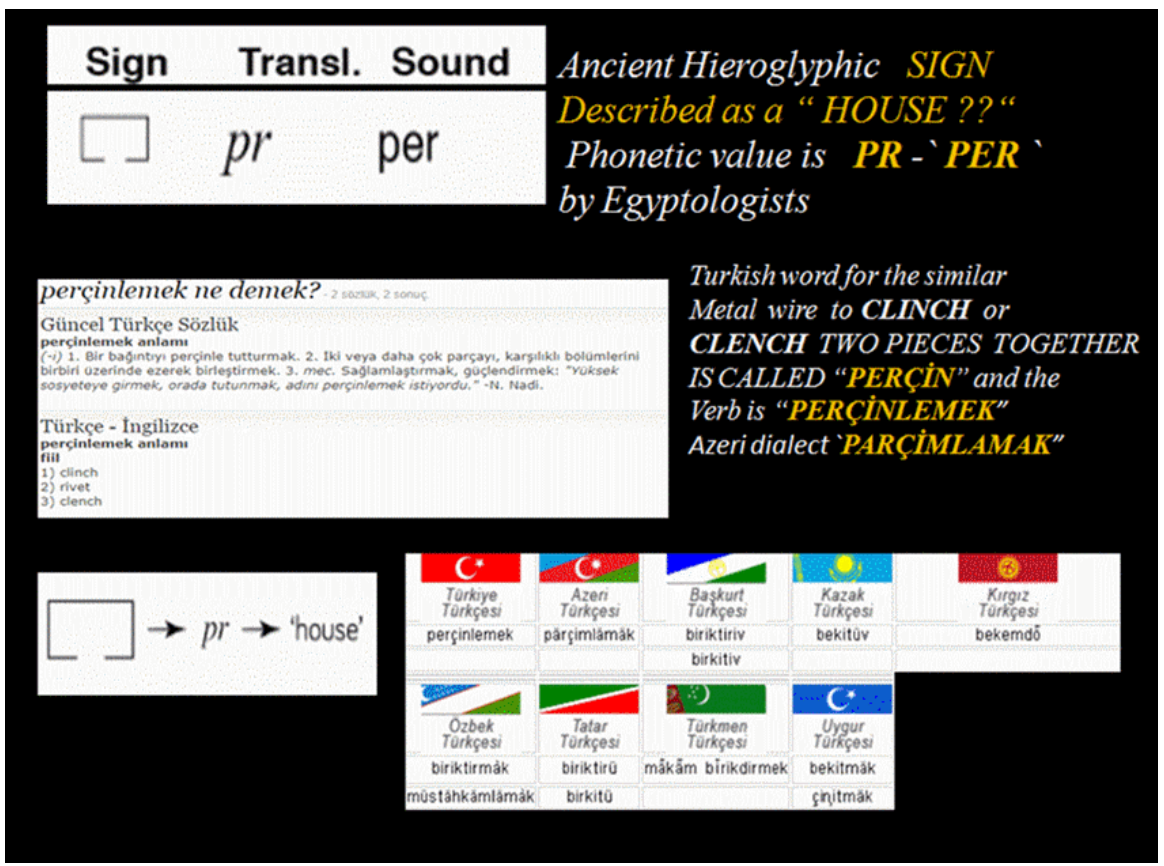

Picture 35. http://tureng.com/tr/turkce-ingilizce/per\%C3\%A7in Perçin

http://www.tdk.gov.tr/index.php?option=com_lehceler\&arama=lehceler\&guid=TDK.LH C.59806e6fe90526.22133333

Turkish Dialects official web page for TÜRK DİL KURUMU.

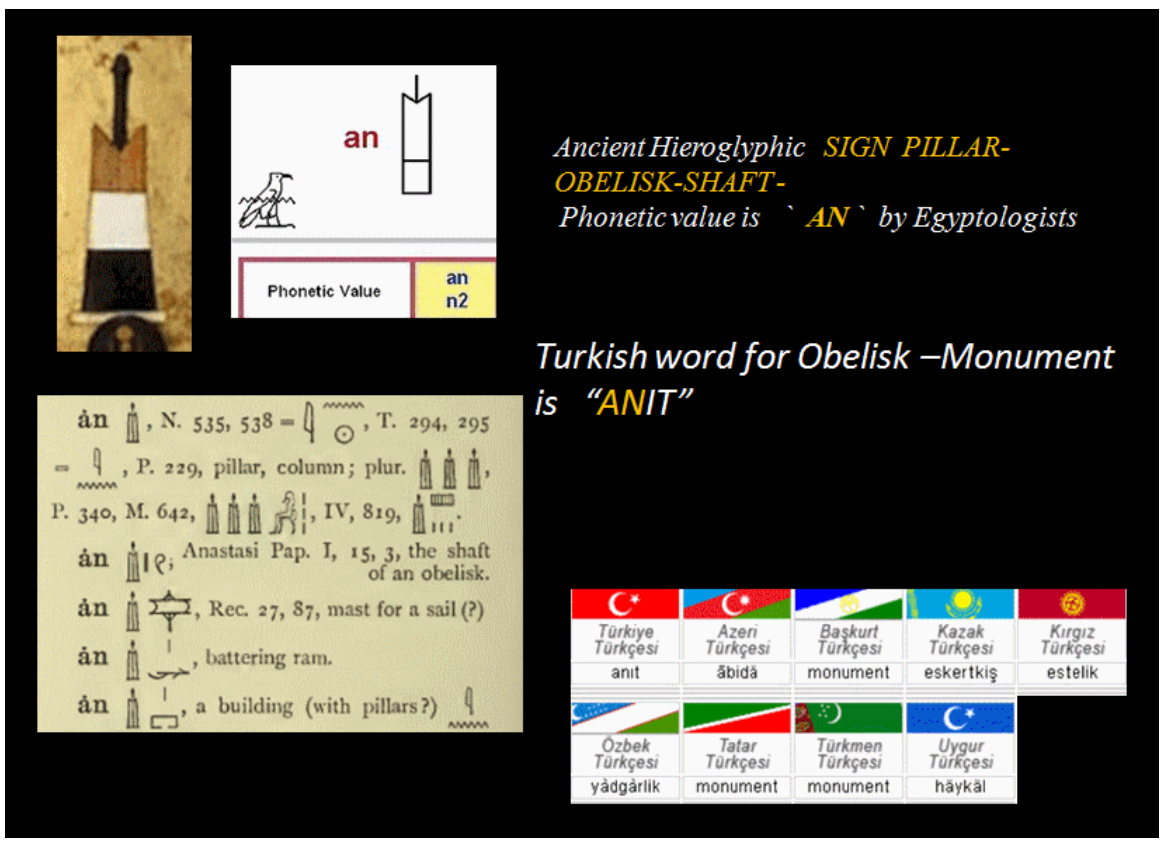

Picture 36. http://tureng.com/tr/turkce-ingilizce/an\%C4\%B1t Anit

http://www.tdk.gov.tr/index.php?option=com_lehceler\&arama=lehceler\&guid=TDK.LH C.59806e6fe90526.22133333

Turkish Dialects official web page for TÜRK DİL KURUMU

Bill, P. (2013) Hieroglyphic Sign List based on the work of Alan Gardiner Museum Tours Press, Littleton, Colorado ISBN 978-1-47749-059-4. 


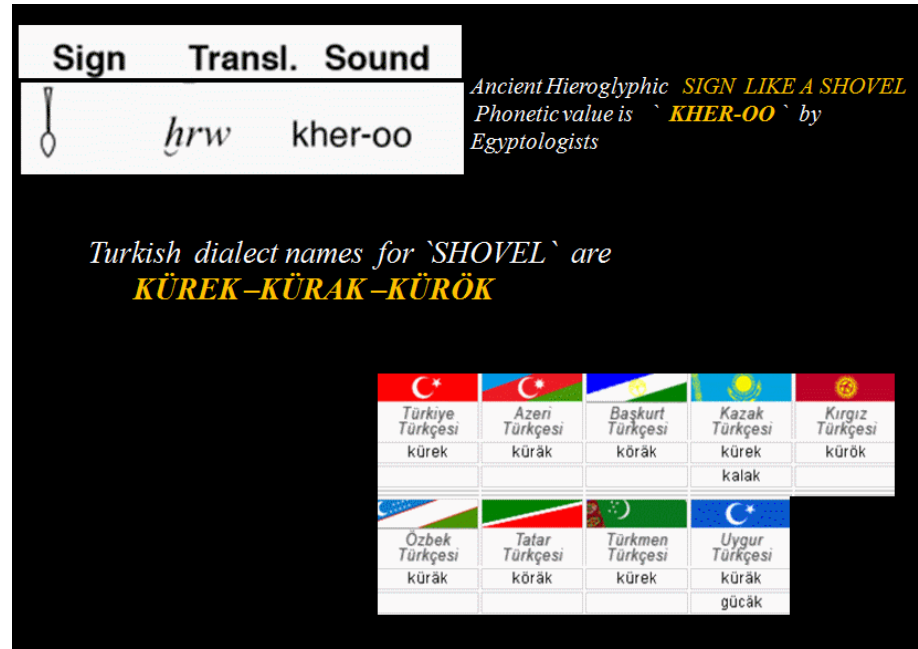

Picture 37. http://tureng.com/tr/turkce-ingilizce/k\%C3\%BCrek Kürek http://www.tdk.gov.tr/index.php?option=com_lehceler\&arama=lehceler\&guid=TDK.LH C.59806e6fe90526.22133333

Turkish Dialects official web page for TÜRK DİL KURUMU

Bill,P. (2013) Hieroglyphic Sign List based on the work of Alan Gardiner Museum Tours Press, Littleton,Colorado ISBN 978-1-47749-059-4

SAMPLES FROM Alsaadawi's $\left({ }^{*}\right)$ EGYPTIAN HIEROGLYPHIC DICTIONARY

$\left.{ }^{* *}\right)$ http://egyptology.tutatuta.com/operations/Dictio nary_A.htm

The samples I attached are "self explanatory", in other words the "Phonetic values and the meaning of the complex Hieroglyphic Group of Pictures" are "exactly matches with the Turkish Meaning of the Sentence", word by word.

Original samples are at these links specifically

http://egyptology.tutatuta.com/Als-dictionary/Als-D28-ka-ak.jpg

http://egyptology.tutatuta.com/Als-dictionary/Als-D18-dn-nd.jpg.

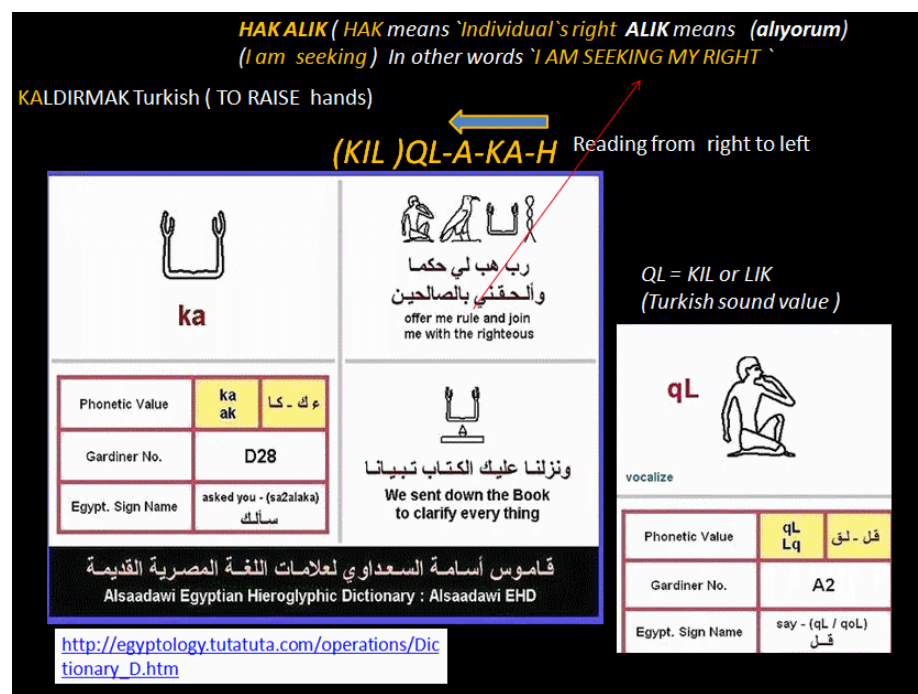

Picture 38. http://egyptology.tutatuta.com/operations/Dictionary_S.htm

Alsaadawi's Egyptian Hieroglyphic Dictionary

http://tureng.com/tr/turkce-ingilizce/kald\%C4\%B1rmak Kaldırmak

http://tureng.com/tr/turkce-ingilizce/hak\%20aramak Hak Aramak

http://www.tdk.gov.tr/index.php?option=com_lehceler\&arama=lehceler\&guid=TDK.LH

C.59806e6fe90526.22133333 Turkish Dialects official web page for TÜRK DİL KURUMU. 


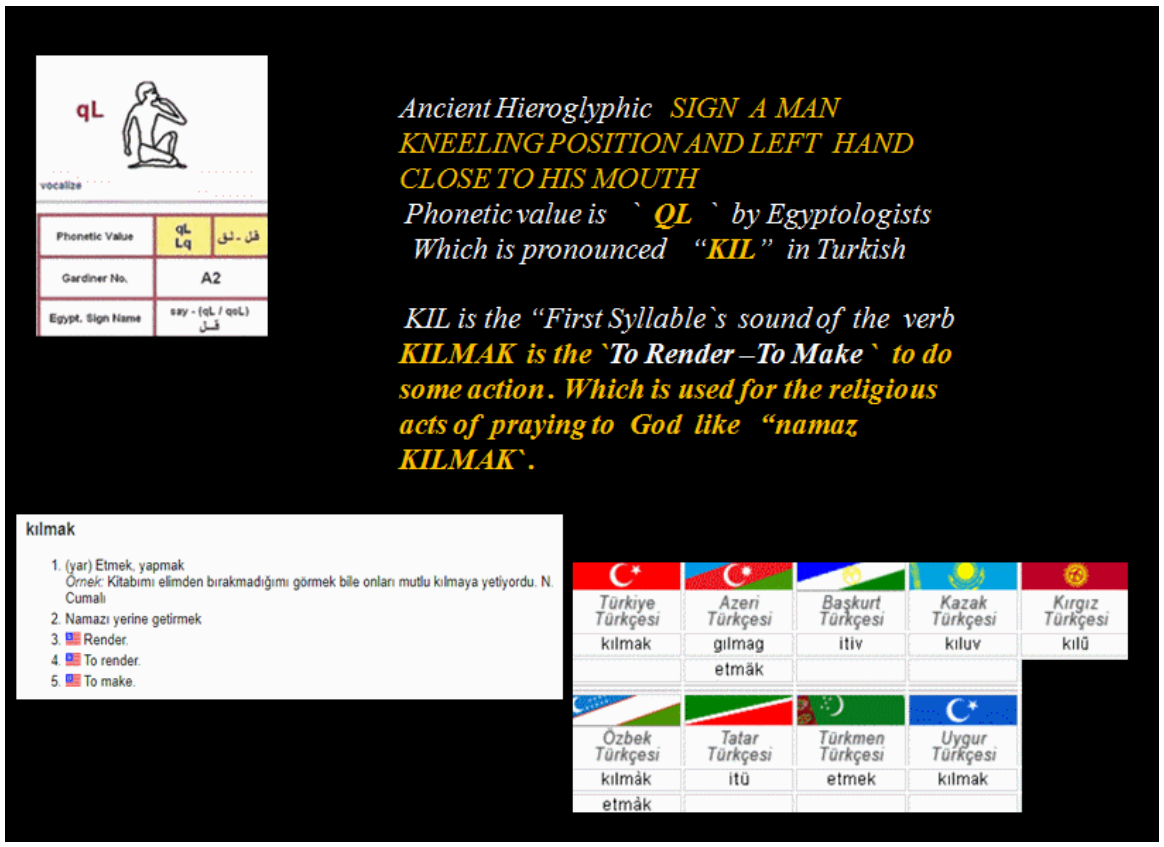

Picture 39. http://egyptology.tutatuta.com/operations/Dictionary_S.htm Alsaadawi's Egyptian Hieroglyphic Dictionary http://tureng.com/tr/turkce-ingilizce/k\%C4\%B1lmak Kılmak http://www.tdk.gov.tr/index.php?option=com_lehceler\&arama=lehceler\&guid=TDK.LH C.59806e6fe90526.22133333 Turkish Dialects official web page for TÜRK DİL KURUMU.

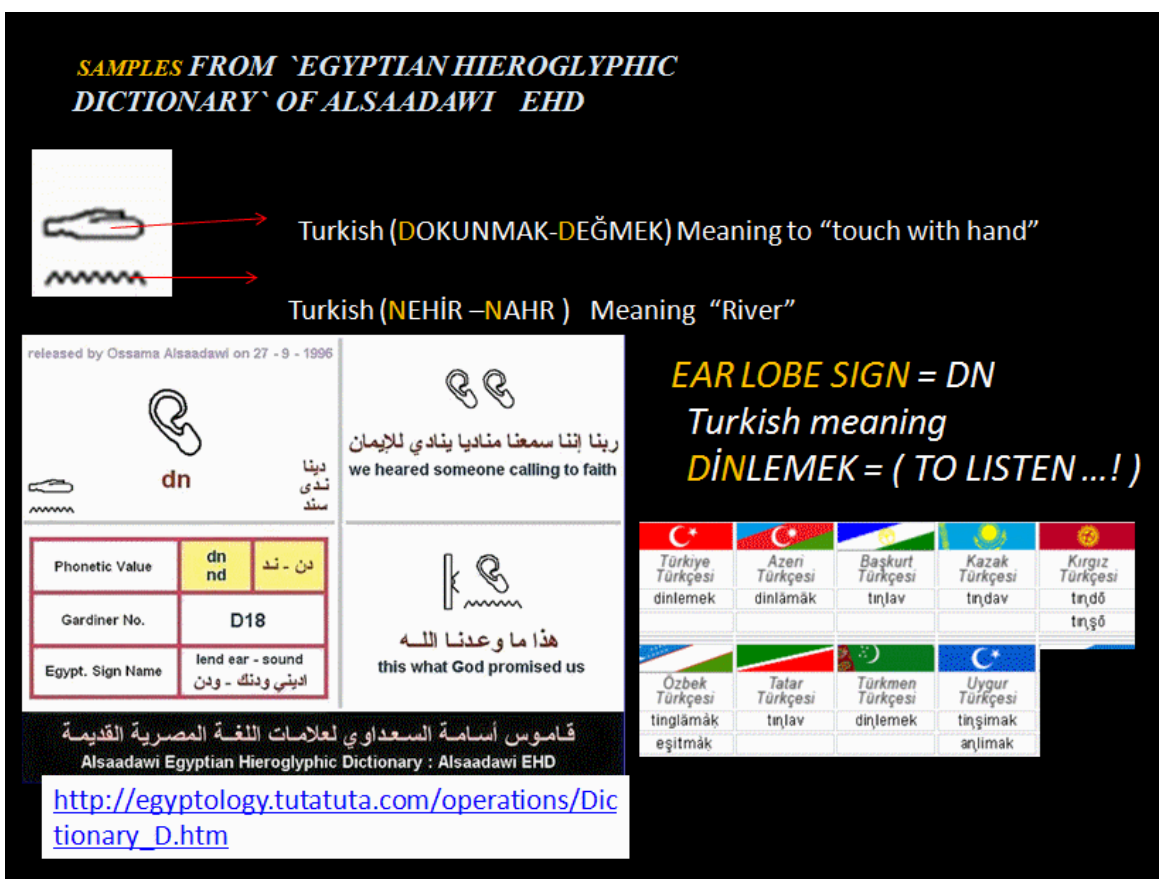

Picture 40. http://egyptology.tutatuta.com/operations/Dictionary_S.htm Alsaadawi's Egyptian Hieroglyphic Dictionary http://tureng.com/tr/turkce-ingilizce/dinlemek Dinlemek

http://www.tdk.gov.tr/index.php?option=com_lehceler\&arama=lehceler\&guid=TDK.LH C.59806e6fe90526.22133333

Turkish Dialects official web page for TÜRK DİL KURUMU. 
THE BIRTH TITTLE OF PHARAOH STARTS WITH ANKH+DUCK+SUN GOD RA SYMBOL

PHONETICALLY READ FROM LEFT TO RIGHT BECAUSE THE DUCK IS LOOKING TO THE LEFT...

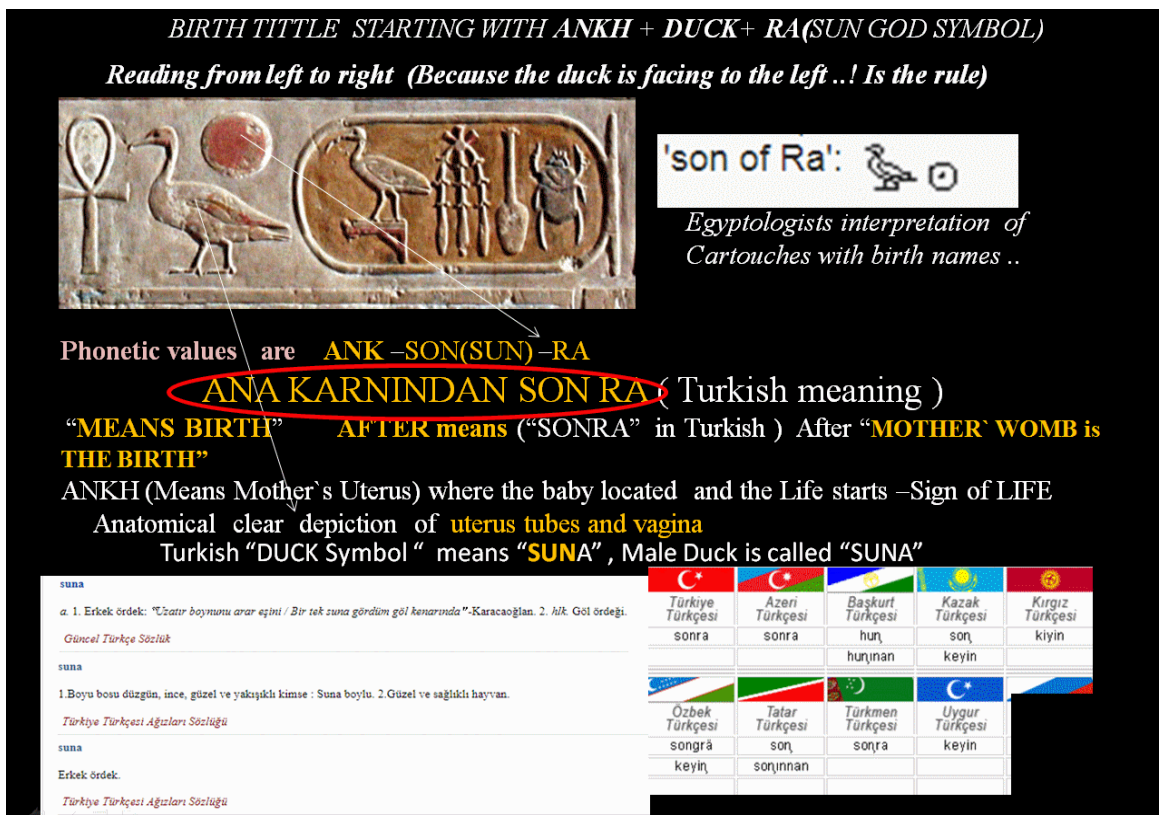

Picture 41. http://tureng.com/tr/turkce-ingilizce/ana\%20karn\%C4\%B1 Ana karn http://tureng.com/tr/turkce-ingilizce/suna SUNA http://tureng.com/tr/turkce-ingilizce/sonra SONRA(After) http://www.tdk.gov.tr/index.php?option=com_lehceler\&arama=lehceler\&guid=TDK.LH C.59806e6fe 90526.22133333

Turkish Dialects official web page for TÜRK DİL KURUMU.

Specifically the Pharaohs are given two names, one at birth and the other after they are coroneted as Pharaoh.

The birth title "Cartouche" has this 3 symbols and the phonetic values arefrom left to right-ANKH +DUCK+ SUN GOD RA.

Since the Duck is looking towards the left hieroglyphs are read from left to right.

When we read the symbols phonetically' you get ANKH-SUN(SON)-RA.

Familiarity with the human anatomy makes it easy to understand the symbol, ancient Egyptians designed the ANKH symbol for the "LIFE GIVER", which is the MOTHER.

Turkish "mother" means "ANA" specifically the ANKH symbol is the anatomical description of mother's UTERUS +TUBES +VAGINA. Which is clear as intended to be understood by everybody in ancient Egypt what this symbol is all about. In other words ANKH (phonetically) is the depiction of ANA + KARNI (Karın means womb of the mother in this case), ANKH both as a symbol and as a phonetic value in Turkish represents mother's womb (ANA KARNI) $=$ ANKH. 
Turkish SUNA means "duck" an clearly represented as a "duck" by Egyptian hieroglyphs phonetic values are read as SUN or SON. RA is the symbol of SUN GOD and the "phonetic value" is read the same "ra".

The symbols before the birth title of Pharaohs cartouches (Ankh +Duck +Sun God Ra) is phonetically Turkish which is "ANA KARNINDAN SONRA" meaning "AFTER THE MOTHER'S WOMB" is the BIRTH.

Please see Picture 63 (ANKH symbol).

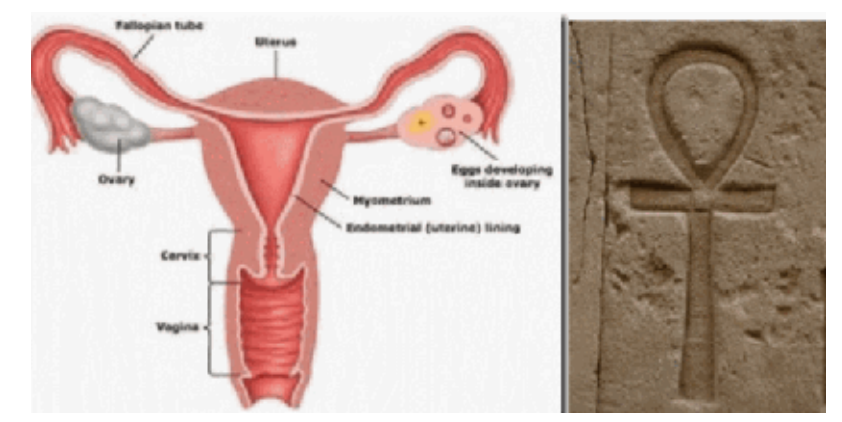

Picture 42. http://tureng.com/tr/turkce-ingilizce/ana Ana http://tureng.com/tr/turkce-ingilizce/ana\%20karn\%C4\%B1 Karın

\section{THE IMPORTANCE OF THE SUBJECT:}

The "phonetic values" of the hieroglyphic signs ancient Egyptians created for communication purpose are "preserved" thanks to smooth transition to Demotic and then Coptic language without loss of "phonetic values", Champollion was able to decipher them as they sounded thousands of years ago and "through currently spoken Turkish dialects" we can truly understand what they mean.

For example, "admittedly difficult and challenging hieroglyphic word samples" were brought up for consensus solution by the experts at an annual hieroglyphics convention, the experts tried to solve the several "key puzzles of the hieroglyphic words" and their true meanings at the "Louvre Stele", which is also called Irtysen Stele and it belongs to 2000 BC period.Other than the general idea what the subject matter is all about, they did know the meanings of the hieroglyphic words specific details at this link $\left.{ }^{* *}\right)$.

${ }^{* *}$ http://hercolano2.blogspot.no/2012/05/great-pyramid-pyramids-and-geopol ymers_6465.html

I picked these three words below, as an example; they were the "key puzzles" experts had difficulty figuring out the "true meanings" of the hieroglyphic words. (The pictures are below).

$1^{\text {st }}$ one was (reading from right to left since the animals are facing to the right) B-A-G-U(w)-N "something related with the construction by the Nile River" interpreted by the experts?

Phonetically Turkish word very close pronunciation of this Hieroglyphic word "as well as the subject matter" is the word "BAĞIN" which means when 
you are digging a trench for the construction you place two wooden boards or construct boards both side of the trench so the soil or the mud will not fill the trench you are digging in.

https://www.frmtr.com/muhendislik-mimarlik-peyzaj-mimarligi/4235929-mima ri-terimler-sozlugu.html Bağın

$2^{\text {nd }}$ one is (again read from right to left since the vultures looking to the right) H-A-A-T-N-U "somebody related-descended or progeny-" interpreted by the experts?

The Turkish word very close to that "pronunciation" as well as the subject matter is HATUNU, which means "official wife of someone"

http://tureng.com/tr/turkce-ingilizce/hatun Hatun

$3^{\text {rd }}$ one is read (from right to left) İri $\mathrm{d}(\mathrm{t})$ eymiyd(t)ü-"something related with a complement, embellishment, baked object or outward appearance?" was interpreted by the experts.

Very close pronunciation of this hieroglyphic word "as well as the subject" in today's Turkish is İri değil miydi?, meaning the question of "Wasn't that big in size?"

${ }^{* *}$ http://hercolano2.blogspot.com.tr/2012/05/great-pyramid-pyramids-and-ge opolymers_6465.html

http://tureng.com/tr/turkce-ingilizce/iri İri

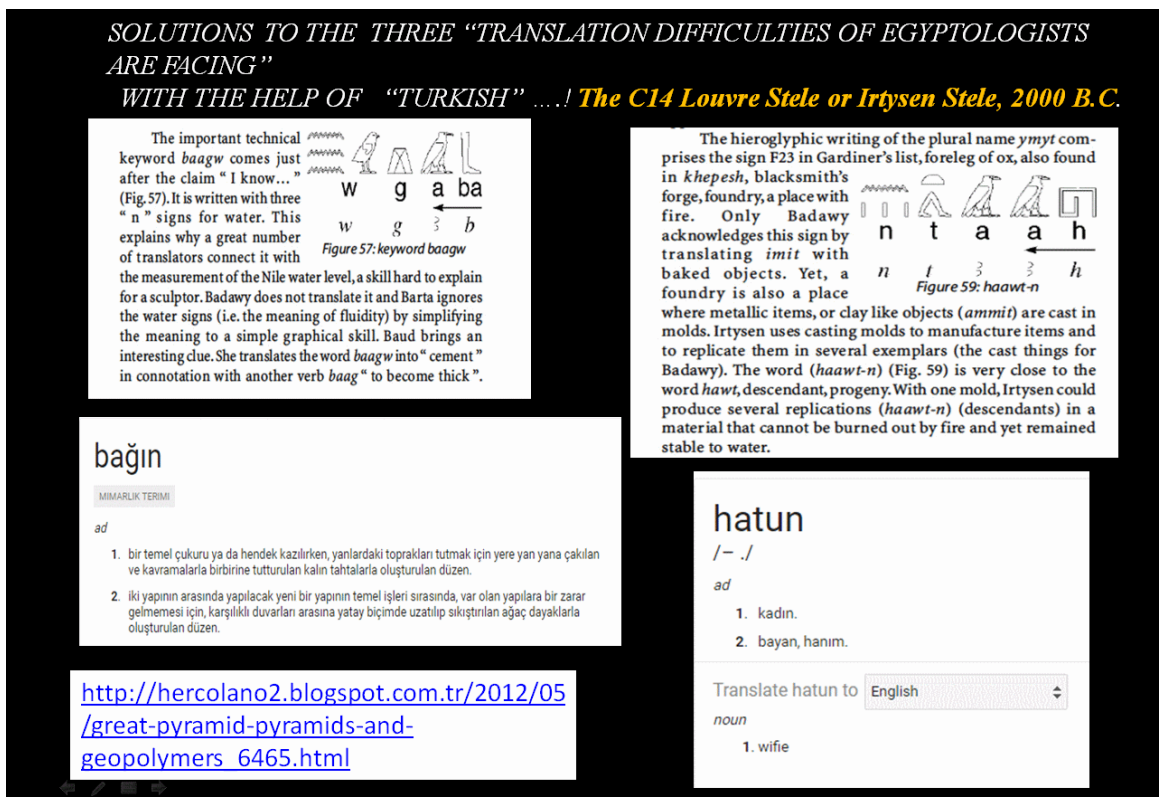

Picture 43.

http://hercolano2.blogspot.no/2012/05/great-pyramid-pyramids-and-geopolymers_6465. $\underline{\mathrm{html}}$

https://www.frmtr.com/muhendislik-mimarlik-peyzaj-mimarligi/4235929-mimari-teriml er-sozlugu.html Bağın

http://tureng.com/tr/turkce-ingilizce/hatun Hatun. 


\section{Iri $d(t)$ eymiyd(t)ü -TODAYS Turkish is 'iri değil miydi ? Meaning" Wasn 't that big in size}

One important technical keyword iritymyt comes just after the claim "I know" (Fig. 58). It comprises the verb irit (to make) and the complement ymyt, translated as amulets (Maspero), embellishments (Baud), things of paste (Wilson), baked object (Badawy) and outward appearance (Barta).

http://hercolano2.blogspot.com.tr/2012/05 Lgreat-pyramid-pyramids-andgeopolymers 6465.html

Picture 44.

http://hercolano2.blogspot.no/2012/05/great-pyramid-pyramids-and-geopolymers_6465. $\underline{\mathrm{html}}$

http://tureng.com/tr/turkce-ingilizce/iri İri.

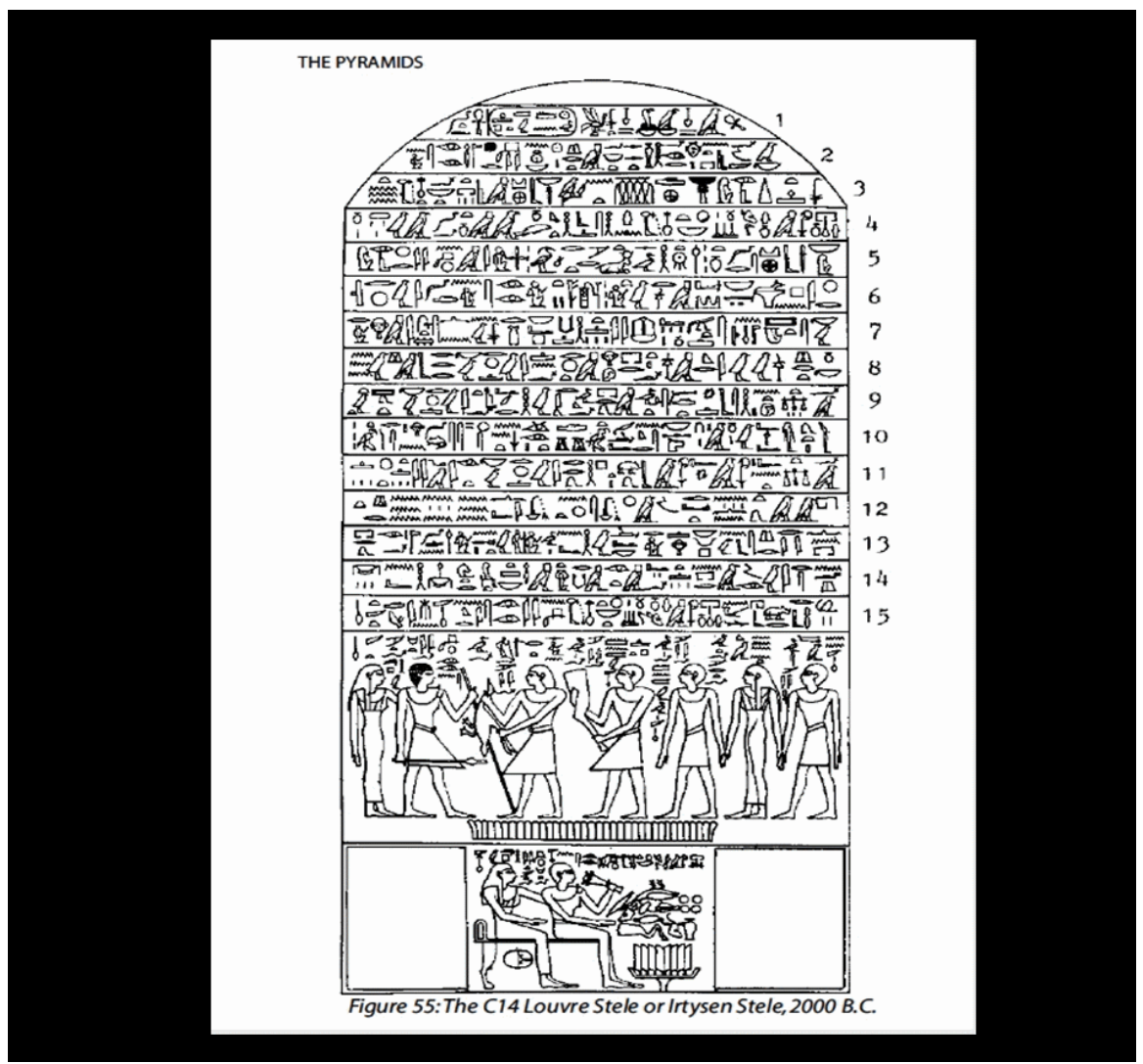

Picture 45.

http://hercolano2.blogspot.no/2012/05/great-pyramid-pyramids-and-geopolymers_6465. html. 


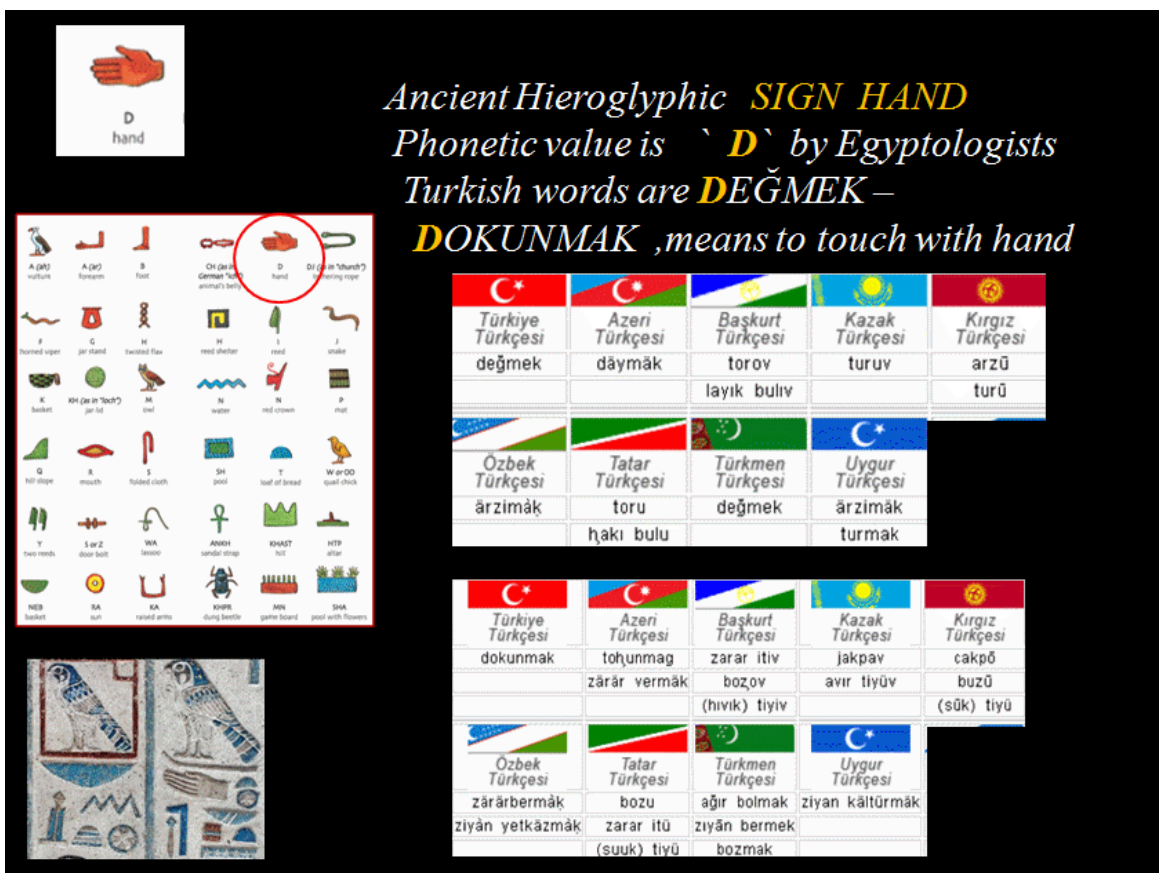

Picture 46. http://tureng.com/tr/turkce-ingilizce/de\%C4\%9Fmek Değmek http://tureng.com/tr/turkce-ingilizce/dokunmak Dokunmak

http://www.tdk.gov.tr/index.php?option=com_lehceler\&arama=lehceler\&guid=TDK.LH C.59806e6fe90526.22133333

Turkish Dialects official web page for TÜRK DİL KURUMU.

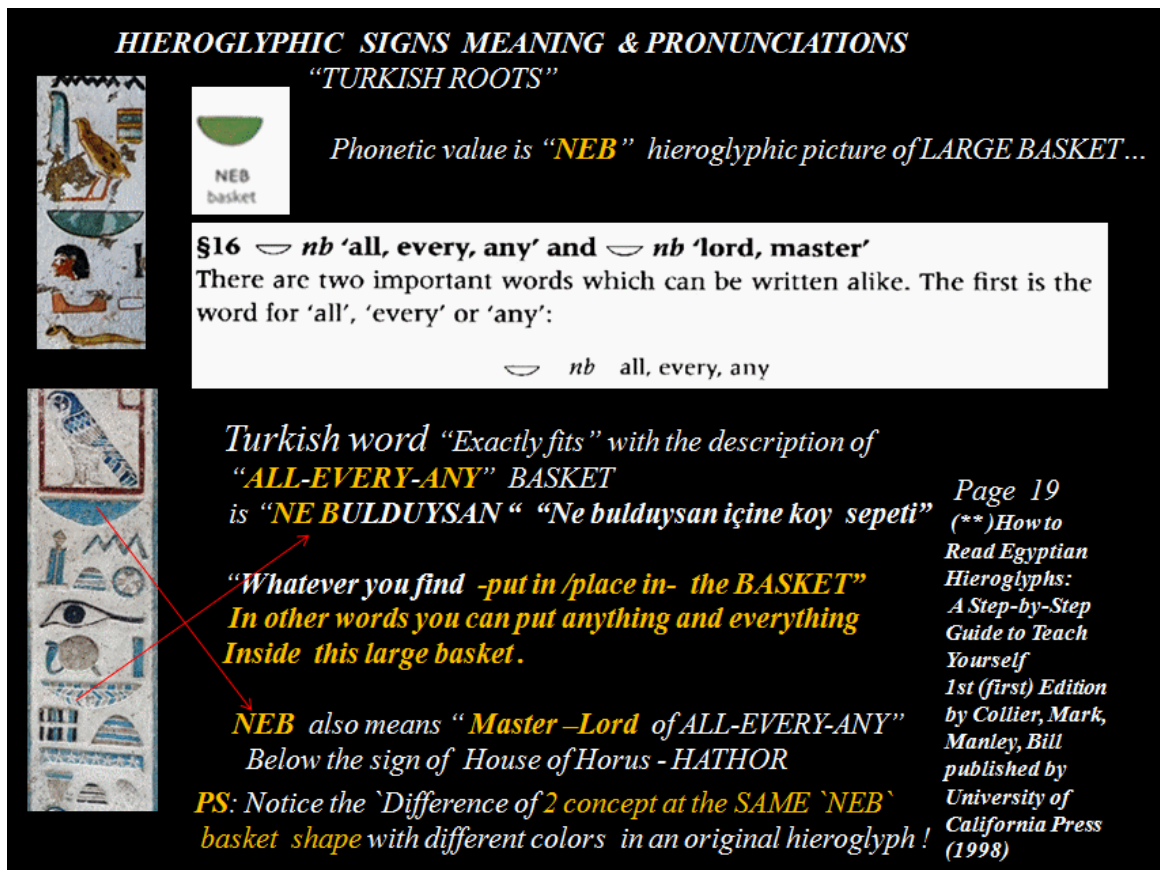

Picture 47. http://tureng.com/tr/turkce-ingilizce/ne\%20buldun? Ne Buldun?

Mark C., Bill M. How to read Egyptian Hieroglyphs, British Museum Press 1998 ISBN 0714119105

https://www.scribd.com/document/143680669/Collier-Mark-Bill-Manley-1998-How-to-R ead-Egyptian-Hieroglyphs. 
Egyptologists as well as experts have not much opinion about "Why the NEB basket given the phonetic value of NEB?" by ancient Egyptians, the phonetic value was confirmed by Champollion in 1822 through his Coptic language expertise.

I have to admit it was difficult to solve the puzzle, simply there is no Turkish word as a noun or as a verb starts with the "phonetic value of NEB" that fits the established rules created by ancient Egyptian priests with the large basket picture sign.

Solution came as I was reading an old book for the beginners, written by two experts on the hieroglyphic language, Mark Collier and Bill Manley $\left({ }^{*}\right)$.

NEB basket is a large basket of Hieroglyphic Sign and "represents 2 fundamental value".

a) Master-Lord and used together with the concept of Pharaohs and Egyptian Gods

b) It also represents ALL-EVERY-ANY "NEB" Phonetic value as well.(Page 19 of the Hieroglyphics book of Mark Collier and Bill Manley).

I have to point out important detail as a rule Egyptian hieroglyphs are read either starting from the right or from the left or from the top, based on the recognized rule where the animal pictures or certain signs are' facing towards', when you read "large basket of NEB sign" the "mirror image letters" you get the phonetic value of "BEN" which means "I am" "me" in Turkish (**), so this important distinction explains the designation of "Master-Lord" as well, it translates "I am the Master-Lord".

When I saw that "ALL-EVERY-ANY" concept I got the solution as well, why this basket has "phonetic value of NEB"...

It is "expression-idiom" in Turkish used to put "all-every-any" item you can imagine in a "common usage basket" and the term used for it is "NE BULDUYSAN KOY IÇİNE" meaning this basket will accommodate any which item you want to carry, I recalled Australian aboriginal women has very similar baskets made of tree barks and they carry everything with that basket-even new born babies!. They call it aboriginal Coolamon bowl ${ }^{* * *}$ ) (I attached the picture)

This basket is a very important item for the Australian aboriginal peoples daily lives,, similar baskets exists in African and Asian cultures for women they have been using these type of baskets in their everyday activities.

Ancient Egyptians also had "this type of basket" originating "tens of thousands of years ago" and the "Phonetic value" they gave to this unique basket is "Turkish expression-idiom", which is NE BULDUYSAN KOY IÇİNE SEPETI "whatever you have find" and "want to carry" put in this basket.

${ }^{*}$ )Mark C., Bill M. How to read Egyptian Hieroglyphs, British Museum Press 1998 ISBN 0714119105

https://www.scribd.com/document/143680669/Collier-Mark-Bill-Manley-1998How-to-Read-Egyptian-Hieroglyphs 
${ }^{* *}$ http://tureng.com/tr/turkce-ingilizce/ben Ben (I, me)

${ }^{(* *)}$ https://en.wikipedia.org/wiki/Coolamon_(vessel) Coolamon
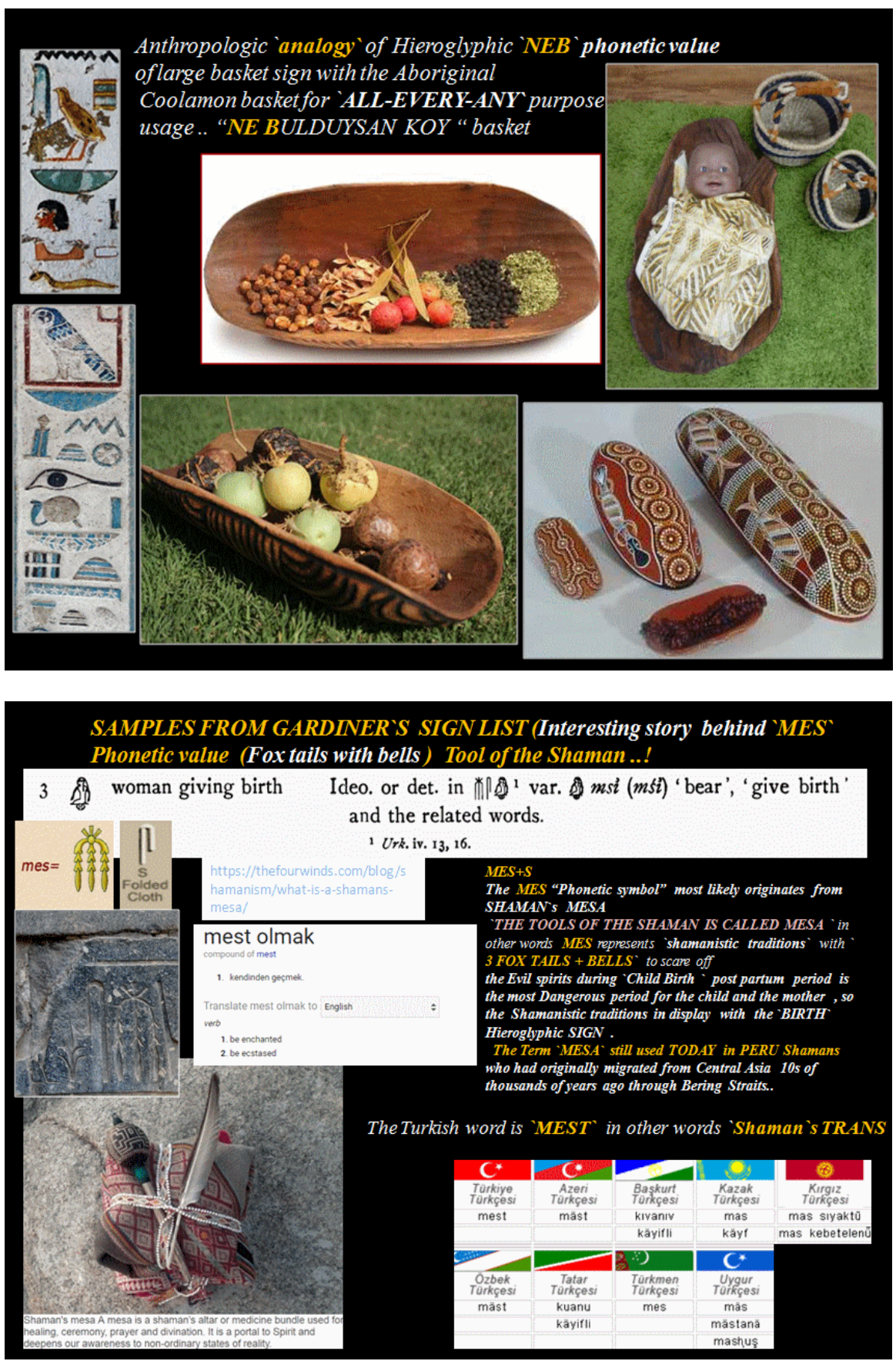

Picture 48. http://tureng.com/tr/turkce-ingilizce/mest\%20olma Mest, Mest olma

https://thefourwinds.com/blog/shamanism/what-is-a-shamans-mesa/ Shamanism, what is shaman's Mesa?

http://www.tdk.gov.tr/index.php?option=com_lehceler\&arama=lehceler\&guid=TDK.LH C.59806e6fe 90526.22133333

Turkish Dialects official web page for TÜRK DİL KURUMU

Bill, P. (2013) Hieroglyphic Sign List based on the work of Alan Gardiner Museum Tours Press, Littleton,Colorado ISBN 978-1-47749-059-4. 
THE ORIGIN OF "RA" (SUN GOD) PHONETIC VALUE

"RA" is the combination 2 WORDS INTO 1 short abbreviation

"Shortened form" of 2 different Hieroglyphic Signs and to join the Two concept together. . Happened during $5^{\text {th }} D Y N A S T Y$

The first word is Turkish RIZIK (RAZEKA) Shown as the Hieroglyphic Sign "OPEN MOUTH" Phonetic value " $R$ " Rizlk is a "Godly word" in other words "FOOD and DRINK" for sustenance of life given by the good graces of God..

The second word is "AVUÇAÇMAK" meaning "TO BEG"

"to OPEN HAND" "to ask".. The Hieroglyphic sign is

"EXTENDED HAND WITH

THE PALM OF HAND UPWARDS “

Turkish AVUÇ(Palm) Açmak (to open)

In other words RA is the "SUN GOD" who gives the sustenance

(food and drink) to those believers/followers who BEG from God In Turkish RIZIK ALMAK
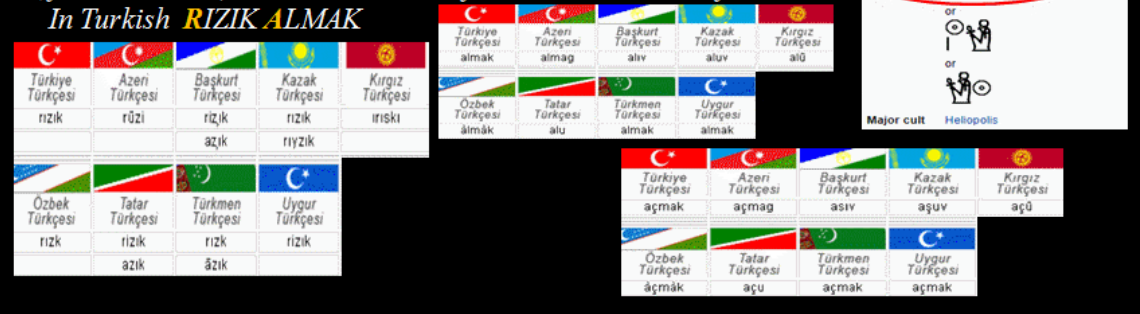

Picture 49. https://en.wikipedia.org/wiki/Ra God Ra

http://tureng.com/tr/turkce-ingilizce/r\%C4\%B1z\%C4\%B1k Rızık

http://tureng.com/tr/turkce-ingilizce/avu\%C3\%A7 Avuç

http://tureng.com/tr/turkce-ingilizce/a\%C3\%A7mak Açmak

http://www.tdk.gov.tr/index.php?option=com_lehceler\&arama=lehceler\&guid=TDK.LH C.59806e6fe90526.22133333

Turkish Dialects official web page for TÜRK DİL KURUMU.

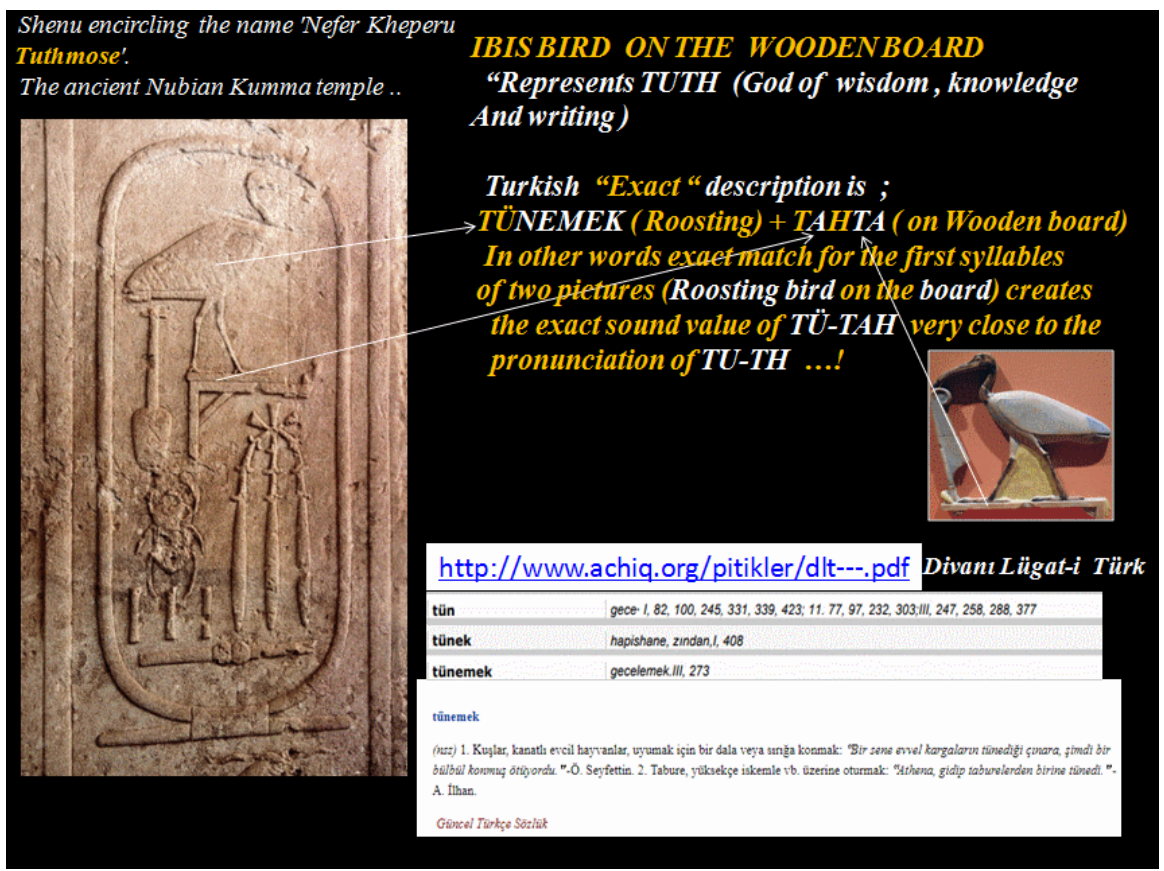

Picture 50. http://tureng.com/tr/turkce-ingilizce/t\%C3\%BCnemek Tünemek http://tureng.com/tr/turkce-ingilizce/tahta Tahta. 


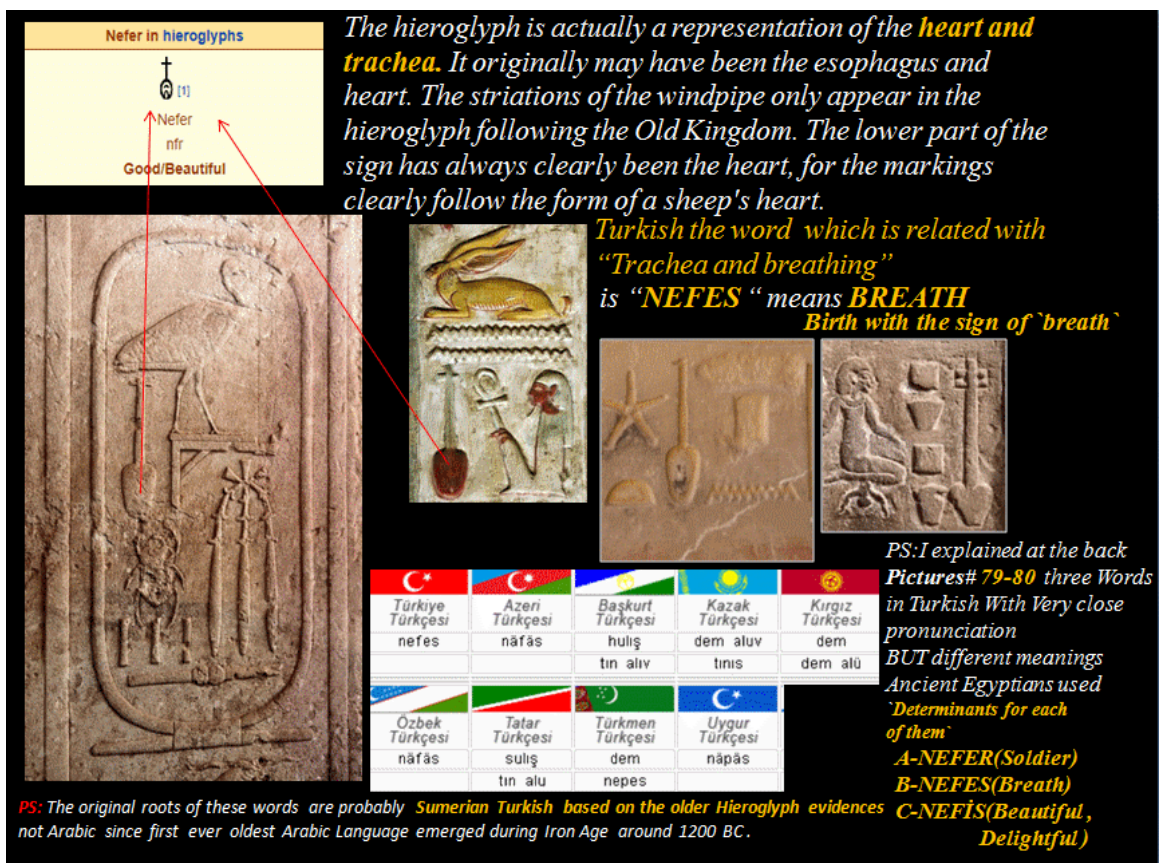

Picture 51. http://tureng.com/tr/turkce-ingilizce/nefer Nefer http://tureng.com/tr/turkce-ingilizce/nefes Nefes http://tureng.com/tr/turkce-ingilizce/nefis Nefis http://www.tdk.gov.tr/index.php?option=com_lehceler\&arama=lehceler\&guid=TDK.LH C.59806e6fe90526.22133333

Turkish Dialects official web page for TÜRK DİL KURUMU.

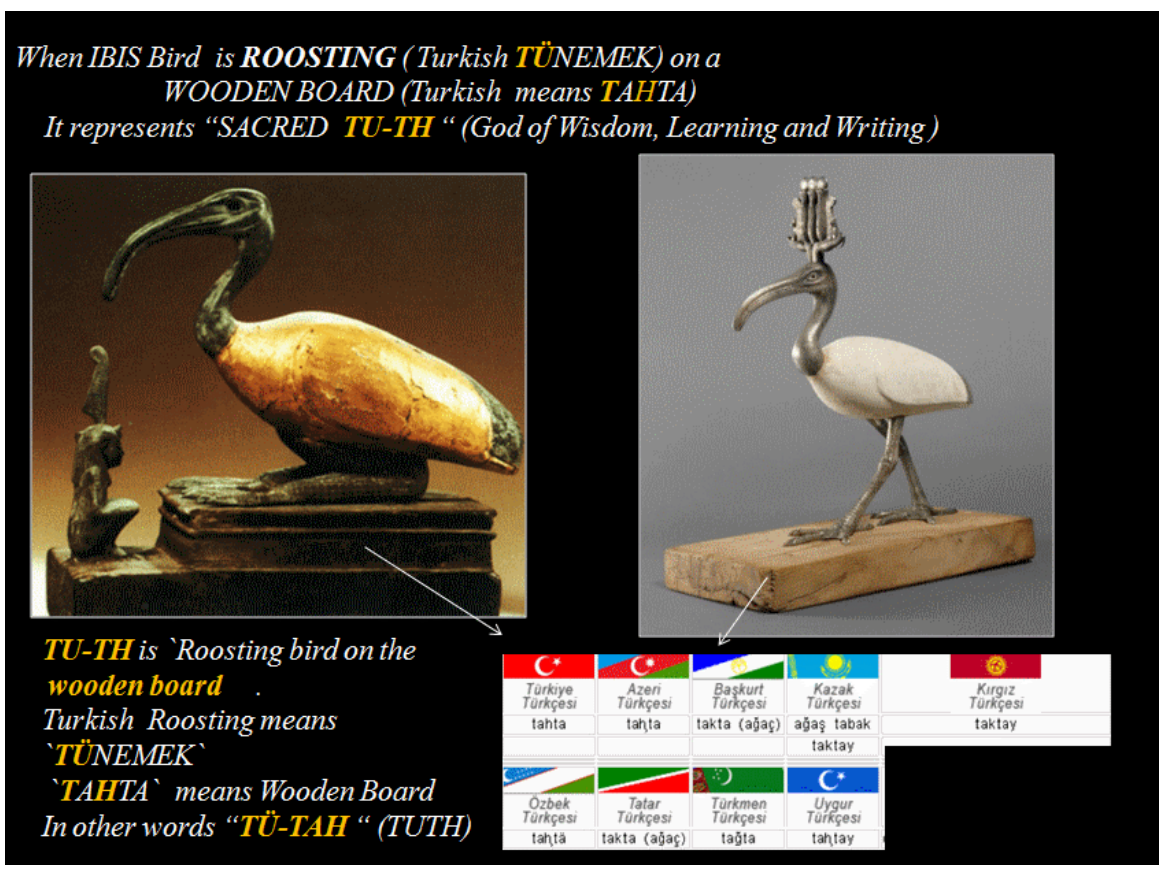

Picture 52. http://tureng.com/tr/turkce-ingilizce/t\%C3\%BCnemek Tünemek http://tureng.com/tr/turkce-ingilizce/tahta Tahta http://www.tdk.gov.tr/index.php?option=com_lehceler\&arama=lehceler\&guid=TDK.LH C.59806e6fe90526.22133333

Turkish Dialects official web page for TÜRK DİL KURUMU. 


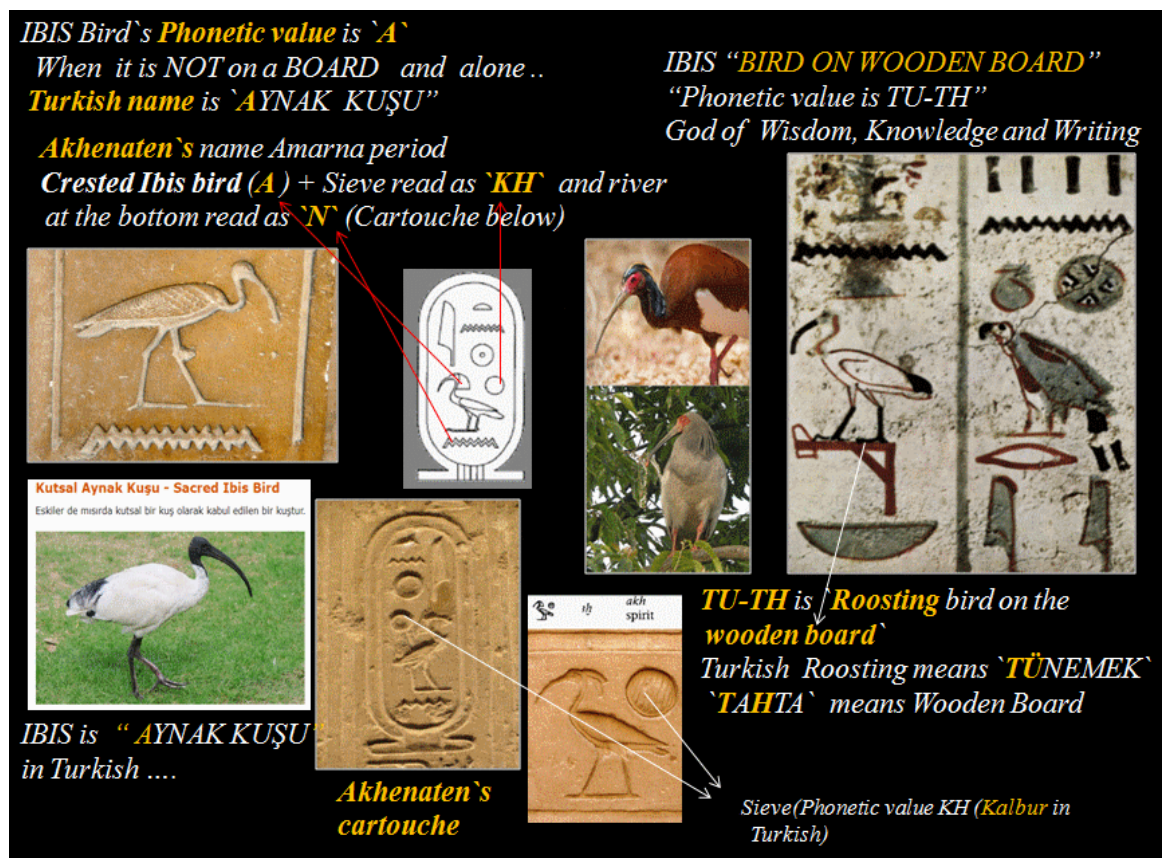

Picture 53. http://tureng.com/tr/turkce-ingilizce/t\%C3\%BCnemek Tünemek http://tureng.com/tr/turkce-ingilizce/tahta Tahta https://tr.wikipedia.org/wiki/Aynak Aynak-Ibis.

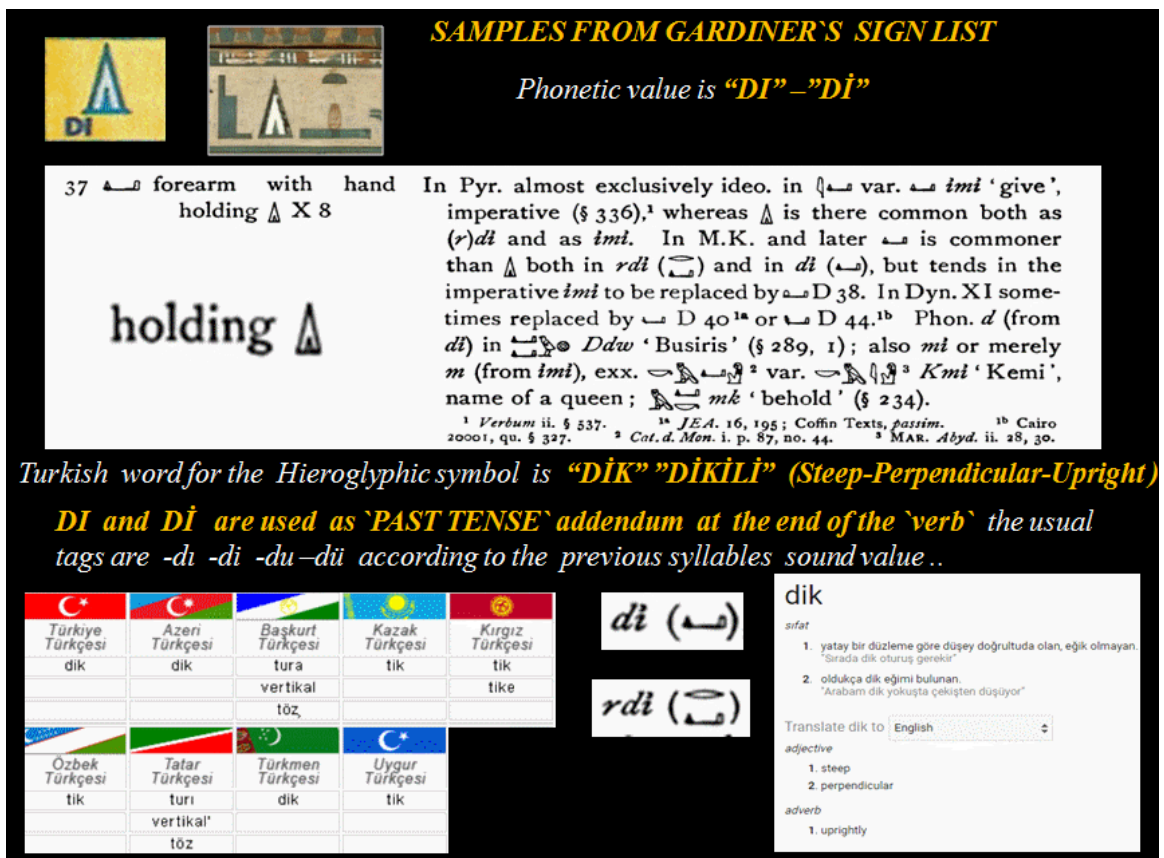

Picture 54. http://tureng.com/tr/turkce-ingilizce/dik Dik

Bill, P. (2013) Hieroglyphic Sign List based on the work of Alan Gardiner Museum Tours Press, Littleton,Colorado ISBN 978-1-47749-059-4

http://www.tdk.gov.tr/index.php?option=com_lehceler\&arama=lehceler\&guid=TDK.LH C.59806e6fe90526.22133333

Turkish Dialects official web page for TÜRK DİL KURUMU. 


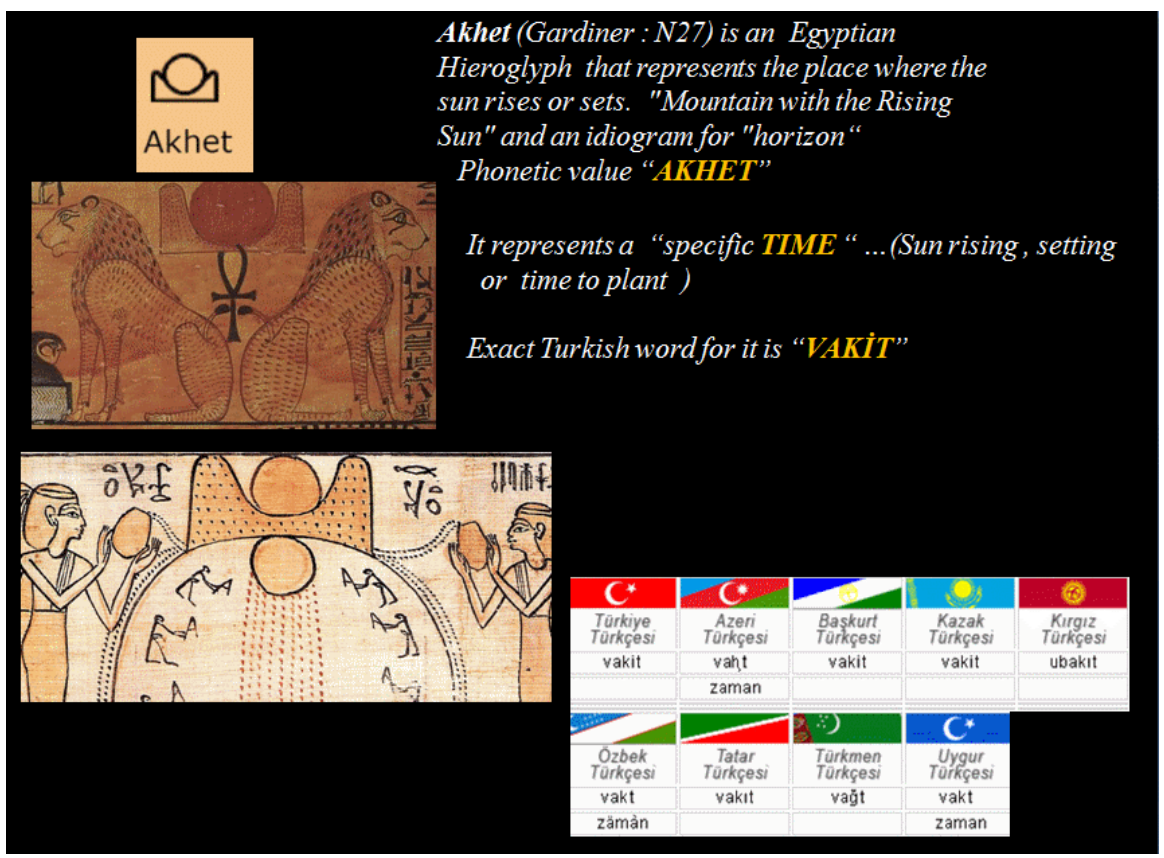

Picture 55. http://tureng.com/tr/turkce-ingilizce/vakit Vakit

http://www.tdk.gov.tr/index.php?option=com_lehceler\&arama=lehceler\&guid=TDK.LH C.59806e6fe90526.22133333

Turkish Dialects official web page for TÜRK DİL KURUMU.

\section{SAMPLES FROM GARDINER'S SIGNLIST}

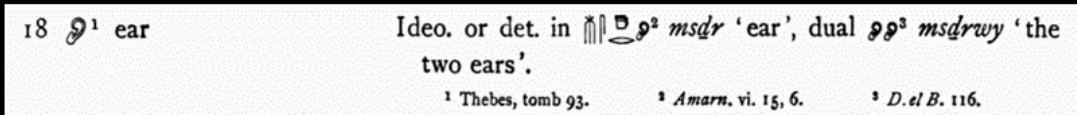

Mes (mas) $+S+d r$, Phonetic value "Masdr",

Turkish "close pronunciation" the verb which is related with EAR is "MAHZURDUR" Means THE PERSON is "DEAF" in one ear, if 2 ear sign than the person is deaf both ears.

mahzur ne demek? -2 sozzlak 2 sonut

Güncel Türkçe Sözlük

mahzur anlamı

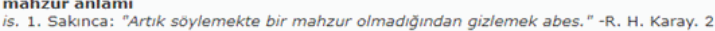

Engel.

Türkçe - İngilizce

mahzur anlamı

isim

) objection

disability

4) handicap

mahzur eş anlamlısı

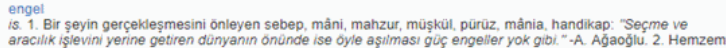

geçitlerde kara yolu guveniligini saǵlamak için kullanilan açlir kapanir duzenek, bariyer. 3. Herhangi bir yolu

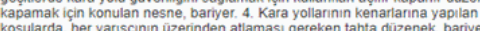

is Cekinilmesi, dikkatil olunması gereken, sakinmayı gerektiren durum, manzur. "Kabul etmekte bir sakince

Picture 56. http://tureng.com/tr/turkce-ingilizce/mahzur Hahzur

Bill, P. (2013) Hieroglyphic Sign List based on the work of Alan Gardiner Museum Tours Press, Littleton,Colorado ISBN 978-1-47749-059-4. 


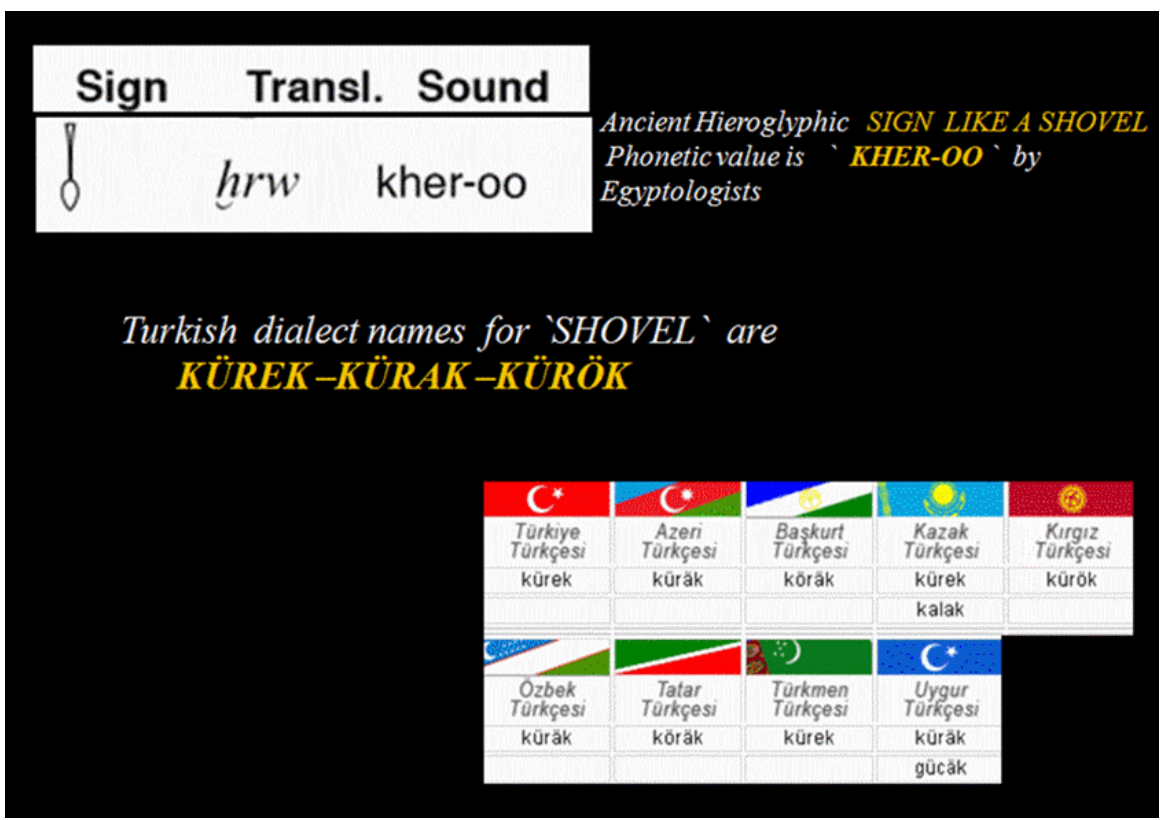

Picture 59. http://tureng.com/tr/turkce-ingilizce/k\%C3\%BCrek Kürek

Bill, P. (2013) Hieroglyphic Sign List based on the work of Alan Gardiner Museum Tours Press, Littleton,Colorado ISBN 978-1-47749-059-4

http://www.tdk.gov.tr/index.php?option=com_lehceler\&arama=lehceler\&guid=TDK.LH C.59806e6fe90526.22133333

Turkish Dialects official web page for TÜRK DİL KURUMU.

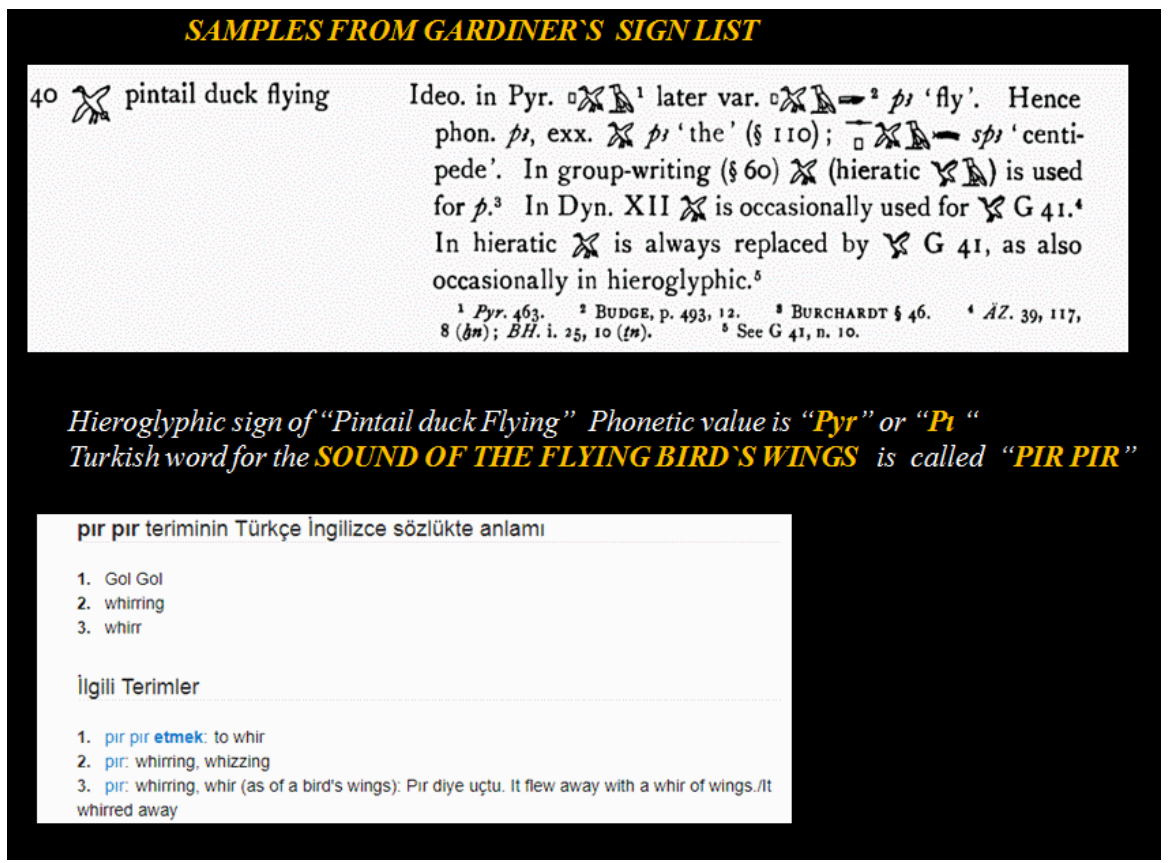

Picture 60. Bill, P. (2013) Hieroglyphic Sign List based on the work of Alan Gardiner Museum Tours Press, Littleton,Colorado ISBN 978-1-47749-059-4 http://tureng.com/tr/turkce-ingilizce/p\%C4\%B1r\%20p\%C4\%B1r Pir pir. 


\section{SAMPLES FROM GARDINER'S SIGNLIST}

$25 \odot$ two lips with teeth

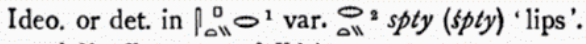
${ }^{1}$ M. u.K. ${ }_{4}$, 1 . Urk. iv. $971,2$.

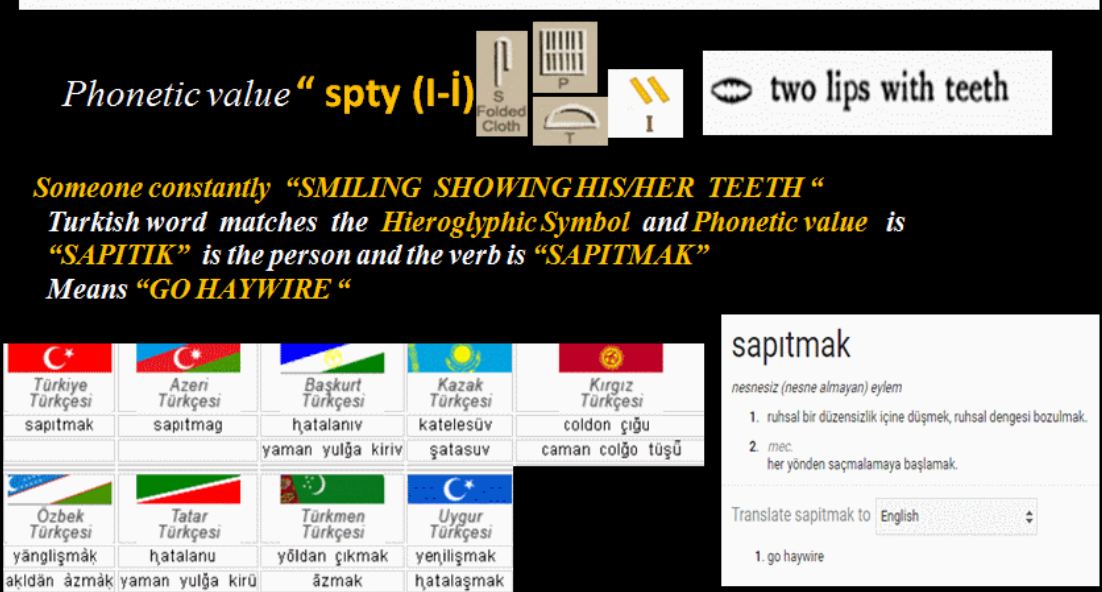

Picture 61. http://tureng.com/tr/turkce-ingilizce/sap\%C4\%B1tmak Sapitmak http://www.tdk.gov.tr/index.php?option=com_lehceler\&arama=lehceler\&guid=TDK.LH C.59806e6fe90526.22133333

Turkish Dialects official web page for TÜRK DİL KURUMU.

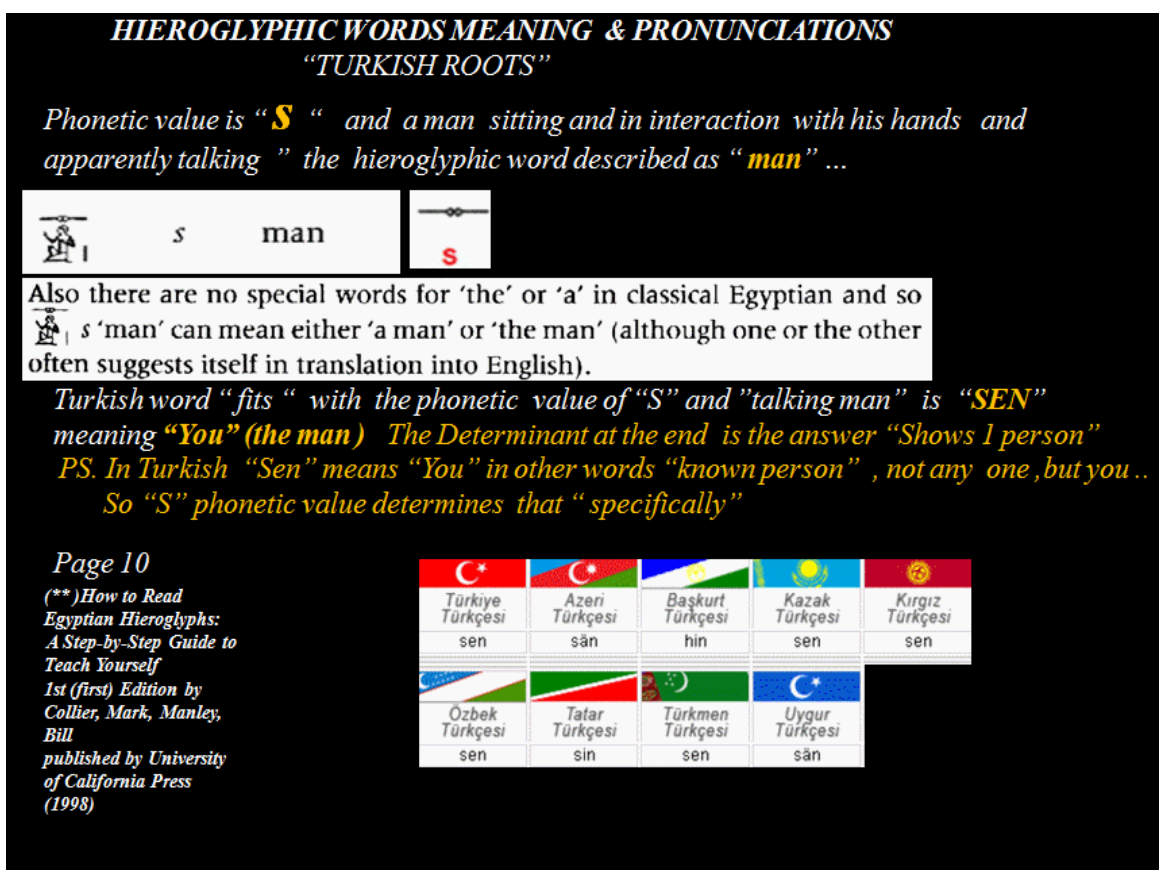

Picture 62. http://tureng.com/tr/turkce-ingilizce/sen Sen

Mark C., Bill M. How to read Egyptian Hieroglyphs, British Museum Press 1998 ISBN 0714119105

https://www.scribd.com/document/143680669/Collier-Mark-Bill-Manley-1998-How-to-R ead-Egyptian-Hieroglyphs

http://www.tdk.gov.tr/index.php?option=com_lehceler\&arama=lehceler\&guid=TDK.LHC $.59806 \mathrm{e} 6 \mathrm{fe} 90526.22133333$

Turkish Dialects official web page for TÜRK DİL KURUMU. 


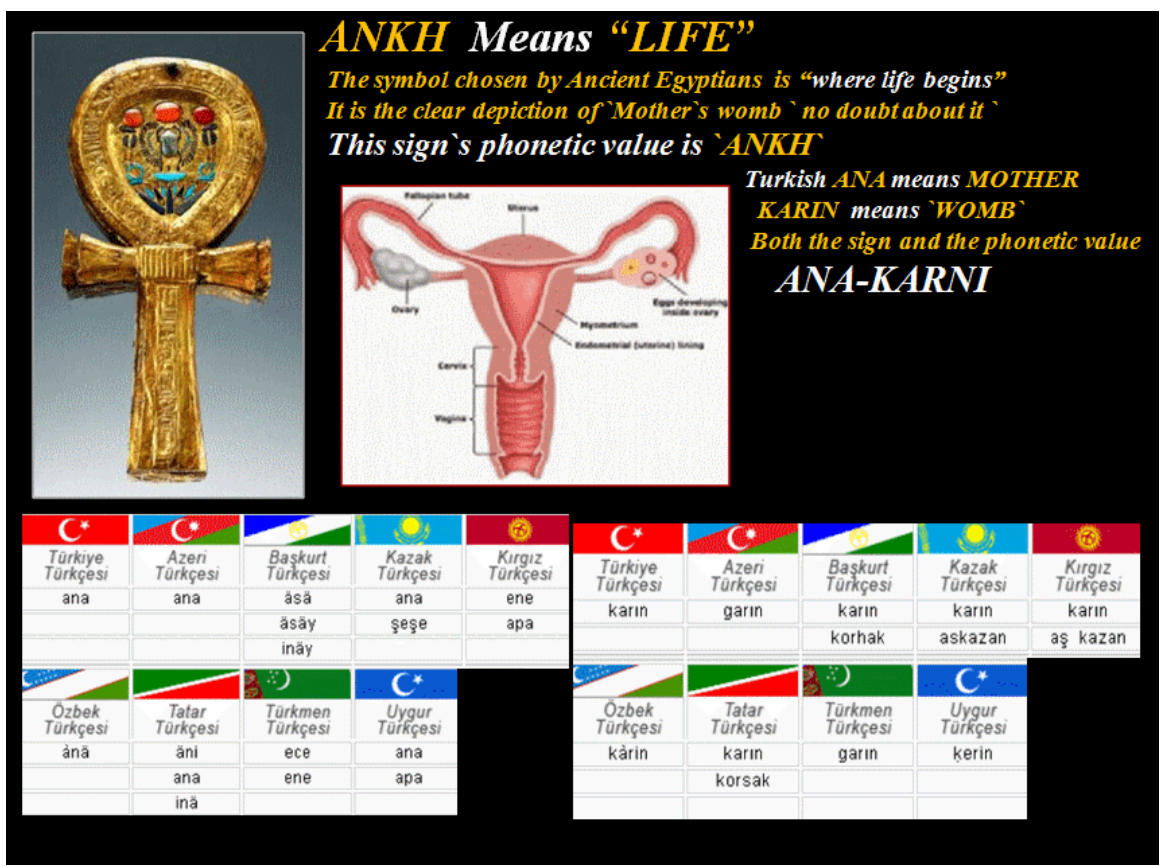

Picture 63. http://tureng.com/tr/turkce-ingilizce/ana\%20karn\%C4\%B1 Ana karnı http://tureng.com/tr/turkce-ingilizce/ana Ana

http://tureng.com/tr/turkce-ingilizce/ana\%20karn\%C4\%B1 Karın

http://www.tdk.gov.tr/index.php?option=com_lehceler\&arama=lehceler\&guid=TDK.LH C.59806e6fe90526.22133333

Turkish Dialects official web page for TÜRK DİL KURUMU.

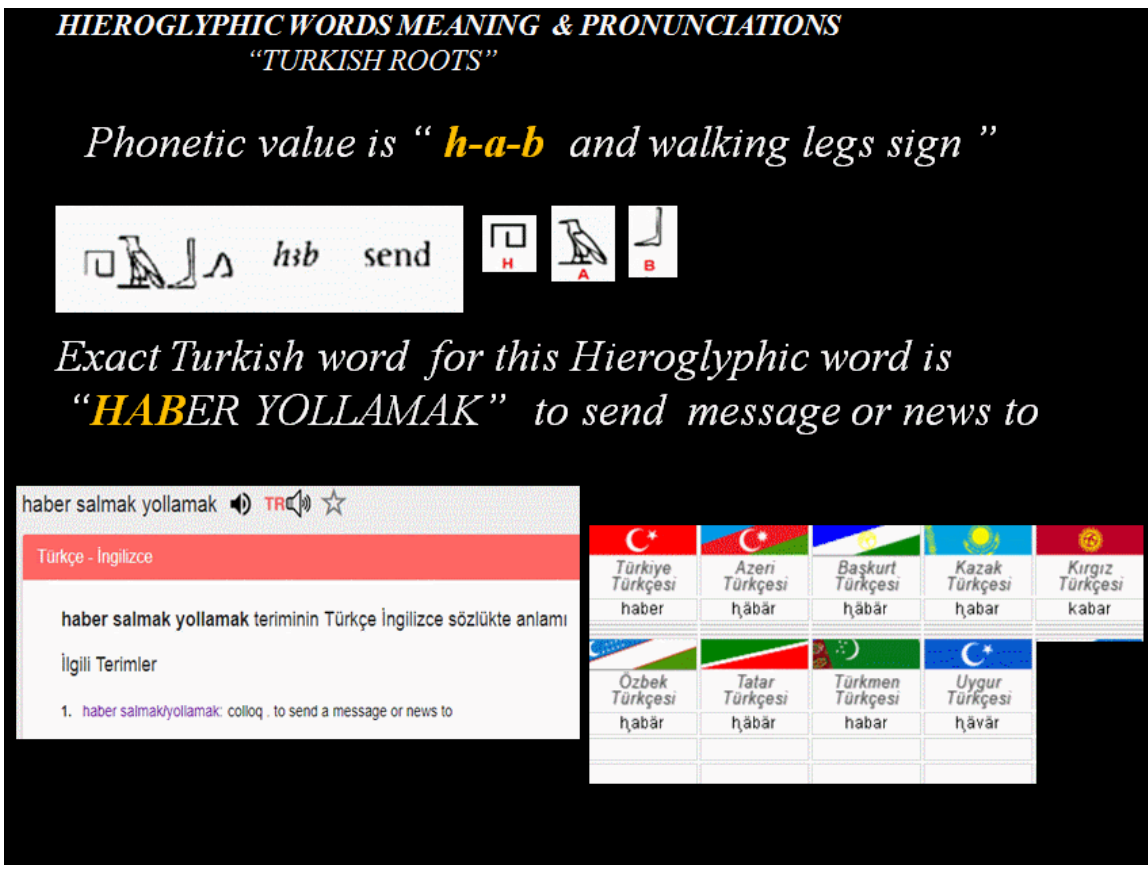

Picture 64. http://tureng.com/tr/turkce-ingilizce/haber\%20salmak Haber salmak http://www.tdk.gov.tr/index.php?option=com_lehceler\&arama=lehceler\&guid=TDK.LH C.59806e6fe90526.22133333

Turkish Dialects official web page for TÜRK DİL KURUMU. 


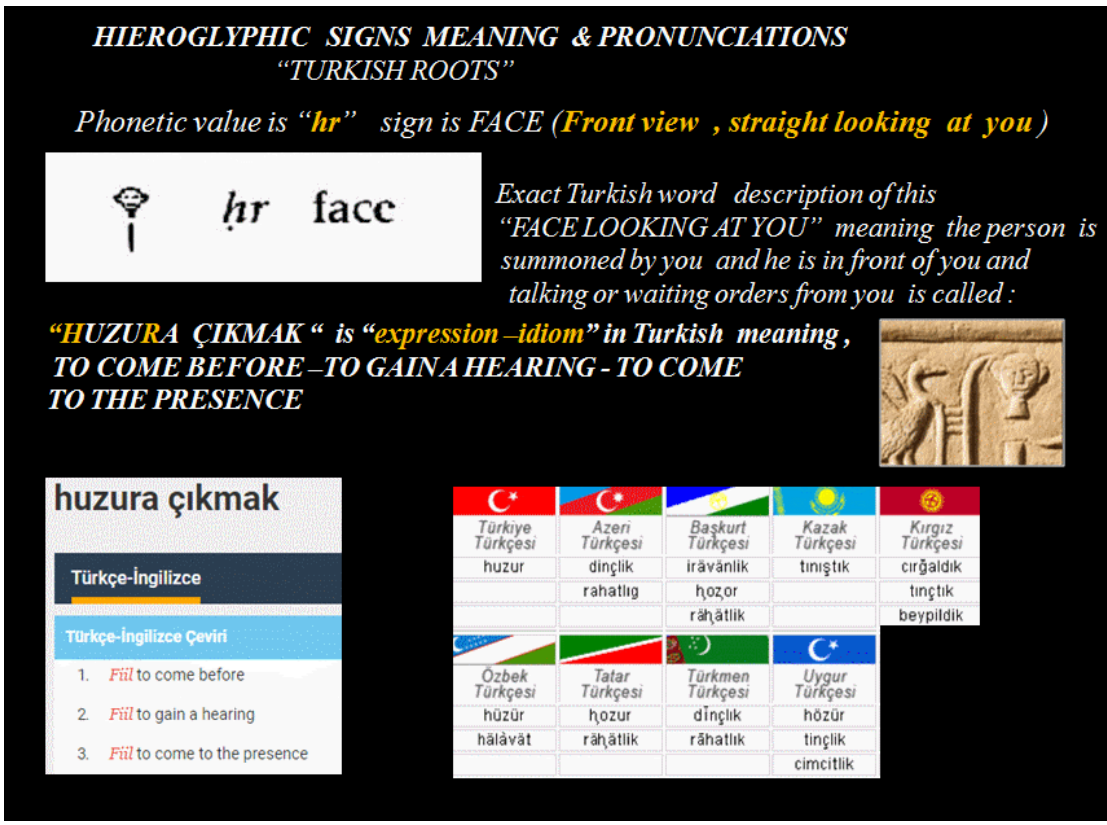

Picture 65. http://tureng.com/tr/turkce-ingilizce/huzuruna\%20\%C3\%A7\%C4\%B1kmak Huzura çımak

http://www.tdk.gov.tr/index.php?option=com_lehceler\&arama=lehceler\&guid=TDK.LH C.59806e6fe90526.22133333

Turkish Dialects official web page for TÜRK DİL KURUMU.

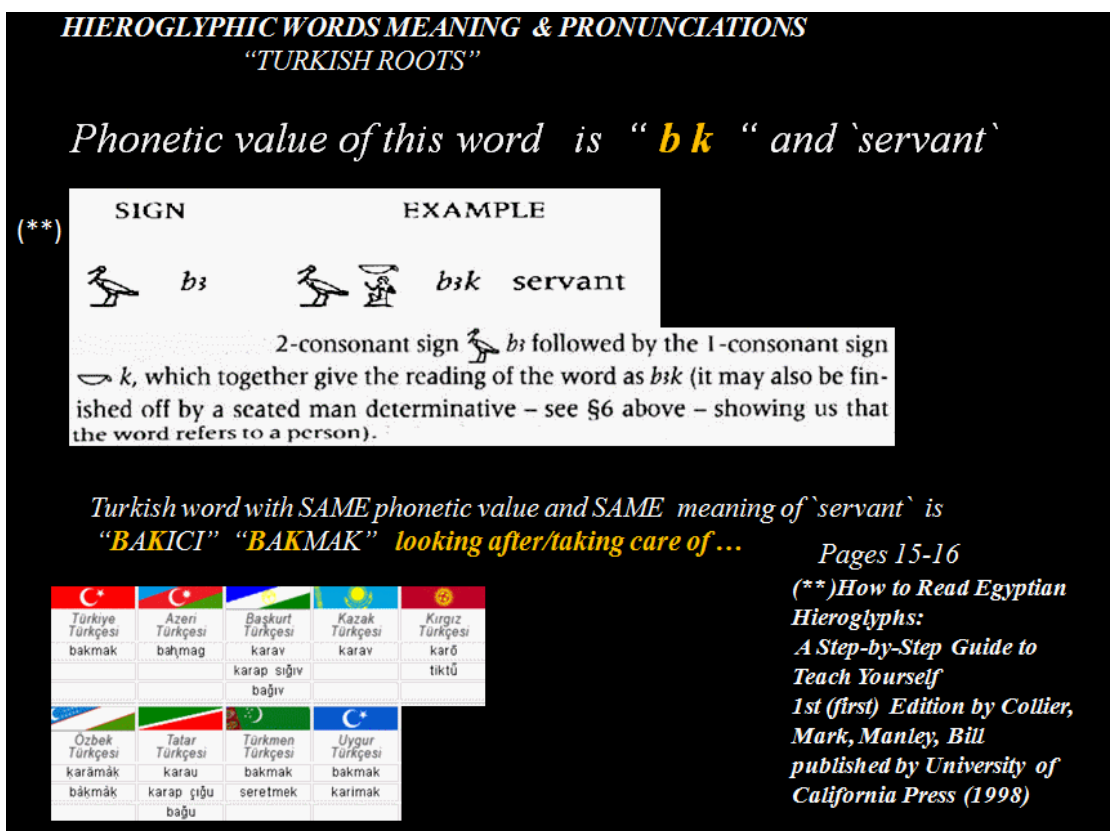

Picture 66. http://tureng.com/tr/turkce-ingilizce/bak\%C4\%B1c\%C4\%B1 Bakıc1 http://www.tdk.gov.tr/index.php?option=com_lehceler\&arama=lehceler\&guid=TDK.LH C.59806e6fe90526.22133333

Turkish Dialects official web page for TÜRK DİL KURUMU

Mark C., Bill M. How to read Egyptian Hieroglyphs, British Museum Press 1998 ISBN 0714119105

https://www.scribd.com/document/143680669/Collier-Mark-Bill-Manley-1998-How-to-R ead-Egyptian-Hieroglyphs. 


\section{HIEROGLYPHIC SIGN MEANING \& PRONUNCIATIONS}

Phonetic value of this sign is " krst" krst $\longmapsto$ burial

The word for the SAME MEANING and SAME Phonetic value is "KABRISTAN" entered to Turkish language from Arabic and Farsi ...

SS: This sign probably belong to "late period of hieroglyphic usage

kabristan Ar. ¿aabr + Far. -istün

a Mezarilik.

Gïncel Tïrke Sözlit

kabristan

(Ar: kabr (kuburir)+Far-istann) kabristan

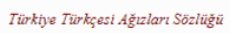

kabristan

Mezarlik

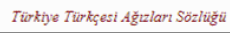

the "phonetic root of the word is Arabic as well as Farsi"

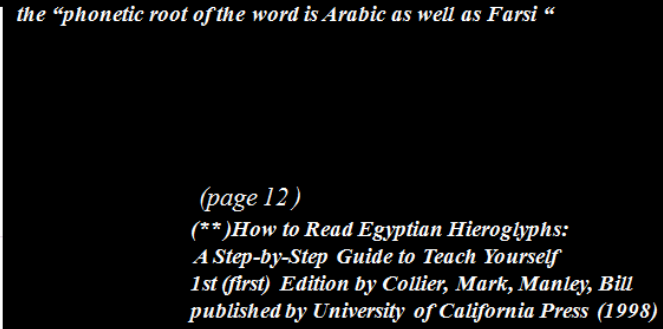

Picture 67. http://tureng.com/tr/turkce-ingilizce/kabristan Kabristan

http://www.tdk.gov.tr/index.php?option=com_lehceler\&arama=lehceler\&guid=TDK.LH C.59806e6fe90526.22133333

Turkish Dialects official web page for TÜRK DİL KURUMU

Mark C., Bill M. How to read Egyptian Hieroglyphs, British Museum Press 1998 ISBN 0714119105

https://www.scribd.com/document/143680669/Collier-Mark-Bill-Manley-1998-How-to-R ead-Egyptian-Hieroglyphs.

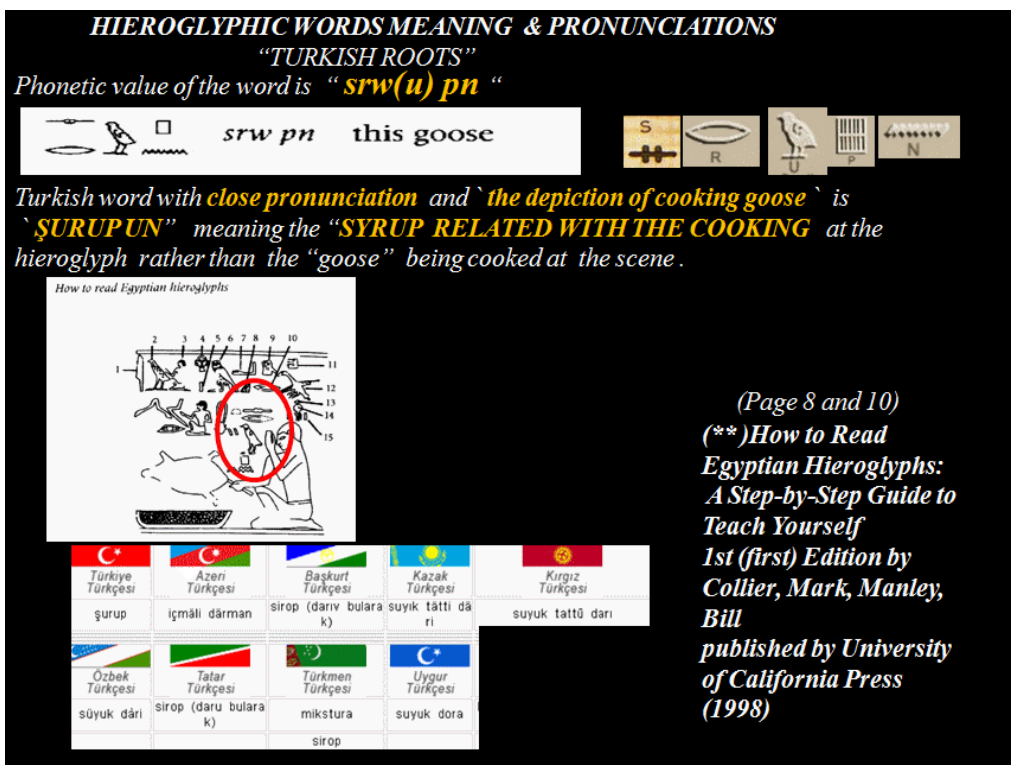

Picture 68. http://tureng.com/tr/turkce-ingilizce/\%C5\%9Furup Şurup

http://www.tdk.gov.tr/index.php?option=com_lehceler\&arama=lehceler\&guid=TDK.LH C.59806e6fe90526.22133333

Turkish Dialects official web page for TÜRK DİL KURUMU

Mark C., Bill M. How to read Egyptian Hieroglyphs, British Museum Press 1998 ISBN 0714119105

https://www.scribd.com/document/143680669/Collier-Mark-Bill-Manley-1998-How-to-R ead-Egyptian-Hieroglyphs. 


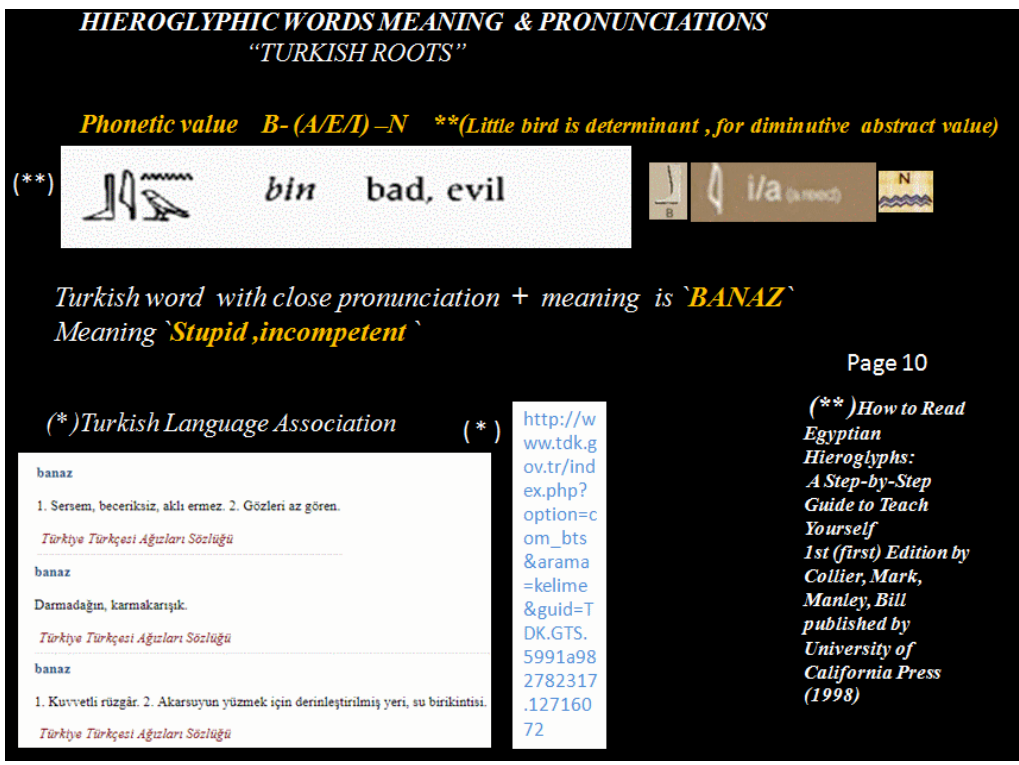

Picture 69. http://tureng.com/tr/turkce-ingilizce/ba\%C4\%9Fnaz Banaz (Bağnaz) http://www.tdk.gov.tr/index.php?option=com_lehceler\&arama=lehceler\&guid=TDK.LH C.59806e6fe90526.22133333

Turkish Dialects official web page for TÜRK DİL KURUMU

Mark C., Bill M. How to read Egyptian Hieroglyphs, British Museum Press 1998 ISBN 0714119105

https://www.scribd.com/document/143680669/Collier-Mark-Bill-Manley-1998-How-to-R ead-Egyptian-Hieroglyphs.

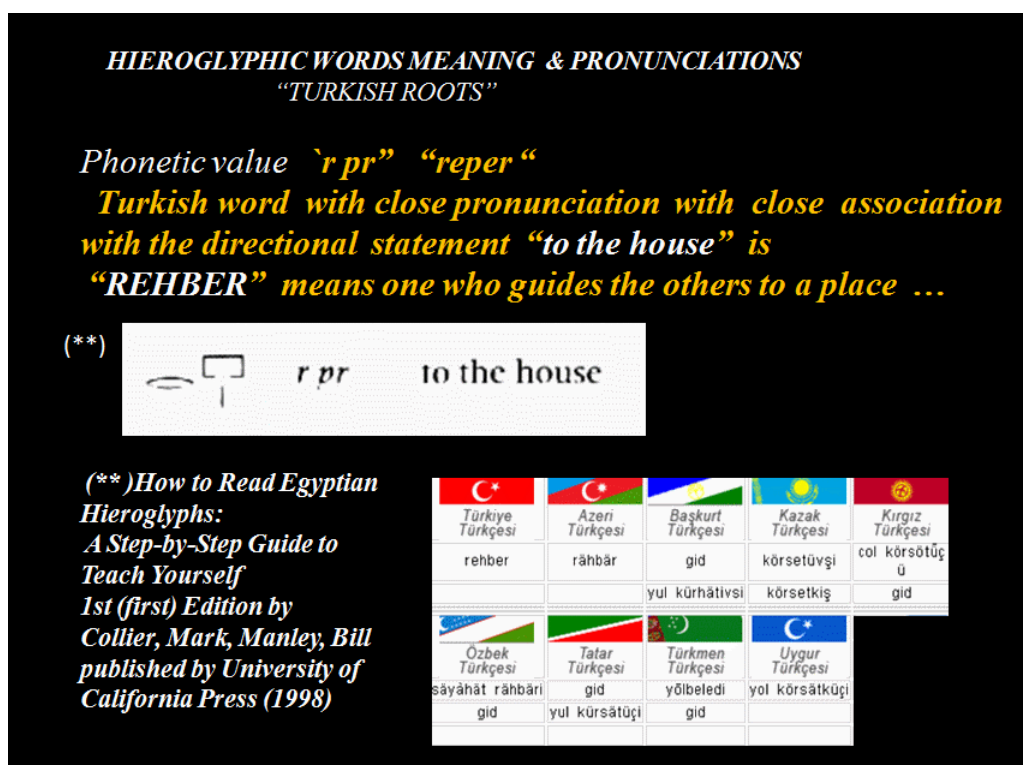

Picture 70. http://tureng.com/tr/turkce-ingilizce/rehber Rehber

http://www.tdk.gov.tr/index.php?option=com_lehceler\&arama=lehceler\&guid=TDK.LH C.59806e6fe90526.22133333

Turkish Dialects official web page for TÜRK DİL KURUMU

Mark C., Bill M. How to read Egyptian Hieroglyphs, British Museum Press 1998 ISBN 0714119105

https://www.scribd.com/document/143680669/Collier-Mark-Bill-Manley-1998-How-to-R ead-Egyptian-Hieroglyphs. 


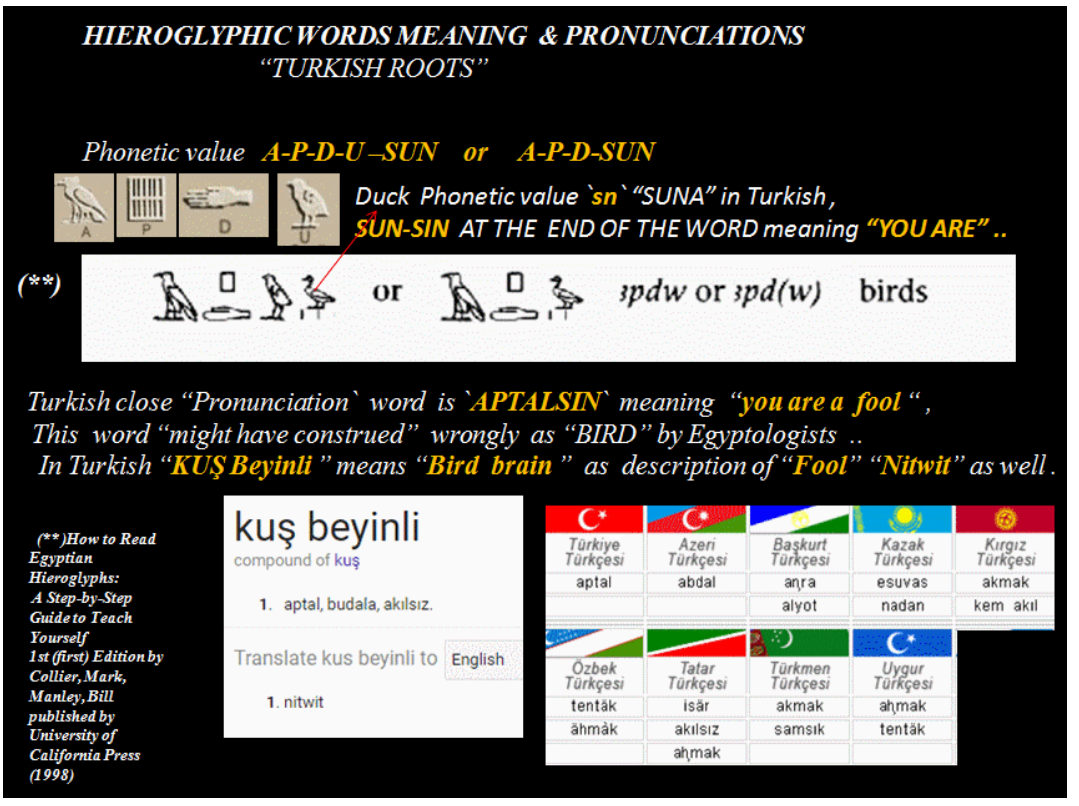

Picture 71. http://turkce-ingilizce.cevirsozluk.com/14652187-kus-beyinli Kuş Beyinli http://www.tdk.gov.tr/index.php?option=com_lehceler\&arama=lehceler\&guid=TDK.LH C.59806e6fe90526.22133333

Turkish Dialects official web page for TÜRK DİL KURUMU

Mark C., Bill M. How to read Egyptian Hieroglyphs, British Museum Press 1998 ISBN 0714119105

https://www.scribd.com/document/143680669/Collier-Mark-Bill-Manley-1998-How-to-R ead-Egyptian-Hieroglyphs.

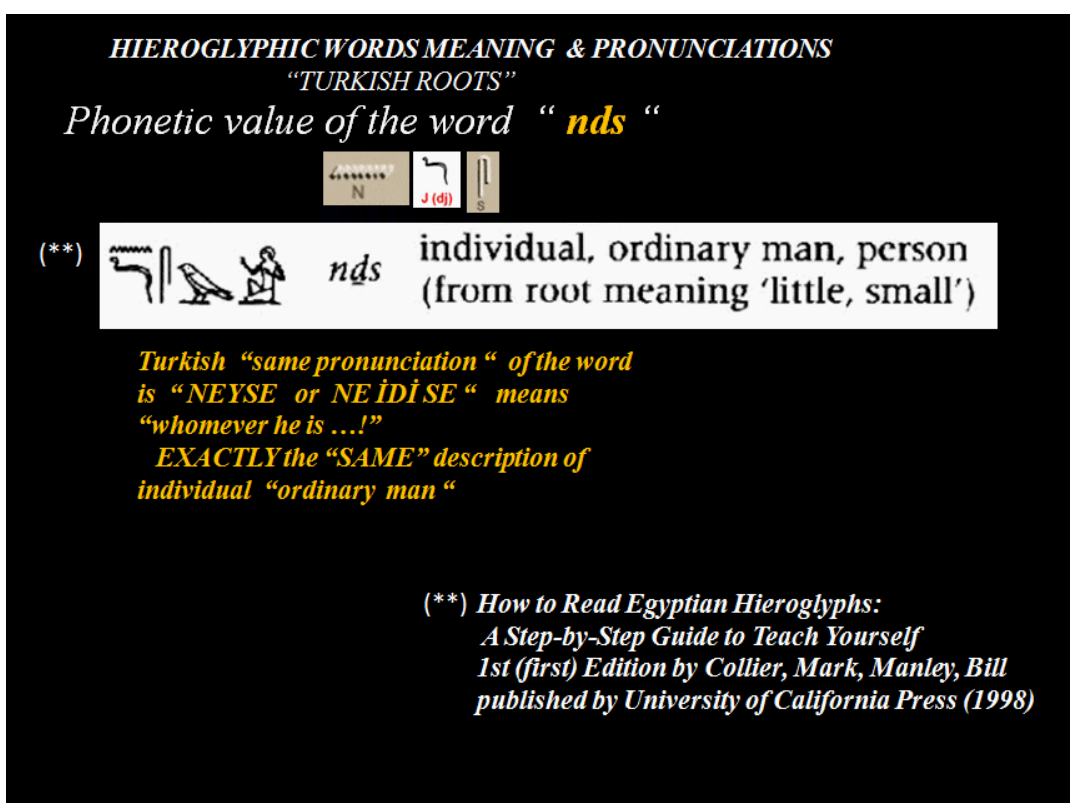

Picture 72

http://tdk.gov.tr/index.php?option=com_content\&view=article\&id=217:ek-fiilin-yazilisi

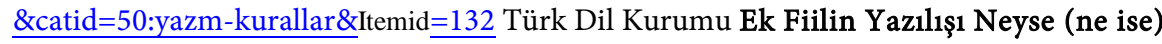
https://www.scribd.com/document/143680669/Collier-Mark-Bill-Manley-1998-How-to-R ead-Egyptian-Hieroglyphs Mark C., Bill M. How to read Egyptian Hieroglyphs, British Museum Press 1998 ISBN 0714119105. 


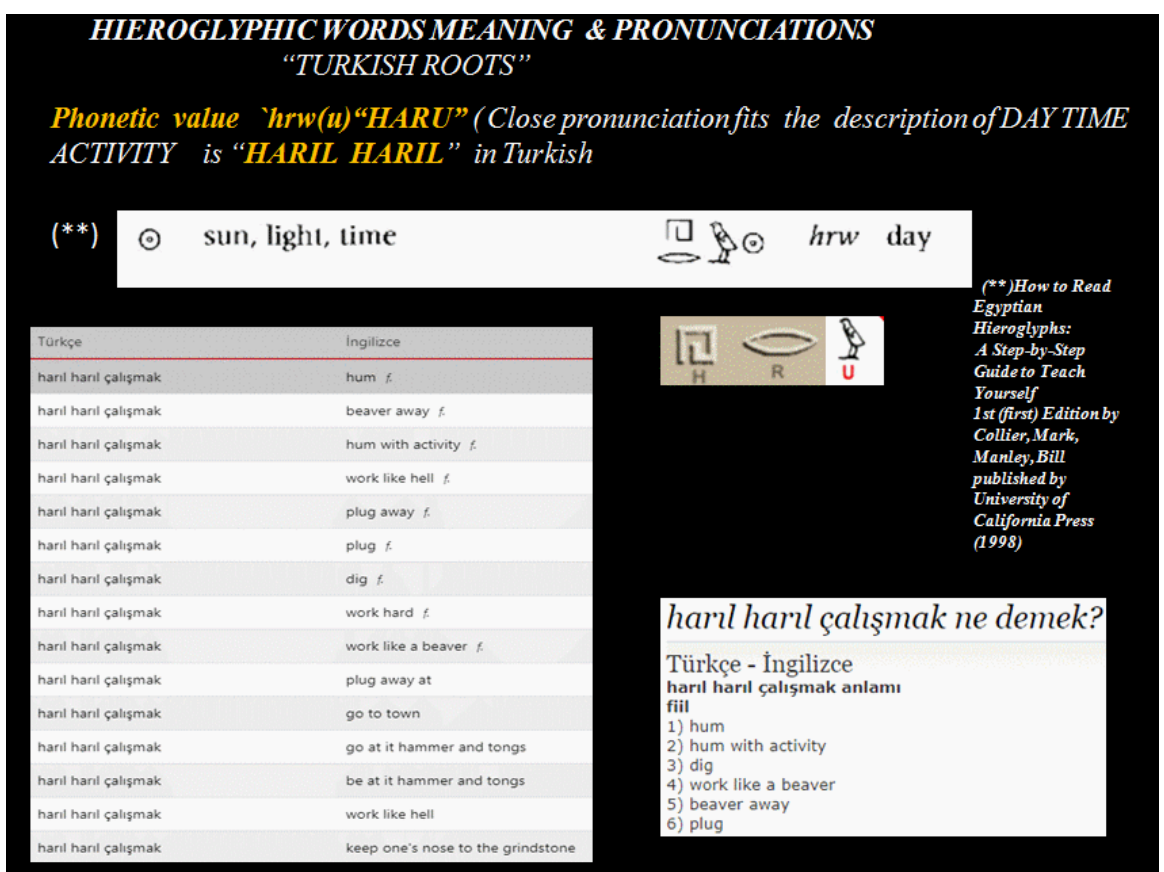

Picture 73.

http://www.nedirnedemek.com/har\%C4\%B1l-har\%C4\%B1l-\%C3\%A7al\%C4\%B1\%C5\%9 Fmak-nedir-har\%C4\%B1l-har\%C4\%B11-\%C3\%A7al\%C4\%B1\%C5\%9Fmak-ne-demek Harıl harıl çalışmak.

\section{SAMPLES FROM GARDINER'S SIGNLIST}

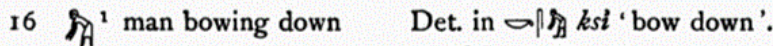
IEx, D.elB. 7o.

kasilmak

(nsz) 1. Kasma iş̣ yapıılmak. 2. tup Büzülüp toplanmak, büzüşmek, takallüs etmek. 3. mec. Büyüklenmek, kurumlanmak, gurưlanmak: "Ben Namık Kemal'im, koskoca vatan sairiyim, deyip de kastlmaz hiçbir zaman. "-N. Cumalı.

Güncel Türkçe Sözlük

\section{Phonetic value is "ksi" TO BOW DOWN by Egyptologists . Turkish "exact word" is "KASILMAK"}

Türk Dil Kurumu (Turkish Language Association web page)

http://www.tdk.gov.tr/index.php?option=com bts\&arama=kelime\&guid=TDK.GTS.59901ae8ee5da4.07234014

Picture 74. http://tureng.com/tr/turkce-ingilizce/kas\%C4\%B1lmak Kasılmak http://www.tdk.gov.tr/index.php?option=com_lehceler\&arama=lehceler\&guid=TDK.LH C.59806e6fe90526.22133333

Turkish Dialects official web page for TÜRK DİL KURUMU. 


\section{7 âd child sitting (on lap) ए4 $5 r i$ 'child';}

From left to right since the child is looking to the left

Phonetic values SH (S) (Rectangular pool with lotus flowers) +

$R$ (open mouth phonetic value)

Single REED FLOWER (can be read as $\dot{I}-E-A$ )

Phonetic value $S H(S)+R+\dot{I}$

Turkish word with very close pronunciation is "ŞIRIN" means CUTE CHILD

PS: Notice the 'root of the word' is 'FARSI' NOT TURKISH in other words it had entered the Turkish vocabulary Long after the Farsi word ' şiRiN 'is created from 'SumerianAkkadian-Assyrian 'roots in history. So it means the HIEROGLYPHICSIGN AS WELLAS PHONETIC VALUE POSSIBLY CREATED LATE IN HISTORYOF EGYPT

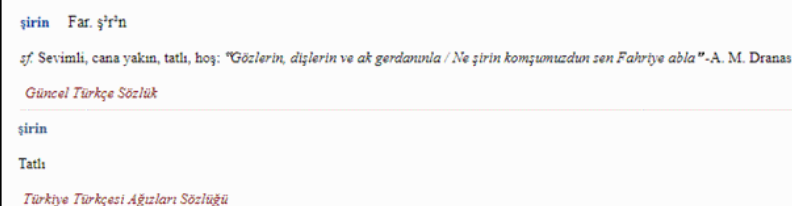

Picture 75. http://tureng.com/tr/turkce-ingilizce/\%C5\%9Firin Şirin

http://www.tdk.gov.tr/index.php?option=com_lehceler\&arama=lehceler\&guid=TDK.LH C.59806e6fe90526.22133333

Turkish Dialects official web page for TÜRK DİL KURUMU.

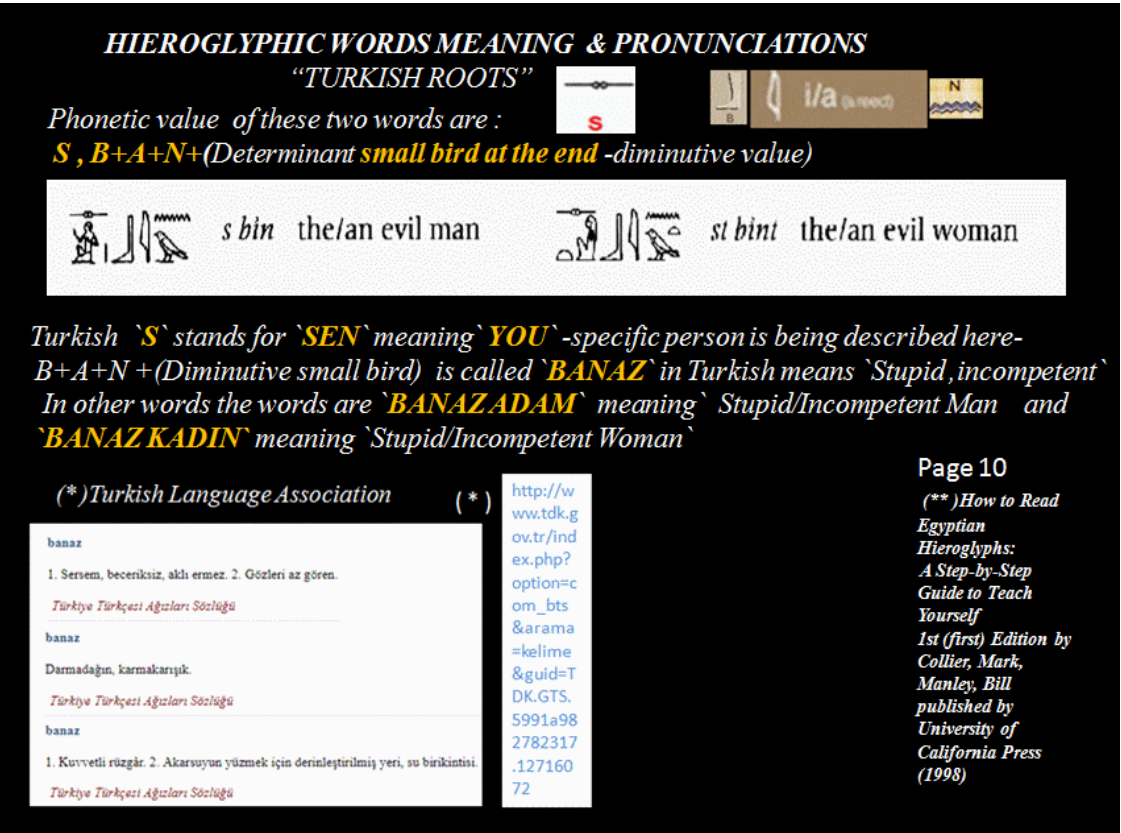

Picture 76. http://tureng.com/tr/turkce-ingilizce/ba\%C4\%9Fnaz Banaz (Bağnaz)

Mark C., Bill M. How to read Egyptian Hieroglyphs, British Museum Press 1998 ISBN 0714119105

https://www.scribd.com/document/143680669/Collier-Mark-Bill-Manley-1998-How-to-R ead-Egyptian-Hieroglyphs

http://www.tdk.gov.tr/index.php?option=com_lehceler\&arama=lehceler\&guid=TDK.LH C.59806e6fe90526.22133333

Turkish Dialects official web page for TÜRK DİL KURUMU. 


\section{SAMPLES FROM GARDINER'S SIGNLIST}

17* child in sitting posture, Adapted from hieratic, ${ }^{1}$ where it replaces $\mathrm{A}_{3}$, ex, arms hanging down hmsi 'sit', or $\mathrm{A}_{17}$, ex. ' Molt. Pal. i, no. 3t. 'P. Kah. 6, 5. ' $\mathrm{Hat}$-Nub 18, 5 .

\section{7, ex.}

Phonetic value is "msw" by Egyptologists. Read as "MES + U(W)

\begin{tabular}{|c|c|c|c|}
\hline 84 & $\pi$ & mes $\mathbb{A}$ & $\begin{array}{l}\text { fly-flapper made of the tails of } \\
\text { foxes. }\end{array}$ \\
\hline
\end{tabular}

HAPPY so the sign is the depiction of a

"HAPPY CHILD"

PS: Notice the 'root of the word' is 'ARABIC' NOT TURKISH in other words it had entered the

Turkish vocabulary Long after the Arabic word-verb 'Mesut' is created from 'Sumerian-Akkadian-Assyrian 'roots So the HIEROGLYPHIC SIGN AS WELL AS PHONETIC VALUE POSSIBLY CREATED LATE IN HISTORY OF EGYPT

\begin{tabular}{|c|c|}
\hline 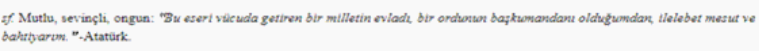 & $\begin{array}{l}\text { http://www.tdk.gov.tr/in } \\
\text { dex.php?option=com_bts }\end{array}$ \\
\hline Guncel Tarkice So:itit & \&arama=kelime \&guid=TD \\
\hline Iesut & K.GTS.599023bcea21b3.1 \\
\hline$<$ Ar mes vid mesut; Mesut & 7438548 \\
\hline
\end{tabular}

Picture 77. http://tureng.com/tr/turkce-ingilizce/mesut Mesut

http://www.tdk.gov.tr/index.php?option=com_lehceler\&arama=lehceler\&guid=TDK.LH C.59806e6fe90526.22133333

Turkish Dialects official web page for TÜRK DİL KURUMU.

3 WORDS IN TURKISH HAS VERYCLOSE “PRONUNCLATIONS” BUT DIFFERENT MEANINGS (These are from Wikipedia 'Determinatives'section at this link NEFER - NEFES - NEFIS

WE CAN CLEARLY SEE THIS "EGYPTIAN HIEROGLYPHS" WITH USE OF

"DETERMINATIVES" at the end ....

NEFER "Means" young foot soldier ,NEFES “Means" BREATH , NEFIS “Extraordinary, Beautiful, Delicious"

T I I nfw ( $w$ and the three strokes are the marks of the plural: [literally] "the beautiful young

13 i people", that is to say, the young military recruits.

Q The word has a vouna-person determinative symbol 5 is which is the determinative

Phonetic values NEFER + Ufak (means, young) with 3 Strokes (plural) Turkish translation "Genç (Ufak) Neferler , meaning young recruits

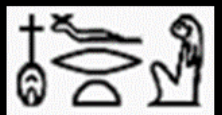

nff.t (t. is here the suffix thatforms the feminine): meaning "the nubile young

woman", with as the determinative indicating a woman

Phonetic values $N E F E R+F+R+T$ and Woman

The clue is the $F$ (Horned viper phonetic value " $F$ "originates

from Turkish-Fikardamak sound of the viper as well as

"Fingirdek" "in figurative speech " meaning is "coquettish-coquetry girl

Turkish word is FİNGÍRDEK Cilvelenmek FİNGİRDEK

also means, moving body parts too noticeable to attract attention

So this word is the "Description of Beautiful attractive woman

Picture 78. https://en.wikipedia.org/wiki/Egyptian_hieroglyphs Egyptian Hieroglyphs http://tureng.com/tr/turkce-ingilizce/nefer Nefer http://tureng.com/tr/turkce-ingilizce/nefes Nefes http://tureng.com/tr/turkce-ingilizce/nefis Nefis

Re: Picture 33(F phonetic value Horned Viper)

http://tureng.com/tr/turkce-ingilizce/fingirdemek Fingirdemek

Re: Picture 18 (U(w) phonetic value -quail chick-)

http://tureng.com/tr/turkce-ingilizce/ufak Ufak. 


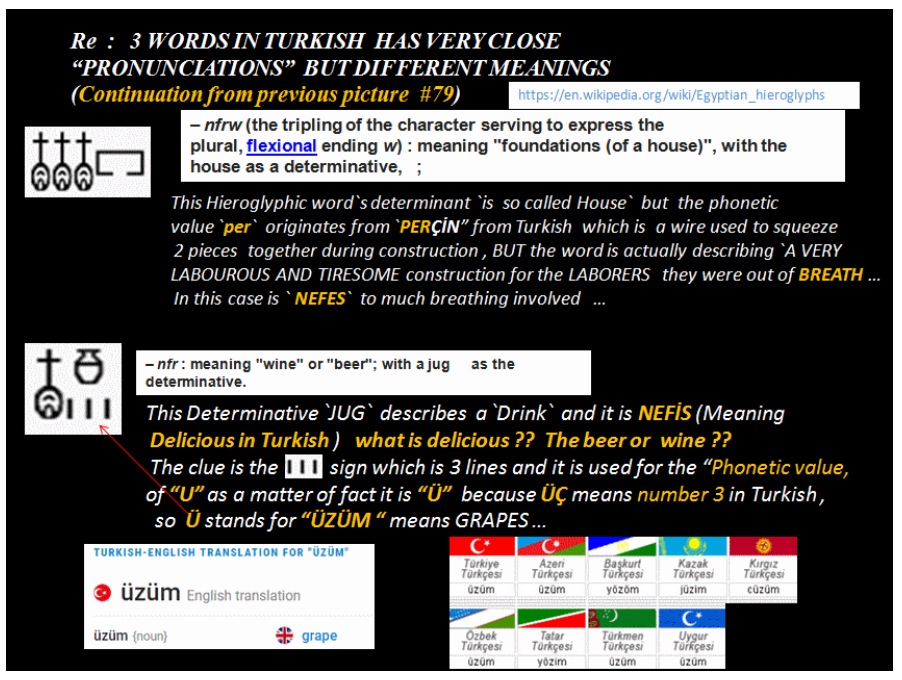

Picture 79. https://en.wikipedia.org/wiki/Egyptian_hieroglyphs Egyptian Hieroglyphs http://tureng.com/tr/turkce-ingilizce/\%C3\%BCz\%C3\%BCm Üzüm http://tureng.com/tr/turkce-ingilizce/nefer Nefer http://tureng.com/tr/turkce-ingilizce/nefes Nefes http://tureng.com/tr/turkce-ingilizce/nefis Nefis http://www.tdk.gov.tr/index.php?option=com_lehceler\&arama=lehceler\&guid=TDK.LH C.59806e6fe90526.22133333

Turkish Dialects official web page for TÜRK DİL KURUMU

Re: Picture 35 (for Per-pr phonetic value of the sign)

http://tureng.com/tr/turkce-ingilizce/per\%C3\%A7in Perçin.

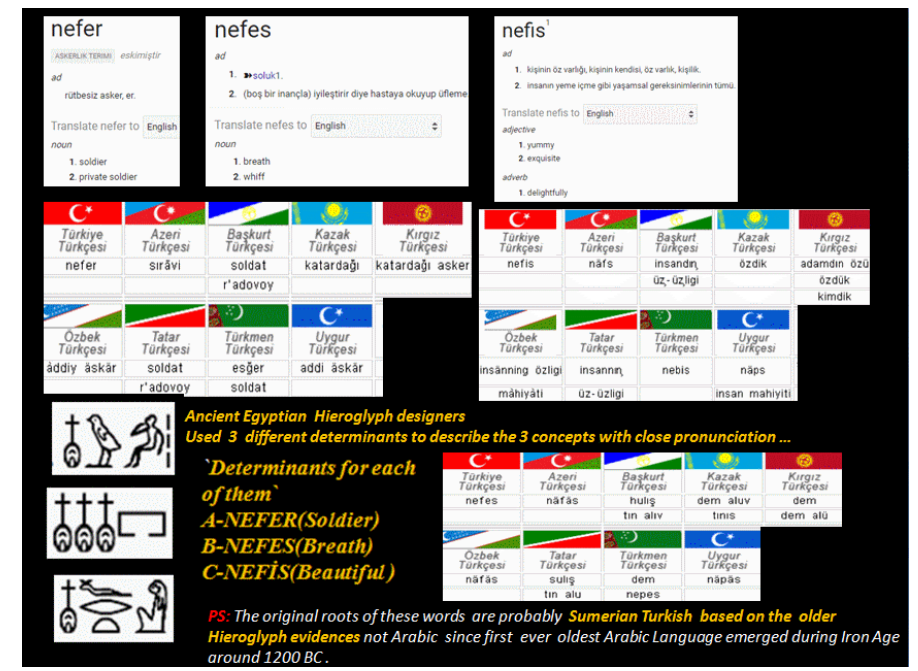

Picture 80. http://tureng.com/tr/turkce-ingilizce/nefer Nefer http://tureng.com/tr/turkce-ingilizce/nefes Nefes http://tureng.com/tr/turkce-ingilizce/nefis Nefis http://www.tdk.gov.tr/index.php?option=com_lehceler\&arama=lehceler\&guid=TDK.LH C.59806e6fe90526.22133333

Turkish Dialects official web page for TÜRK DİL KURUMU

Re: Supplement picture 33(F-Phonetic value Horned Viper)

http://tureng.com/tr/turkce-ingilizce/fingirdemek Fingirdemek

Re: Supplement picture 18 (U(w) phonetic value)

http://tureng.com/tr/turkce-ingilizce/ufak Ufak. 